九州大学学術情報リポジトリ

Kyushu University Institutional Repository

\title{
Evolution of Lepidolina multiseptata (Permian Foraminifer) in East Asia
}

Ozawa, Tomowo

Faculty of Science, Kyushu University

https://doi.org/10.5109/1544173

出版情報：九州大學理學部紀要：Series D, Geology. 23 (2)，pp.117-164，1975-11-25. Faculty of Science, Kyushu University バージョン：

権利関係 : 
Mem. Fac. Sci., Kyushu Univ., Ser. D, Geol., Vol. XXIII, No. 2, pp. 117-164, text-figs. 1-13, pls. 22-26, November 25, 1975

\title{
Evolution of Lepidolina multiseptata (Permian Foraminifer) in East Asia
}

\author{
Tomowo OzAwa
}

\begin{abstract}
This paper gives an account of the morphologic variation and evolution in a Permian verbeekinoid foraminifer, Lepidolina multiseptata (DEPRAT, 1912), which occurs mainly in East Asia embracing Southeast Asia, South China and the Japanese Islands. More than 3000 specimens of 34 samples taken carefully from several stratigraphic horizons of the Middle to Upper Permian of this wide geographic area were investigated for the purpose of examining intraand interpopulational variation and chronologic shift in shell characters. The continuous variation has been analyzed by means of biometric techniques and quantitatively described. Marked individual variation and slight geographic variation are recognized in the species. These phenomena are interpreted from various points of view, such as life cycle, mode of dispersal and habitat environments of the foraminifer. The phyletic evolution with one-way trend shown by this foraminifer is described in detail and briefly discussed. This paper also includes geographic and stratigraphic distribution, paleoecology and taxonomic notes on Lepidolina multiseptata.
\end{abstract}

\section{Contents}

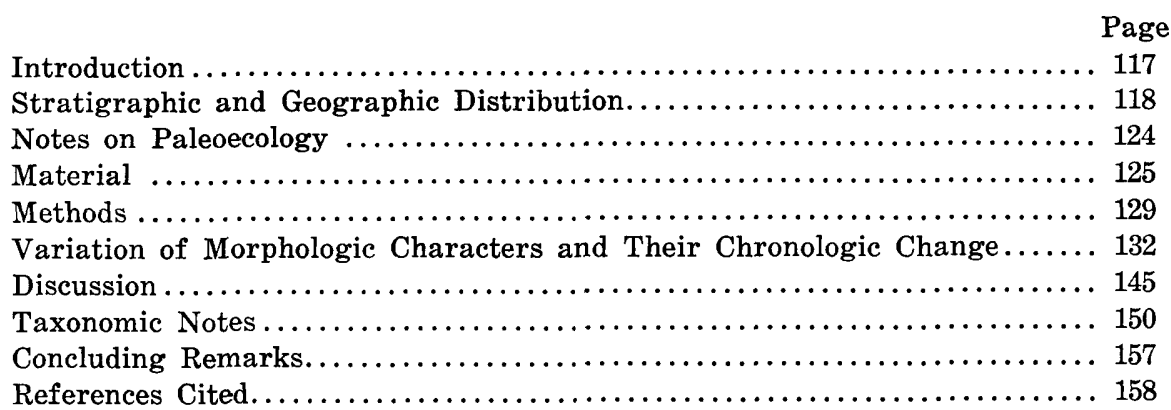

\section{Introduction}

Modern taxonomy has been devoted to the study of intra- and interpopulational variation of species, because the natural unit in organisms is not the individual but the breeding population. The study of infraspecific variation is indispensable also in paleontology which focuses on the interpretation of evolutionary development of ancient life. The study of variation and its relation to the mechanism of evolu-

Manuscript received May 29, 1975. 
tionary change in fossil organisms has been in difficulties because of the paucity of suitable materials which permit precise analyses of evolutionary development. Studies of the Upper Cretaceous sea urchin Micraster in Europe and the Liassic oysters Gryphaea in England are exceptionally good examples which have shown evolutionary development in successive lineages as the shift of population in time. The evolution even in these celebrated cases is not yet confirmed in the whole distribution area of the species, but as a phenomenon in a stratigraphic section and/or in a limited geographic area.

The fusulinid foraminifers to which Lepidolina multiseptata belongs, have, like Eocene Nummulites and Recent Alveolinella, large and complex shells and they are a dominant group of late Paleozoic foraminifera. They provide paleontology with good material for following the course of evolution at an infraspecific level, because their shells are well preserved in limestone as one of the main rock builders. Among others, Lepidolina multiseptata (DEPRAT) occuring from the Middle to Upper Permian of the circum-Pacific region, is a species of special interest from the viewpoint of evolutionary paleontology. This species has been accepted as one of the most reliable guide fossils of the Middle to Upper Permian of this region. It is widely distributed geographically and stratigraphically, and permits the development of a detailed chronology of the course of evolution. I present a result of the study of evolution of Lepidolina multiseptata based on the examination of a large number of collections from various stratigraphic horizons of an extensive geographic area in East Asia.

\section{Stratigraphic and Geographic Distribution}

Lepidolina multiseptata (DEPRAT) has been dealt with by many biostratigraphers as a useful guide fossil for interregional correlation of the Middle to Upper Permian System in the western Pacific region. Intensive biostratigraphic studies of the Middle and Upper Permian since the second decade of this century have provided us very rich information on the stratigraphic and geographic distribution of the species. As far as we know, Lepidolina asiatica (IsHII, 1966), which has intermediate characters between Colania douvillei (OzAWA) and Lepidolina multiseptata (s.s.) may be the most primitive and oldest member of the Lepidolina multiseptata lineage. It occurs in the middle Middle Permian limestone of Southeast Asia and the Japanese Islands (IsHII, 1966; IsHII et al., 1969; OzAWA, in this paper). In the upper Middle Permian to the lower Upper Permian age, Lepidolina multiseptata prospered in the Eastern and Southeast Asia, and spread their distribution. It migrated to the North Island of New Zealand (HORNIBRook, 1951) through the area including the Malaya peninsula and Sunda Arch, and also to British Columbia in the Pacific Northwest of North America through the Far East (SKINNER and WILDE, 1966). As the clastic sedimentary facies became predominant and accordingly the area of neritic carbonate sedimentary facies became narrow in the lower Upper Permian age, Lepidolina multiseptata rapidly reduced its distribution. As a relict fauna of the verbeekinoid foraminifera, it is known only from some small limestone bodies in the clastic sedimentary facies in Eastern Asia embracing the Japanese Islands and Sikhote-Alin area (OzAWA, 1970, fig. 2). It became extinct at the end of the lower Upper Permian age. The geographic and stratigraphic distribution of the species is summarized in Figs. 1 and 2. As may be understood from the figure, the center of distribution of the Lepidolina multi- 


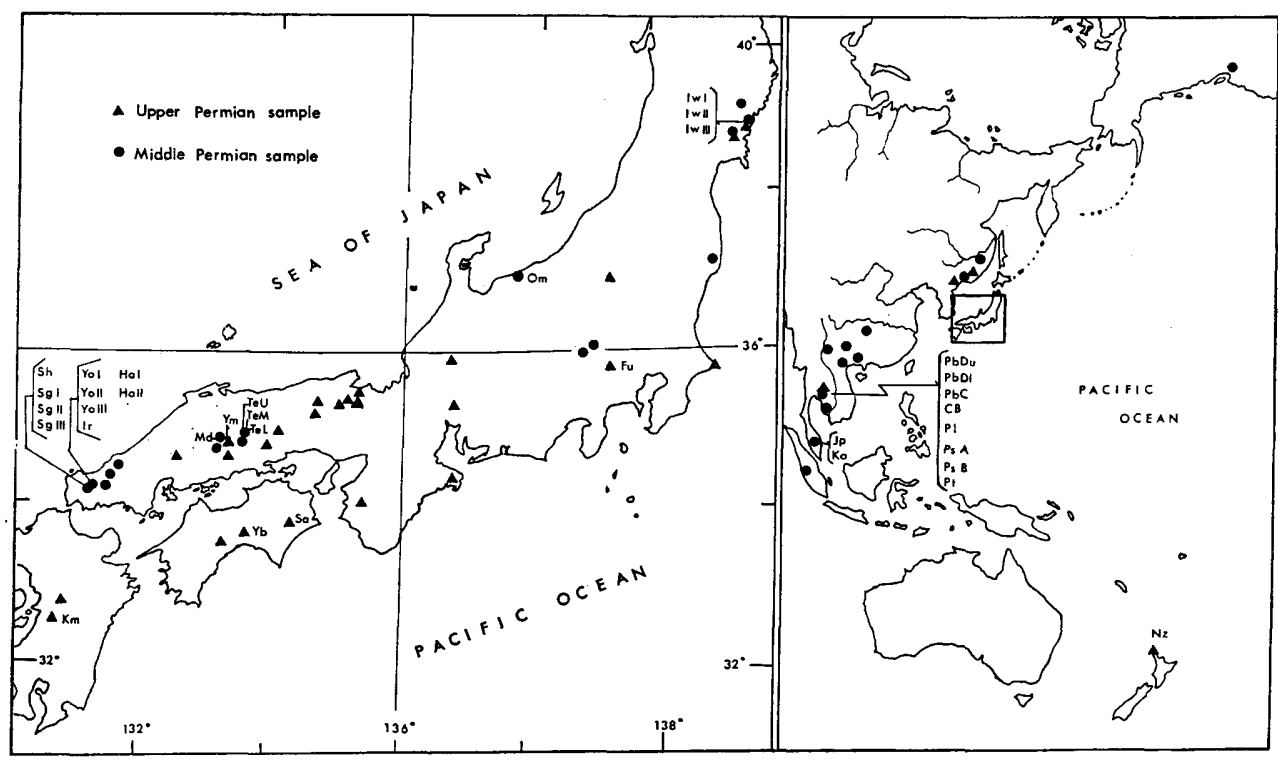

Fig. 1. Geographic and stratigraphic distribution and sample localities of Lepidolina multiseptata.

septata lineage has been in the region covering the Japanese Islands, South China and Southeast Asia. There is a large number of localities in this region. For instance, more than forty localities are known in the Japanese Islands (Fig. 1). Among these localities the areas mentioned below are particularly important for the present study, because the species occur at several horizons in the limestone sequence.

a) Sisophon-Battambang area, West Cambodia. The limestone hills in the western part of Cambodia are especially rich in marine invertebrate fossils and provide a good geologic section for the Middle to Upper Permian in Southeast Asia. DePrat (1912, 1913), GUbler (1935), SAURIN (1959), Fontaine (1967), IshiI (1966) and ISHII et al. (1969) studied the biostratigraphy of the Permian limestone of West Cambodia. According to the last two papers, the following four fusulinid zones are distinguished in the Sisophon and Battambang limestones in descending order.

Member D (30-100 m).... Lepidolina multiseptata Zone

Member C $(60-8 \mathrm{~m})$...... Lepidolina multiseptata-Sumatrina annae longis-

Member B (40 m) sima Zone

Upper half.......Lepidolina asiatica-Sumatrina annae longissima Zone

Lower half ........Pseudodoliolina pseudolepida-Pseudofusulina ambigua pursatensis Zone

In this sequence Lepidolina multiseptata occurs at four different horizons. According to ISHII (1966), the shell size of the species becomes larger as the stratigraphic horizon becomes higher and Lepidolina asiatica from the upper part of Member B is a transitional species between Colania douvillei and Lepidolina multiseptata.

Eight samples from the four different horizons, upper half of B Member 
(sample $C B$ ), C Member (sample $P b C$ ), lower part of D Member (samples $P b D l$, $P t$ and $P s B$ ) and upper part of $\mathrm{D}$ Member (samples $P b D u, P l$ and $P s A$ ) are studied in this paper.

b) Maukou limestone, South China. The Maukow, Wuchiaping and Chianghsin limestones in Kwangsi, Kueichow and Szechuan provide a standard geologic section of the Middle and Upper Permian of South China. According to Sheng (1963), in the uppermost part of the Maukou limestone, Lepidolina multiseptata (=Lepidolina gubleri) occurs at $20 \mathrm{~m}$ above the horizon where Colania douvillei and Colania kwangsiana occur. The Wuchiaping limestone characterized by the Codonofusiella faunule unconformably overlies the Lepidolina multiseptata limestone.

c) Akiyoshi limestone, western Chugoku, Japan. In the Inner Zone of Southwest Japan there are several large isolated limestone masses of Permian and Carboniferous ages. They are, from northeast to southwest, Omi, Atetsu, Taishaku, Oga, Handa and Akiyoshi limestones. The Akiyoshi limestone in Yamaguchi Prefecture is one of the classical areas of the Upper Paleozoic stratigraphy in Japan. Since Y. OzAWA (1923)'s pioneer work, many biostratigraphers have dealt with the zonation of the limestone using invertebrate fossils. The uppermost part of the Akiyoshi limestone is characterized by a prolific occurrence of Lepidolina multiseptata "shiraiwensis" (OzAWA). TORIYAMA (1958) set up the Lepidolina shiraiwensis zone as the highest fusulininan zone of the limestone. According to him, the zone directly overlies both the Colania douvillei zone and the lower subzone of the so-called Neoschwagerina Zone. For the purpose of the present study, detailed stratigraphic work was undertaken to know the stratigraphic horizons of Lepidolina multiseptata "shiraiwensis". The species occurs from at least four horizons in the limestone sequences at Shigeyasu and Yobara in Mine City, Yamaguchi Prefecture. The lowest horizon is situated just above the zone with Colania douvillei and Neoschwagerina margaritae. Ten samples (SgI, Sg II, Sg III, Yo I, Yo II, Yo III, Ha I, $\mathrm{Ha} I I$, Sh and $I r$ ) from four horizons are studied in this paper. Judging from shell characters, the topotype specimens of Yabeina shiraiwensis Ozawa from Shiraiwa may represent a sample from the third horizon from the base. Shell and proloculus size gradually becomes larger as the sequence goes upward.

d) Atetsu limestone, central Chugoku, Japan. NogAmi (1961) and SADA $(1960,1965)$ studied the Permian and Carboniferous biostratigraphy of this limestone. The Middle and Upper Permian of the Atetsu limestone and the overlying Terauchi formation is subdivided by Nogami as follows:

Terauchi form. Lepidolina shiraiwensis Zone $\left(m \mathrm{P}_{2}\right)$

Lepidolina shiraiwensis subzone $\left(m \mathrm{P}_{2-\beta}\right)$

Lepidolina shiraiwensis- $L$. sp. A subzone $\left(m \mathrm{P}_{2-\alpha}\right)$

Atetsu ls. Colania douvillei-Neoschwagerina margaritae Zone $\left(m \mathrm{P}_{1}\right)$

Colania douvillei-N. margaritae subzone $\left(m \mathrm{P}_{1-\beta}\right)$

Neoschwagerina craticulifera subzone $\left(m \mathrm{P}_{1-\alpha}\right)$

Lepidolina shiraiwensis first appears in the uppermost part of the Atetsu limestone and abundantly occurs in limestone lenses of the Terauchi formation. According to NOGAMI (1961, p. 214-217), the shell and proloculus size of the species from the $m \mathrm{P}_{2-\alpha}$ zone begins to become larger, and the septa and septula gradually increase in number in ascending sequence. Thus Lepidolina shiraiwensis from the upper subzone $\left(m \mathrm{P}_{2-\beta}\right)$ of this limestone has a much larger shell and proloculus and is much advanced in septural and septal features, compared with the topotype of 
Yabeina shiraiwensis from Shiraiwa in Akiyoshi. Shell characters no longer closely resemble those from the lower subzone. As IsHII (1966, p. 37) noticed, specimens from the upper subzone of Lepidolina shiraiwensis zone in Atetsu have intermediate shell features between the topotypes of Lepidolina shiraiwensis (OzAWA) and those of L. multiseptata (DEPRAT).

Three samples ( $T e l, T e M$ and $T e U$ ) from the lower and upper subzones of NoGAMI's Lepidolina multiseptata Zone are studied in this paper.

e) Taishaku limestone, central Chugoku, west Japan. Lepidolina multiseptata from the Yasumoto formation (SADA and YoKoYAMA, 1966) in the Taishaku limestone plateau in Hiroshima Prefecture, $50 \mathrm{Km}$ west of the Atetsu limestone resembles Lepidolina shiraiwensis from the upper subzone of L. shiraiwensis Zone of the Atetsu limestone. The Yasumoto sample $(\mathrm{Ym})$ comes from the highest stratigraphic horizon of Lepidolina multiseptata in limestone plateau in the Inner Zone of Southwest Japan and is closely similar to that from the lowest horizon of the Kuma formation mentioned below. Lepidolina shiraiwensis (OzAWA) occurs from the Maedani formation in the Taishaku area (sample $M d$ ).

f) Kuma formation, southern Kyushu, Japan. The Kuma formation, a reference section of the uppermost stratigraphic division, the Kuma series, of the Permian of Japan, is typically exposed in the upper course of the Hikawa river in Yatsushiro-gun, Kumamoto Prefecture (KANMERA, 1953, 1954). It is $900 \mathrm{~m}$ in thickness, and consists of conglomerate, sandstone and black shale, with black impure limestone at four horizons. In the limestone of the lowest horizon Lepidolina multiseptata (=L. yasubaensis) occurs with some schwagerinids. "Lepidolina yasubaensis" from this horizon, as pointed out by KANMERA (1954, p. 19) and others is closely similar in shell characters to Lepidolina shiraiwensis from the upper subzone of Lepidolina shiraiwensis zone in the Atetsu, Taishaku and Akiyoshi limestones. The limestone of the middle horizon provides us with the latest Lepidolina fauna (sample $\mathrm{Km}$ ). Lepidolina multiseptata ( $=L$. gubleri) occurs abundantly in association with Lepidolina kumaensis KANMERA and many other foraminifera including species of Codonofusiella, Dunbarula and Colaniella (see list in p. 129). I have recently found Reichelina sp., Codonofusiella sp. and Nodosaria mirabilic LIPINA as characteristic of the limestone of the uppermost horizon of the Kuma formation, although no foraminiferal species were reported from it by previous authors. The Upper Permian formations which closely resemble the Kuma in lithology and faunal assemblage are developed in other areas of the Outer Zone of Southwest Japan, the Maizuru Zone and the Kitakami massif.

g) Yasuba formation, central Shikoku, Japan. The Upper Permian Yasuba formation consists mainly of black mudstone and sandstone with conglomerate and limestone lenses. TorIYAMA (1942) set up Yabeina yasubaensis on the basis of the large neoschwagerinid specimens from the "conglomeratic" limestone of the formation. ISHII and NoGAMI (1962) restudied the topotypes and regarded this species as a synonym of Lepidolina multiseptata shiraiwensis (OzAWA). Specimens of Yabeina yasubaensis from Yasuba $(Y b)$ also closely resemble the specimens of Lepidolina multiseptata from the lowest fossil horizon of the Kuma formation in Southern Kyushu.

h) Haigyu formation, eastern Shikoku, Japan. Well preserved specimens of Lepidolina multiseptata occur in small limestone lenses of the Haigyu formation (sample $S a$ ). The close affinity in lithology and faunal elements between the Haigyu and Yasuba formation in Shikoku (SUYARI, 1961) and the Kuma formation in 
Kyushu (KANMERA, 1954) demonstrates that these three are of the same age.

i) Futamatao formation, southern Kwanto, Japan. The Futamatao formation consists chiefly of sandstone, black mudstone and conglomerate, with a limestone lens at the middle part of the formation. It is again a representative of the Kuma series. The limestone provides us with many well preserved specimens of Lepidolina multiseptata (sample $F u$ ).

j) Maizuru Belt, eastern Chugoku, Japan. The Upper Permian and the Lower Triassic sediments are well exposed in the Maizuru Belt in the Inner Zone of Southwest Japan. The Upper Permian Maizuru group (NAKazawa et al., 1954-1959, SHIMIZU, 1962) consists mainly of conglomerate, sandstone and black shale, with limestone lenses at some horizons. The stratigraphic sequence of the Permian in this belt is as follows:

Lower Triassic (pre-Owenitan) Yakuno group ..... fault, partly unconformity.....

Upper
Permian $\left(\begin{array}{l}\text { Gujo formation } \\ \text { Maizuru group }\end{array} \begin{array}{l}\text { Upper Maizuru formation } \\ \text { Middle Maizuru formation } \\ \text { Lower Maizuru formation }\end{array}\right.$

The Gujo formation is characterized by a bivalvian fauna, called the Gujo fauna. Species of Palaeofusulina, Reichelina and Colaniella occur in the limestone of the Upper Maizuru formation. Lepidolina kumaensis KANMERA, Lepidolina multiseptata (DEPRAT) and many other foraminifera are characteristic of impure limestone lenses of the Middle Maizuru and the lower half of the Upper Maizuru formation. It is noted that the Palaeofusulina-Reichelina faunule occurs just above the Lepidolina kumaensis-Lepidolina multiseptata limestone.

k) Omi limestone, central Japan. OzAwa (1922) proposed Yabeina hayasakai on the basis of a large neoschwagerinid with a large proloculus from the uppermost part of the Omi limestone. Sumatrina annae "longissima" DEPRAT, Verbeekina verbeeki (GEINITZ) and several other foraminifers are in association with Yabeina hayasakai. This foraminiferal assemblage is characteristic of the upper part of the Lepidolina shiraiwensis Zone in the Akiyoshi, Atetsu and Taishaku limestones. The Yabeina hayasakai horizon is undoubtedly correlated with the upper part of the Lepidolina shiraiwensis Zone of the limestone plateaux in the Inner Zone of Southwest Japan. As IsHII and NoGAMI (1962) suggested, Yabeina hayasakai may be a synonym of Lepidolina shiraiwensis.

1) Iwaizaki area, southern Kitakami massif, Northeast Japan.

The stratigraphy of the Permian of this area has been studied by many workers such as Mabuchi (1935), Hanzawa (1954) and Morikawa et al. (1958). MabUCHI subdivided the Iwaizaki limestone into the following zones in descending order.

V. Richthofenia japonica zone

IV. Lepidolina hayasakai zone

III. Verbeekina verbeeki zone

II. Waagenophyllum indicum zone

I. Monodiexodina matsubaishi zone.

HANZaWA (1954) found Neoschwagerina (=Colania) sp. from the Verbeekina verbeeki zone and the Waagenophyllum indicum zone. I also recognized a neoschwagerinid which may be identified with Colania douvillei (Ozawa) from the Verbeekina verbeeki zone of MABUCHI. Recently CHOI (1970) found Lepidolina kumaensis KANMERA and some other foraminifers in a limestone intercalated in the 


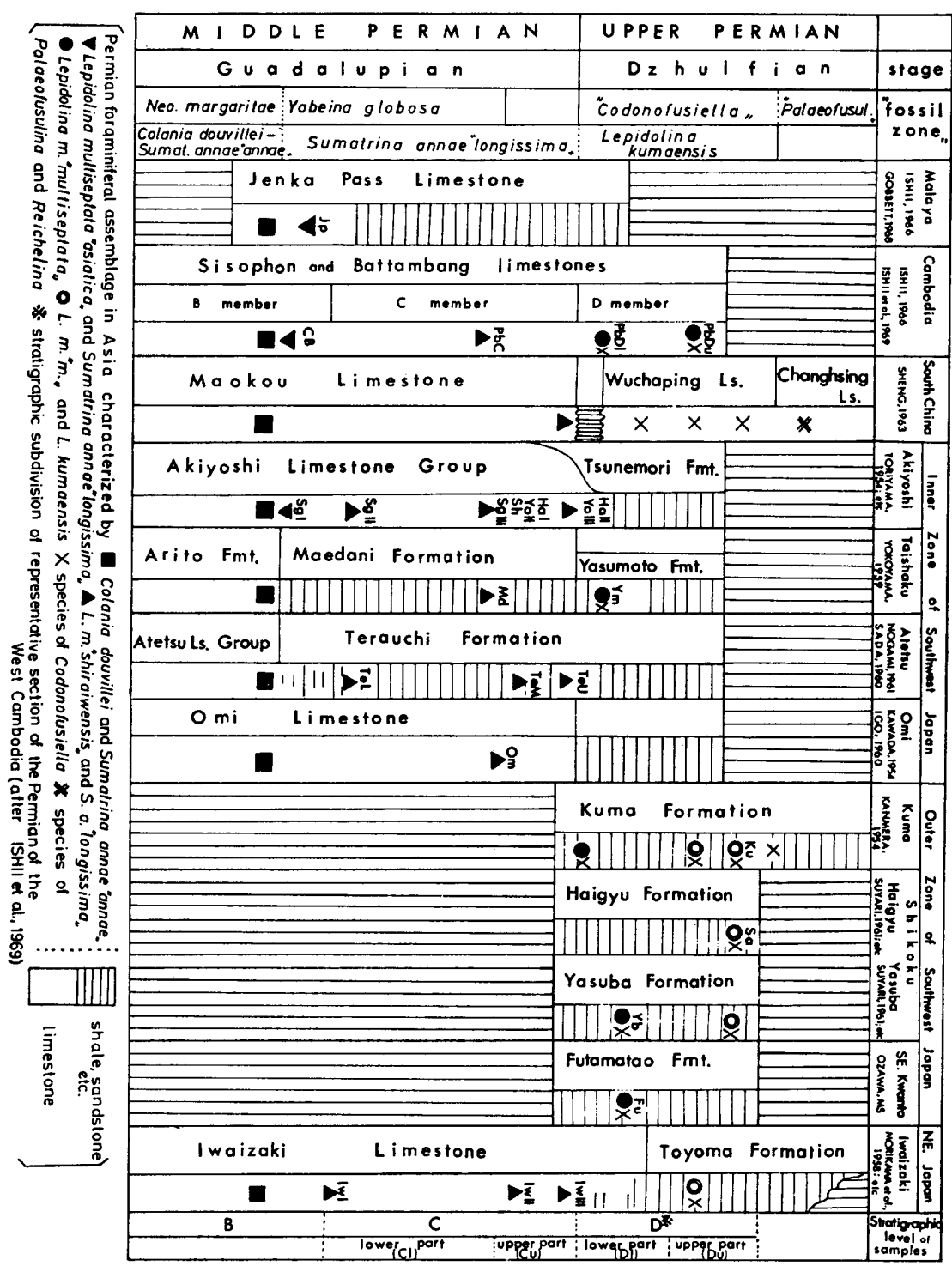

Fig. 2. Stratigraphic correlation of the upper part of the Permian of East Asia with indications of occurrence of the foraminiferal fauna and stratigraphic horizon of samples of Lepidolina multiseptata.

Toyoma clayslate. This limestone is stratigraphically assignable to the same level as or a higher level than the Richthofenia japonica zone of the Iwaizaki limestone.

Summarizing these facts, the Middle to Upper Permian rocks of the Iwaizaki area are characterized by the following foraminiferal faunules in descending order:

Lepidolina kumaensis faunule

Lepidolina multiseptata "shiraiwensis" faunule

Colania cf. douvillei-Verbeekina verbeeki faunule 
Lepidolina multiseptata "shiraiwensis" occurs at three different horizons (Iw $I, I w I I$ and $I w I I I$ ) in the e- and g-formations (MoRIKAWA et al., 1958) of the Iwaizaki limestone. Specimens from the lower horizons (Iw I and I $w$ II) are similar to the topotypes of Yabeina shiraiwensis from the Akiyoshi area. As suggested by NoGAMI (1961, p. 217), the specimens from the higher horizon (Iw III) have a larger shell and proloculus and resemble Lepidolina multiseptata of the typelocality in Cambodia.

m) Jenka Pass and Kampong Awah, Central Pahang, Malaya. The Middle Permian limestone at Jenka Pass and Kampong Awah, Central Pahang provides us well preserved specimens of Lepidolina (sample $J p$ and $K a$ ). Kampong Awah is the type locality of Yabeina asiatica IsHII, 1966.

n) North Auckland Peninsula, North Island, New Zealand. HoRNBrook (1951) reported the occurrence of Lepidolina multiseptata from the North Auckland Peninsula, North Island of New Zealand. The specimens from this locality are also studied in this paper (sample $N z$ ). This represents the southern limit of the distribution of this species.

Lepidolina multiseptata ranges from the middle Middle Permian to the lower Upper Permian. The stratigraphic correlation of the fossiliferous beds of the Lepidolina multiseptata lineage is presented in Fig. 2. This correlation chart is based on the data explained above (a-n) and those of previous authors (KANMERA, 1954, 1963; ToRIYAMa, 1967; GobBetT, 1967; NAKAZAWA and NEWELL, 1968; IshII and Shimizu, 1968; Ruzhentsev and SarycheVA, 1968; OzaWA, 1970; KanMera and NAKAZAWA, 1973; and NAKAZAWA et al. 1975)

For the division of the Permian sequence of East Asia, I closely agrees with the difinition expressed by GoBBETT (1967, p. 84-86) in his study on the paleozogeography of the Verbeekinidae. For this problem, the readers may refer to GoBBETT (1967) and KANMERA and NAKAZAWA (1974).

\section{Note on Paleoecology}

The ecology of Lepidolina multiseptata is inferable from the shell morphology, analysis of fossil assemblage, nature of sediments and also from that of the recent species which distinctly converge with it.

The benthonic foraminifera including Lepidolina multiseptata and several other species took important part in forming limestone in the Middle to Upper Permian of the western part of the circum-Pacific region, as Nummulites and Discocyclina did for the Paleocene limestone of the Mediterranean region. As far as is known, the occurrence of Lepidolina multiseptata is almost restricted to the biomicritic limestone rich in remains of calcareous algae and foraminifers and matrix of very fine, lime-silt to -elay. This may denote the deposition under a relatively warm and calm shallow sea environment. Crinoids, bryozoans and waagenophyllid corals are also common in the limestone. It has never been reported from the true reef nor from lagoonal deposits.

In the recent sea fusiform-shelled foraminifers with numerous chamberlets are restricted to shelf environments under a tropical or subtropical climate. The ecology of Lepidolina multiseptata may be well inferable from that of Alveolinella quoyi (d'ORBIGENY) in the recent tropical region. BANDY (1964, p. 79-80) who discussed the correlation of foraminifer structure with environment has paid spe- 
cial attention to Alveolinella and noted that "a modern isomorph of the fusulinid foraminifera of late Paleozoic is the genus Alveolinella, a spindle-shaped genus that abounds in the region of Suru Sea. It is stenohaline, restricted to tropical waters, and generally associated with the larger discoidal forms which have chamberlets." In the Great Barrier Reef, Alveolinella quoyi is restricted to the off-reef shelf (MAXWELL, 1968, p. 174). It is undoubtedly considered that Lepidolina multiseptata was a bottom-dweller on the shallow sea carbonate sedimentary shelf where the warm and calm waters predominated. The species occurs in association with many verbeekinoid, schwagarinid and endothyrid foraminifers, and constitutes a distinct foraminiferal fauna of the Middle to Upper Permian age (OzAWA, 1970, p. 28). It is the dominant species in the foraminiferal assemblage, and in most cases exceeds 60 per cent in the number of individuals. The species diversity of the foraminiferal assemblage is low. The diversity indices range from 2 to 4 . (FISHERWILliams' index; FisheR, CoRbetT and WILLIAMS, 1943)

As GoBBETT (1967, p. 84) presumed, in the young stage the verbeekinoids including Lepidolina probably had an epiplanktonic or planktonic mode of life as in many recent benthonic foraminifers. The passive dispersal of the planktonic phase in the life cycle through sea currents is probably one of the reasons why Lepidolina multiseptata is geographically widespread.

\section{Material}

To clarify the evolutionary history of Lepidolina multiseptata, thirty-four samples which are explained below are used. They cover well the extent of geographic and stratigraphic distribution of the species and are in an excellent state of preservation. I carefully collected the samples from limestone at intervals less than one foot thick at each of the localities, so that a sample may represent populations of as short chronologic unit as possible. These samples may present successions of interbreeding population that inhabited the area where shallow carbonate sediments have been accumulating for thousands to tens of thousands of years. Details regarding the distribution and correlation of the samples have been presented in the preceding chapter.

The samples were primarily collected by me and are preserved at the Department of Geology, Kyushu University. I furthermore used several samples from Cambodia through the courtesy of Dr. IsHII, Department of Geoscience, Osaka City University, Dr. NoGami's collection, Department of Geology and Mineralogy, Kyoto University, Drs. TORIYAMA and KANMERA's collection, Department of Geology, Kyushu University, and Dr. HoRNIBROoK's collection, Geological Survey of New Zealand.

\section{Samples from the middle Middle Permian}

Sample Ka-Kampong Awah Quarry near Kampong Awah on Temerloh Maran Road in Pahang, Malaya; gray calcareous algae-foraminifera biomicrite; 22 individuals; associated foraminifers, Neoschwagerina cheni SHENG, Sumatrina annae "longissima" DEPRAT, Verbeekina verbeeki (GEINITZ), Chusenella sp., Kahlerina sp., Cribrogenerina sp. and Hemigordius sp.; coll. by ISHII and OzAWA.

Sample Jp.-Dark gray limestone at Jenka Pass on Temerloh-Maran Road in Pahang, Malaya; 41 individuals; associated foraminifers, the same species listed above; coll. by OzAWA. 
Sample $C B$-Limestone bed at the uppermost horizon of the B Member of the Permian limestone of West Cambodia in Phnom Takream, west of Battambang; the lowest stratigraphic level of the Lepidolina multiseptata horizons in the limestone; 70 individuals; associated foraminifers, Neoschwagerina sp. aff. $N$. margaritae DEPRAT, Sumatrina annae VoLZ, Verbeekina verbeeki (GEINITZ) and Chusenella sp.; coll. by IsHII.

Sample $S g I$-Limestone lens intercalated in a tuffaceous shale exposed on the cliff, immediately east of the Shigeyasu station, Omine, Mine-shi, Yamaguchi Prefecture, Japan (Lat. $34^{\circ} 11.5^{\prime} \mathrm{N}$; Long. $131^{\circ} 12.4^{\prime} \mathrm{E}$ ) ; about $3 \mathrm{~m}$ above the bed containing Colania douvillei (OzAWA) and Neoschwagerina margaritae DEPRAT; 45 individuals; associated foraminifers, Chusenella sp., Dunbarula sp., Ozawainella sp., Kahlerina sp., Pachyphloia sp. Hemigordius sp.; coll. by OzAWA.

\section{Samples from the upper Middle Permian}

Sample Sg II-Calcareous algae rich limestone on the cliff, east of the Shigeyasu station, and stratigraphically about $8 \mathrm{~m}$ above the $S g I$ in the same stratigraphic section ; 61 individuals ; associated foraminifers, Sumatrina annae "longissima" DEPRAT, Verbeekina sp. and Kahlerina sp.; coll. by OzAWA.

Sample Sg III-Gray biomicritic limestone on the road side cut, east of the Shigeyasu station, in the same stratigraphic section as the samples $S g I$ and $S g I I$ and stratigraphically about $5 \mathrm{~m}$ above the $S g I I$; 185 individuals (182 megalospheric and 3 microspheric specimens) ; associated foraminifers, Sumatrina annae “longissima" DePRAT, Chusenella sp., Dunbarula sp., Nankinella sp., Kahlerina sp. and Pachyphloia sp.; coll. by Ozawa.

Sample Sh-Gray limestone in the southeast of Shiraiwa, Mine-shi, Yamaguchi Pref. (Lat. $34^{\circ} 11.5^{\prime} \mathrm{N}$, Long. $131^{\circ} 10.8^{\prime} \mathrm{E}$ ) ; 110 individuals ; associated foraminifers, Sumatrina annae "longissima" DFPRAT, Chusenella sp., Dunbarula sp., Rauserella sp., Kahlerina sp., Pachyphloia sp., Tetrataxis sp. and Hemigordius sp.; coll. by the late Dr. Y. OzAWA, IsHII and NoGAMI.

Sample Yo I-Gray limestone exposed along the road which runs from the west of Yobara, via Serita to Irimi, Shuho-cho, Yamaguchi Pref. (Torryama, 1958, loc. 753 ; about $350 \mathrm{~m} \mathrm{SW}$ of Yobara; Lat. $34^{\circ} 13.6^{\prime} \mathrm{N}$, Long. $131^{\circ} 15.0^{\prime} \mathrm{E}$ ) ; the same stratigraphic horizon as Sample $S g I I I$ in the Akiyoshi limestone group; 42 individuals; associated foraminifers, Chusenella sp., Dunbarula sp., Kahlerina sp. and Pachyphloia sp.; coll. by OzawA.

Sample Yo II-Gray, foraminifera rich limestone, stratigraphically about $8 \mathrm{~m}$ above Sample $Y o I$ in the limestone sequence of the same area as $Y o I$; 59 individuals; associated foraminifers, Sumatrina annae "longissima" DEPRAT, Chusenella sp. and Kahlerina sp.; coll. by OzAWA.

Sample Yo III-Black biomicritic limestone exposed along the road which runs through the west of Yobara, Beppu, Shuho-cho; the same stratigraphic section as Yo $I$ and $Y_{0} I I$, and stratigraphically about $10 \mathrm{~m}$ above Yo II; 69 individuals; associated foraminifers, Sumatrina annae "longissima" DEPRAT; coll. by OzAWA.

Sample Ha I-Gray limestone exposed at about $80 \mathrm{~m}$ SW of the Hinode Quarry, about $900 \mathrm{~m}$ south of Hagiwara, Ofuku, Mine-shi, Yamaguchi Pref. (Lat. $34^{\circ} 14.3^{\prime} \mathrm{N}$, Long. $131^{\circ} 13.1^{\prime} \mathrm{E}$ ) ; approximately the same stratigraphic horizon as Sample Yo II in the Akiyoshi limestone group; 78 individuals (4 microspheric specimens included) ; associated foraminifers, Verbeekina sp., Chusenella sp., Rauserella sp., Pachyphloia sp. and Cribrogenerina sp., coll. by OzAWA. 
Sample $H a I I$-Silicified black biomicritic limestone exposed near the $H a I$ locality, stratigraphically $7 \mathrm{~m}$ above $H a I$ in the same stratigraphic section; 46 individuals; coll. by OzaWA.

Sample Ir-Gray to dark gray limestone exposed at Irimi along the road between Yobara and Irimi, Shuho-cho, Mine-gun, Yamaguchi Pref. (Lat. $34^{\circ} 13.0^{\prime} \mathrm{N}$, Long. $\left.131^{\circ} 14.3^{\prime} \mathrm{E}\right)$; 70 individuals ; coll. by IsHIBASHI.

Sample $M d$-Conglomeratic limestone intercalated in black shale of the Maedani formation, exposed at Maedani, Tojo-cho, Hiba-gun, Hiroshima Prefecture (Lat. $34^{\circ} 53.5^{\prime} \mathrm{N}$, Long. $133^{\circ} 12.6^{\prime} \mathrm{E}$ ) ; 29 individuals; associated foraminifers, Sumatrina annae "longissima" DEPRAT and Chusenella sp.; coll. by OzAWA.

Sample TeL-Limestone exposure (SADA, 1959, Loc. Yu-24), about $700 \mathrm{~m}$ southwest of Iwamoto, Niimi-shi, Okayama Pref. (Lat. $34^{\circ} 57.0^{\prime} \mathrm{N}$, Long. $130^{\circ}$ 35.1' E) ; stratigraphic horizon, lower part (lower part of the lower subzone of Lepidolina multiseptata shiraiwensis zone by NoGAMI, 1961) of the Terauchi formation in the Atetsu limestone plateau; 39 individuals; associated foraminifers, Sumatrina annae "longissima" DEPRAT, Chusenella sp., Kahlerina sp., etc.; coll. by OzAWA.

Sample Tem-Gray limestone exposed at the point about 550 m north of Mitsuto (NogAMI, 1962, loc. 6), Niimi-shi, Okayama Pref. (Lat. $34^{\circ} 57.2^{\prime} \mathrm{N}$, Long. $130^{\circ} 36.0^{\prime}$ E) ; upper part of the lower subzone of Lepidolina multiseptata shiraiwensis zone by NoGAMI, $1961 ; 22$ individuals (18 megalospheric and 4 microspheric specimens) ; associated foraminifers, Sumatrina annae "longissima" DEPRAT and Chusenella otai NogAMI; coll. by NoGAMI.

Sample TeU-Conglomeratic black limestone exposed at the road side along the road between Yukawa and Iwamoto in the Atetsu plateau (SADA, 1959, loc. $\mathrm{Yu}-53$, Lat. $34^{\circ} 58.5^{\prime} \mathrm{N}$, Long. $130^{\circ} 35.0^{\prime} \mathrm{E}$ ) ; about $55 \mathrm{~m}$ stratigraphically above $\mathrm{TeL}$ in the same stratigraphic section, the highest fossil horizon of Lepidolina in the Terauchi formation (upper part of the upper subzone of Lepidolina multiseptata shiraiwensis zone by NoGAMI, 1961); 33 individuals; coll. by OzaWA.

Sample Om-Omi limestone on the eastern bank of Omi-gawa river, east of Shimizukura, Omi-cho, Nishikubiki-gun, Niigata Pref., central Japan (Lat. $36^{\circ}$ $59.0^{\prime} \mathrm{N}$, Long. $137^{\circ} 46.5^{\prime} \mathrm{E}$ ) ; 300 individuals (8 microspheric specimens included) ; associated foraminifers, Sumatrina annae "longissima" DEPRAT, Verbeekina sp. cf. V. verbeeki (GEINITZ), Chusenella sp., Nankinella sp., Dunbarula sp., Kahlerina sp., Pachyphloia sp., Tetrataxis sp. and Hemigordius sp.; coll. by OzAWA.

Sample Iw I-Limestone exposed on the sea side of Iwaizaki, Hashigami-mura, Motoyoshi-gun, Miyagi Pref., Northeast Japan (Lat. $38^{\circ} 49.5^{\prime} \mathrm{N}$, Long. $141^{\circ} 36.2^{\prime}$ E) ; the lowest part of the Lepidolina shiraiwensis zonule (MoRIKAWA et al., 1958, point 25, e-bed) of the Iwaizaki limestone; 30 individuals ; associated foraminifers, Verbeekina sp., Chusenella sp., Kahlerina sp. and Pachyphloia sp.; coll. by OzAwA.

Sample Iw II-Dark gray limestone bed (MoRIKAWA et al., 1958, point 7 in the $\mathrm{g}$-bed) in the Iwaizaki limestone; stratigraphically about $45 \mathrm{~m}$ above the $I w I$ horizon and $4 \mathrm{~m}$ below the $I w I I I$ in the same limestone sequence; 57 individuals; associated foraminifers, Dunbarula sp., Kahlerina sp., etc.; coll. by OzAwA.

Sample I $w$ III-Black limestone bed exposed on the sea cliff of Iwaizaki (MORIKAWA et al., 1958, loc. 5 in the g-bed) ; 85 individuals; associated foraminifers, Chusenella sp., Nankinella sp., Dunbarula sp., and several other microforaminifers ; coll. by Ozawa.

Sample $\mathrm{PbC}$-Reddish brown limestone in the west of Phnom Lang K. Tom in 
Sisophon, Cambodia; middle part of the C Member of the Sisophon limestone; 37 individuals; associated foraminifers, Sumatrina annae "longissima" DEPRAT, Chusenella cambodiensis (GUBLER), Nankinella sp. and Kahlerina sp.; coll. by IsHII.

Samples from the lower part of the lower Upper Permian

Sample $\mathrm{Ym}$-Calcareous algae rich limestone at Yasumoto, Tojo-cho, Hiba-gun, Hiroshima Pref. (loc. SADA and YokoYama, 1966, text-fig. 1, Lat. $34^{\circ} 50.5^{\prime} \mathrm{N}$, Long. $133^{\circ} 14.1^{\prime} \mathrm{E}$ ) ; 121 individuals (3 microspheric specimens included); associated foraminifers, Chusenella sp., Codonofusiella sp., Nankinella sp., Kahlerina sp. and Cribrogenerina sp.; coll. by OzAWA.

Sample $\mathrm{Yb}$-Conglomeratic limestone exposed on the road side between Yasuba and Wakamiya-onsen, in Yasuba, Tosayamada-shi, Kochi Pref., Shikoku, Japan (Lat. $33^{\circ} 39.5^{\prime} \mathrm{N}$, Long. $133^{\circ} 41.0^{\prime} \mathrm{E}$ ) ; 57 individuals; associated foraminifers, Chusenella sp., Codonofusiella sp., Nankinella sp. and Kahlerina sp.; coll. by ToRIYAMA, IsHII and NoGAMI.

Sample $F u$-Black limestone exposed on the river side of the Tama-gawa river in Futamatao, Ome-shi, Tokyo (Lat. $35^{\circ} 49.5^{\prime} \mathrm{N}$, Long. $139^{\circ} 13.1^{\prime} \mathrm{E}$ ) ; 226 individuals (221 megalospheric and 5 microspheric specimens) ; associated foraminifers, Metadoliolina multivoluta (SHENG), Chusenella cambodiensis (GUBLER), Chusenella sp., Codonofusiella cuniculata KANMERA, Dunbarula sp., Nankinella inflata (CoLANI) and Kahlerina sp.; coll. by Ozawa.

Sample Nz-Tuffaceous limestone exposed on Kairaukaru Bay, near Whaingaroa, North Auckland Peninsula, North Island, New Zealand; 23 individuals (preservation not excellent) ; coll. by HoRNBROoK.

Sample PbDl-Limestone outcrop about $500 \mathrm{~m}$ SE of Phnom Bak, Sisophon, Cambodia; basal part of the D Member of the Sisophon limestone, stratigraphically about $30 \mathrm{~m}$ above Sample $P b C ; 48$ individuals (6 microspheric specimens included) ; coll. by ISHII.

Sample PsB-Phnom Sampou, $13 \mathrm{~km}$ SW of Battambang, Cambodia; probably lower part of the D Member of the Permian limestone of West Cambodia; 41 individuals; associated foraminifers, Chusenella globularis (GUBLER); coll. by VIEN RAY.

Sample Pt-Limestone at Phnom Takream, Battambang, Cambodia ; lower part of the D Member of the Permian limestone of West Cambodia by IsHII et al.; 28 individuals; coll. by IsHII.

\section{Samples from the upper part of the lower Upper Permian}

Sample PsA-Phnom Sampou, $13 \mathrm{~km}$ SW of Battambang, Cambodia; upper part of the D Member of the Permian limestone of West Cambodia; 36 individuals; coll. by IsHII and NoGAMI.

Sample $\mathrm{Pl}-\mathrm{Phnom}$ Lang K. Tom, Sisophon, Cambodia; the uppermost part of the D Member of the Sisophon limestone; 17 individuals; coll. by IsHII and NoGAMI.

Sample $P b D u$-Phnom Bak, Sisophon, Cambodia; upper part of the D Member of the Sisophon limestone, stratigraphically about $50 \mathrm{~m}$ above the $P b D l$ horizon; 159 individuals; associated foraminifers, Verbeekina sp., Chusenella cambodiensis (GUBleR), Codonofusiella sp., Dunbarula sp., Nankinella inflata (ColANI) and Kahlerina sp.; coll. by IsHII and NoGAMI.

Sample $\mathrm{Sa}$-Lenticular limestone exposed on the river floor of the Naka-gawa valley, Sakashu, Kizawa-mura, Tokushima Pref., Shikoku, Japan (Lat. $33^{\circ} 49.2^{\prime}$ N, 
Long. $134^{\circ} 18.2^{\prime} \mathrm{E}$ ) ; 115 individuals (2 microspheric specimens included); associated foraminifers, Chusenella sp., Codonfusiella cuniculata KANMERA, Dunbarula sp., Nankinella sp., Cribrogenerina sp. and Pachyphloia sp.; coll. by Ozawa.

Sample $K m$-Black conglomeratic limestone exposed at the point (KANMERA, 1953, loc. 499), about $1.5 \mathrm{~km} \mathrm{NE}$ of Kasamatsu, Yatsushiro-gun, Kumamoto Pref., Kyushu, Japan (Lat. $32^{\circ} 31.7^{\prime}$ N, Long. $130^{\circ} 46.1^{\prime} \mathrm{E}$ ) ; 62 individuals ; associated foraminifers, Lepidolina kumaensis KANMERA, Metadoliolina gravitesta (KANMERA), Chusenella pseudocrassa (KANMERA), Codonofusiella cuniculata KANMERA, Dunbarula sp., Rauserella sp., Reichelina sp., Parareichelina subangusta SosNINA, Sichotenella maichensis Sosnina, Nankinella sp., Staffella sp., Kahlerina sp., Colaniella sp., Wanganella sp., Pachyphloia sp., Nodosarina grandecamerata Sosnina, Nodosaria sp., Geinitzina sp., Tetrataxis sp., Monotaxinoides sp., Agathammina sp. and Cribrogenerina sp.; coll. by KANMERA and OzAwA.

\section{Methods}

Many of structural features of Lepidolina shell are internal, although some are external. To study the internal shell structures under the microscope, the material was prepared by making well oriented thin sections from specimens embedded in limestone as well as free ones (Fig. 3, C, D). The extent of variation has been analysed by means of current biometric techniques.

\section{A. Morphometry}

For the general morphologic characters of the fusulinid foraminifers, the readers may refer to DUNBAR and SKINNER (1937) and THOMPSON (1964). The basic morphology in Lepidolina shell is presented in Fig. 3.

Prolocular diameter-Most individuals have a spherical or an ellipsoidal proloculus with one to three prolocular apertures (Pl. 26, Fig. 10). The longest outside diameter of the proloculus is taken as the prolocular diameter within an accuracy of 8 microns.

Radius vector-This is measured perpendicularly to the axis of coiling from the center of the proloculus to the outer surface of the tectum of the spirotheca of each consecutive volution. The measurements are given within an accuracy of 8 microns.

Half length-The half length is measured at every volution on axial-sectioned specimens from the center of the proloculus to the outer surface of the tectum at the polar end.

Shell form (form ratio) - This is defined as the proportion of the half length and the radius vector for each consecutive volution. The convexity of lateral slopes is also considered in relation to the form ratio.

Thickness of spirotheca-This (=protheca) is determined as the sum of two layers, the tectum and keriotheca, for each consecutive volution. The thickness is recorded in the equatorial area.

Number of volution-It is determined as the number of chamber roof in specimens cut through the proloculus. The proloculus is not counted.

Number of septa-It is counted for each consecutive volution.

Number of axial septula-The axial septula increase in number with growth. The maximum number of them between two adjacent septa is counted for each consecutive volution. 

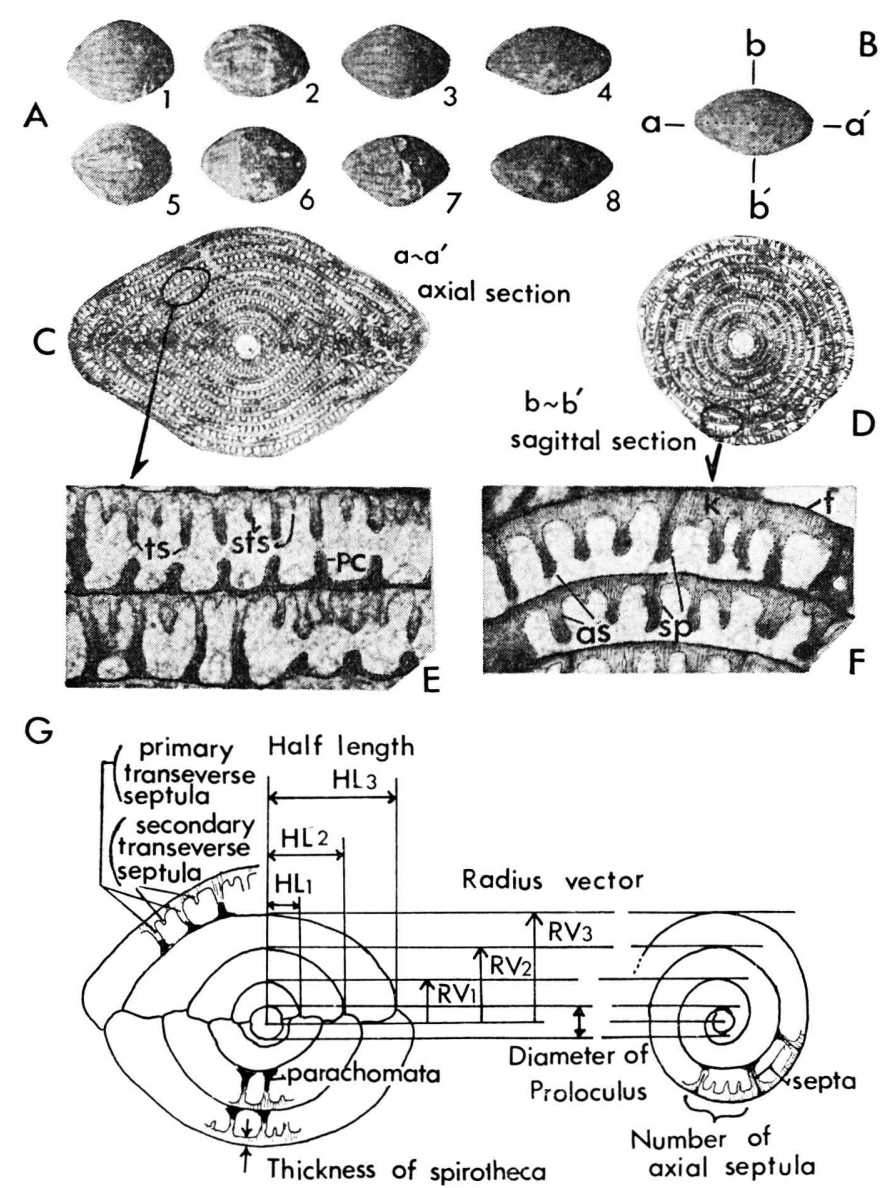

Fig. 3. Basic morphology and measurements of Lepidolina multiseptata. A, external views; $1-4$, specimens in sample $P b C, 5-8$, specimens in sample $H a I$. B, orientation of the sections of shell. C, axial section. D, sagittal section. E, enlarged figure of a part of an axial section showing internal shell structures; ts, primary transverse septula, sts, secondary transverse septula, pc, parachomata. F, enlarged figure of a part of a sagittal section showing internal shell structures; sp, septa, as, axial septula, $t$, tectum, $k$, keriotheca. G, scheme of measurements for Lepidolina multiseptata.

Secondary transverse septula-The first appearance and the number of secondary transverse septula in the course of shell growth have been examined.

Shape and features of primary transverse septula, septa and parachomata are also examined.

\section{B. Statistical treatment}

The statistics presented in the following discussion of variation are the arithmetic mean, standard error of the mean, 95 per cent confidence intervals of the 
mean, standard deviation, coefficient of variation and coefficient of difference. The coefficient of variation is used to express the intrapopulational variation in the measured characters (PEARSON's coefficient of variation).

Measurement data tables-The statistical data for mensural characters are presented on Table 1-3.

Explanation of figures-The observed range of variation is shown by the length of horizontal line; two standard deviations and mean are indicated by a white rectangles and cross line, respectively; a black rectangle represents the 95 per cent confidence limits for the mean.

Significance of difference-When the data of a measurement or an index is comparable with a normal distribution and the observed data could be tested for their goodness of fit to a normal distribution using test, the following procedures are undertaken as the comparison of samples. Samples from the same population probably show similar variance of a character. If the difference between two sample variance of a character is significant or highly significant, one may suggest the two samples came from different populations. A statistical difference between the two sample variances can be based on the value of SNEDECOR's $F$ which is given as the ratio of two sample variances. The 5 per cent level of probability is here chosen as the criterion for the rejection of the null hypothesis in two sided test. As to the samples between which the difference of variances is not significant, GossET's $t$-test has been used as the measure of difference between the means of two samples. The 1 per cent or 5 per cent level of probability is chosen for the significance.

The following two methods of expressing the difference between populations are also considered in the present study. The means of the samples are statistically significantly different if the bar of black rectangles in the figures representing $\mathbf{9 5}$ per cent confidence intervals of one mean does not overlaps the bar representing that of the other mean.

The coefficient of difference (MAYR, LINSLEY and USINGER, 1953, p. 146; MAYR, 1969 , p. 189) has been used to express interpopulational variation in contemporaneous samples. With a coefficient of difference of $1.28,90$ per cent of one population can be distinguished from 90 per cent of the other. This index is also applied for the comparison of allochronic samples of Lepidolina multiseptata (DEPRAT, 1912).

The following conventional abbreviations are used in this paper.

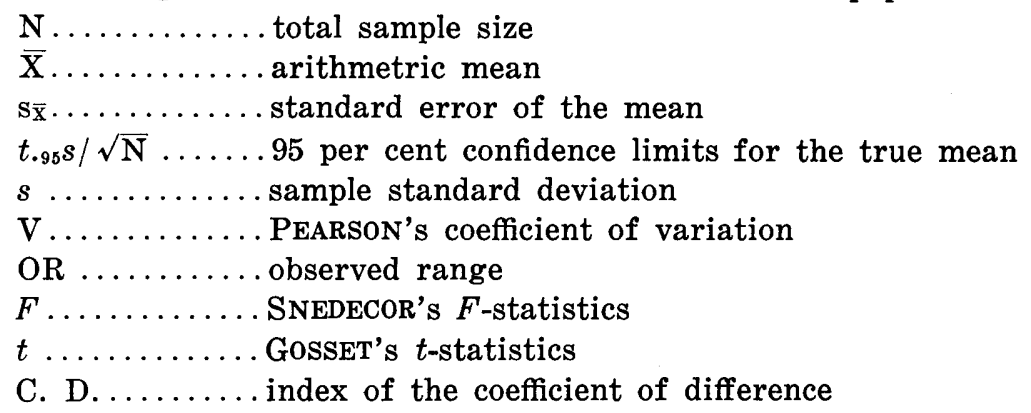

\section{Recognition of shell maturity and comparison of samples}

Most organisms remarkably change their shape and size through ontogenetic development. In the fusulinid foraminifers including Lepidolina multiseptata, shell form and other morphologic characters change more or less rapidly with 
growth. Therefore, the mature shells are generally very different in shape and other characters from the immature ones. The average form ratio in the megalospheric specimens, taking Sample $F u$ as an example, changes from about a unit value in the first volution to more than 2 in the fifteenth volution (Fig. 10). In the microspheric shells, it changes remarkably from about a unit value to more than 4 in the mature stage. Similar phenomena are also recognized in other morphologic characters, radius vector (Fig. 9), half length, number of axial septula, thickness of spirotheca, etc. These facts indicate that the comparison of samples must be done with careful consideration of the growth stage. As is clear in Figure 10, the form ratio rapidly increases from the first volution to the seventh or eighth volution. Passing through the eighth volution, it increases slowly until the last volution. The shift of slope from a steep grade to a gentle grade in the figure corresponds to the "critical point" on the allometric line which shows a relation between the radius vector and the half length (Fig. 11). The relation between the two characters is represented as two straight lines on double logarithmic graphs and may be regarded as diphasic allometry. Each point on the graphs indicates the mean values of the radius vector and half length in each consecutive volution. The change of a value occurs near the seventh volution in the megalospheric form. In the microspheric shells the change of a value also occurs near the sixth or seventh volution. More or less abrupt change of growth gradient takes place in the sixth to eighth volution in all the samples studied (Fig. 11). It coincides with the stage of better development of secondary septula in the course of shell growth. Judging from these facts, it may be concluded that the individuals of Lepidolina multiseptata probably attain the maturity near the "critical point". Consequently comparison of samples has been principally done at the tenth or later volution in the mature stage.

\section{Variation of Morphologic Characters and Their Chronologic Change}

\section{A. Prolocular diameter}

Frequency distribution histograms in the prolocular diameter are shown in Fig. 4. As is very clear in the figure and Table 1, the variability in the diameter of proloculus within a single sample is quite large. The dimorphism in the diameter is marked in this foraminiferal species. In the histogram there exist two peaks which are completely independent of each other. The small peak lying at 24 to 88 microns represents the proloculi of the microspheric form. The microspheric form in a sample is easily distinguished from the megalospheric one in the prolocular diameter. The observed range of measurements for megalospheric specimens of Sample $F u$, for instance, varies from 262 to 728 microns in 224 individuals. In most of the sufficiently large samples the maximum value is more than two and a half times the minimum in the same sample. The coefficient of variation for megalospheric specimens is very large. It varies from $\mathbf{1 5 . 3 3}$ to $\mathbf{3 0 . 3 3}$, averaging 23.00 for 34 samples. The observed range of the prolocular diameter increases as the stratigraphic horizon becomes higher, as is shown by greater standard deviation.

The geographic variation in the diameter of proloculus is slight among the samples which are considered to have been drawn from nearly contemporaneous beds (Fig. 5). Among the samples from the lower part of the upper Middle Per- 


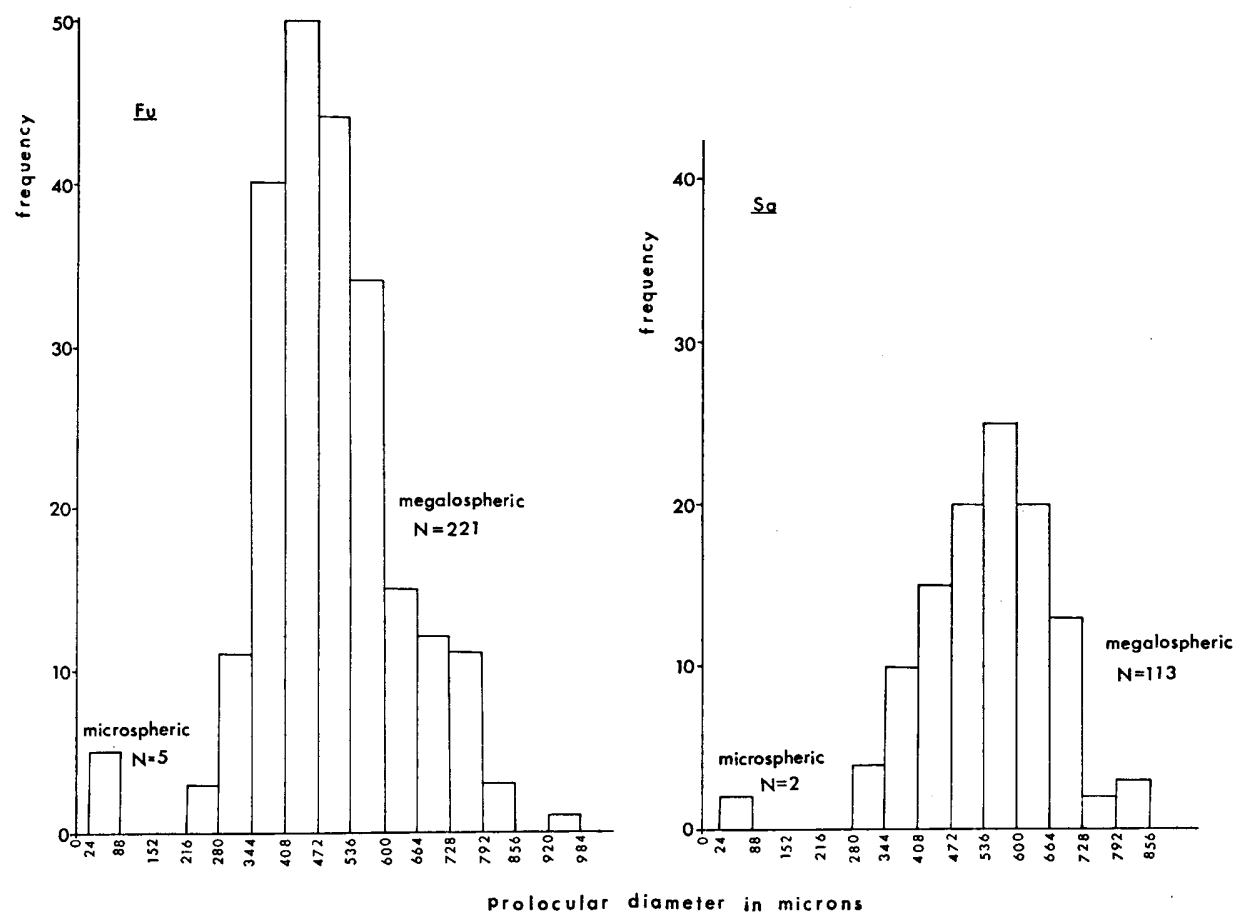

Fig. 4. Frequency distribution histograms of the prolocular diameter showing dimorphism and marked individual variation.

mian ( $=\mathrm{Cl}$ horizon), the megalospheric specimens vary in mean prolocular diameter from 300.3 to 330.38 microns (Table 1). This range of variation is small, if we compare it with the 95 per cent confidence intervals of the mean of samples. Samples, Yo II, Sg III, Ha I and Sh, came from nearly the same stratigraphic horizon in the Akiyoshi province in western Chugoku, Japan. The difference among these samples is very slight in the mean and observed range. There is no significant difference in the mean prolocular diameter between the Akiyoshi samples from Southwest Japan and Sample Om from central Japan. These samples of the Cl horizon from Japan are essentially the same as Sample $P b C$ from Southeast Asia in the mean prolocular diameter. The difference between the means in eight samples is always insignificant at the 5 per cent level. The coefficient of difference in this characer between the samples in the $\mathrm{Cl}$ horizon in the Middle Permian ranges from 0 to 0.19 . The pattern of geographic variation of the prolocular diameter in other stratigraphic horizons resembles in general tendency that of the $\mathrm{Cl}$ horizon discussed above. Among the samples from the highest straigraphic horizon ( $\mathrm{Du}$ ), the megalospheric specimens vary in the mean diameter from 515.76 to 554.06 microns. This range is narrower than one third of the standard deviation of a sample of this horizon. Thus, there is no significant difference between the means of the samples. The coefficient of difference between the sampls takes the maximum value of 0.15 .

Summarizing the above, it is concluded that the geographic variation in the prolocular diameter of this foraminifer is very small.

The prolocular diameter, however, markedly changes chronologically (Fig. 5). 
Table 1. Prolocular diameter (in microns) in the whole samples of Lepidolina multiseptata.

\begin{tabular}{|c|c|c|c|c|c|c|}
\hline sample & $\mathrm{N}$ & $\overline{\mathrm{X}}$ & $t_{.95} s / \sqrt{\mathrm{N}}$ & $s$ & $\mathrm{~V}$ & OR. \\
\hline CB & 70 & 209.37 & 9.54 & 39.92 & 19.07 & $128-304$ \\
\hline $\mathrm{Ka}$ & 8 & 220.00 & 50.64 & 62.11 & 28.23 & $144-446$ \\
\hline $\mathrm{Jp}$ & 41 & 247.80 & 17.60 & 55.78 & 22.51 & $160-368$ \\
\hline Sg I & 43 & 224.00 & 20.49 & 66.52 & 29.70 & $96-432$ \\
\hline Iw I & 30 & 282.12 & 20.57 & 55.18 & 19.56 & $192-384$ \\
\hline TeL & 39 & 288.82 & 17.73 & 54.81 & 18.98 & $176-400$ \\
\hline Sg II & 61 & 285.90 & 14.08 & 55.00 & 19.24 & $208-400$ \\
\hline Yo I & 42 & 316.56 & 21.23 & 68.11 & 21.52 & $176-464$ \\
\hline $\mathrm{Om}$ & 292 & 314.19 & 8.18 & 71.28 & 22.69 & $176-640$ \\
\hline $\mathrm{Md}$ & 29 & 323.86 & 41.61 & 109.58 & 33.83 & 160-544 \\
\hline $\mathrm{Ha} \mathrm{I}$ & 74 & 330.38 & 18.70 & 80.43 & 24.35 & 176-560 \\
\hline Yo II & 59 & 320.81 & 20.53 & 78.86 & 24.58 & $192-672$ \\
\hline Sg III & 182 & 300.30 & 11.76 & 80.94 & 26.95 & $128-688$ \\
\hline Sh & 100 & 318.72 & 19.14 & 96.66 & 30.33 & 176-640 \\
\hline $\mathrm{PbC}$ & 37 & 323.46 & 18.37 & 55.31 & 17.10 & $240-448$ \\
\hline Ha II & 46 & 341.22 & 21.30 & 71.88 & 21.06 & $208-528$ \\
\hline Yo III & 69 & 360.80 & 17.14 & 71.20 & 19.74 & $192-560$ \\
\hline Ir & 70 & 369.14 & 19.89 & 83.22 & 22.54 & $208-620$ \\
\hline Iw II & 57 & 377.82 & 27.83 & 105.07 & 27.81 & 192-672 \\
\hline Iw III & 85 & 389.46 & 19.87 & 91.96 & 23.61 & 244-656 \\
\hline $\mathrm{TeM}$ & 18 & 399.11 & 43.08 & 87.02 & 21.81 & $240-560$ \\
\hline $\mathrm{TeU}$ & 33 & 388.36 & 39.71 & 111.81 & 28.79 & 208-672 \\
\hline Ym & 118 & 410.44 & 16.09 & 88.24 & 21.50 & $256-672$ \\
\hline $\mathrm{Nz}$ & 23 & 396.52 & 38.88 & 90.12 & 22.73 & $272-576$ \\
\hline $\mathrm{Yb}$ & 57 & 411.79 & 28.26 & 106.67 & 25.90 & $224-656$ \\
\hline $\mathrm{Pt}$ & 28 & 442.27 & 27.56 & 71.18 & 16.09 & 320-592 \\
\hline $\mathrm{PbDl}$ & 42 & 484.95 & 28.20 & 90.47 & 18.66 & $272-608$ \\
\hline $\mathrm{Fu}$ & 221 & 494.90 & 15.26 & 116.50 & 21.50 & $240-928$ \\
\hline PsB & 41 & 460.88 & 24.87 & 78.80 & 17.10 & $256-592$ \\
\hline PsA & 36 & 540.44 & 27.61 & 82.84 & 15.33 & $400-752$ \\
\hline $\mathrm{Pl}$ & 17 & 515.76 & 64.49 & 125.92 & 24.42 & 336-832 \\
\hline $\mathrm{PbDu}$ & 159 & 552.16 & 22.15 & 142.52 & 27.29 & $240-1024$ \\
\hline $\mathrm{Sa}$ & 113 & 553.20 & 23.64 & 126.91 & 22.94 & $304-848$ \\
\hline $\mathrm{Km}$ & 62 & 554.06 & 34.28 & 134.96 & 24.36 & $192-832$ \\
\hline \multicolumn{7}{|c|}{ Microspheric form } \\
\hline $\mathrm{Om}$ & 7 & 26.94 & 2.88 & 3.23 & 11.97 & $24.6-32.8$ \\
\hline Sg III & 3 & 19.13 & 4.35 & 2.37 & 12.37 & $16.4-20.5$ \\
\hline $\mathrm{TeM}$ & 3 & 39.67 & 11.58 & 6.31 & 15.90 & $32.8-45.2$ \\
\hline Ym & 3 & 27.33 & 8.70 & 4.73 & 17.32 & $24.6-32.8$ \\
\hline $\mathrm{PbDl}$ & 3 & 27.27 & 4.56 & 2.48 & 9.10 & $24.4-28.7$ \\
\hline $\mathrm{Fu}$ & 5 & 34.40 & 9.25 & 6.23 & 18.10 & $25.0-42.0$ \\
\hline
\end{tabular}

The gradual increase in the size distribution of the proloculus is confirmed in the successive sections of the Sisophon limestone in Cambodia and Akiyoshi, Atetsu and Iwaizaki limestones in Japan. The species of the Lepidolina multiseptata lineage occur abundantly at four different horizons of the Sisophon limestone. The mean proloculus diameter of the four samples are 209.37 (Sample $C B, \mathrm{~B}$ member), 323.46 (Sample $\mathrm{PbC}, \mathrm{C}$ member), 484.95 (Sample $\mathrm{PbDl}$, base of $\mathrm{D}$ member) and 


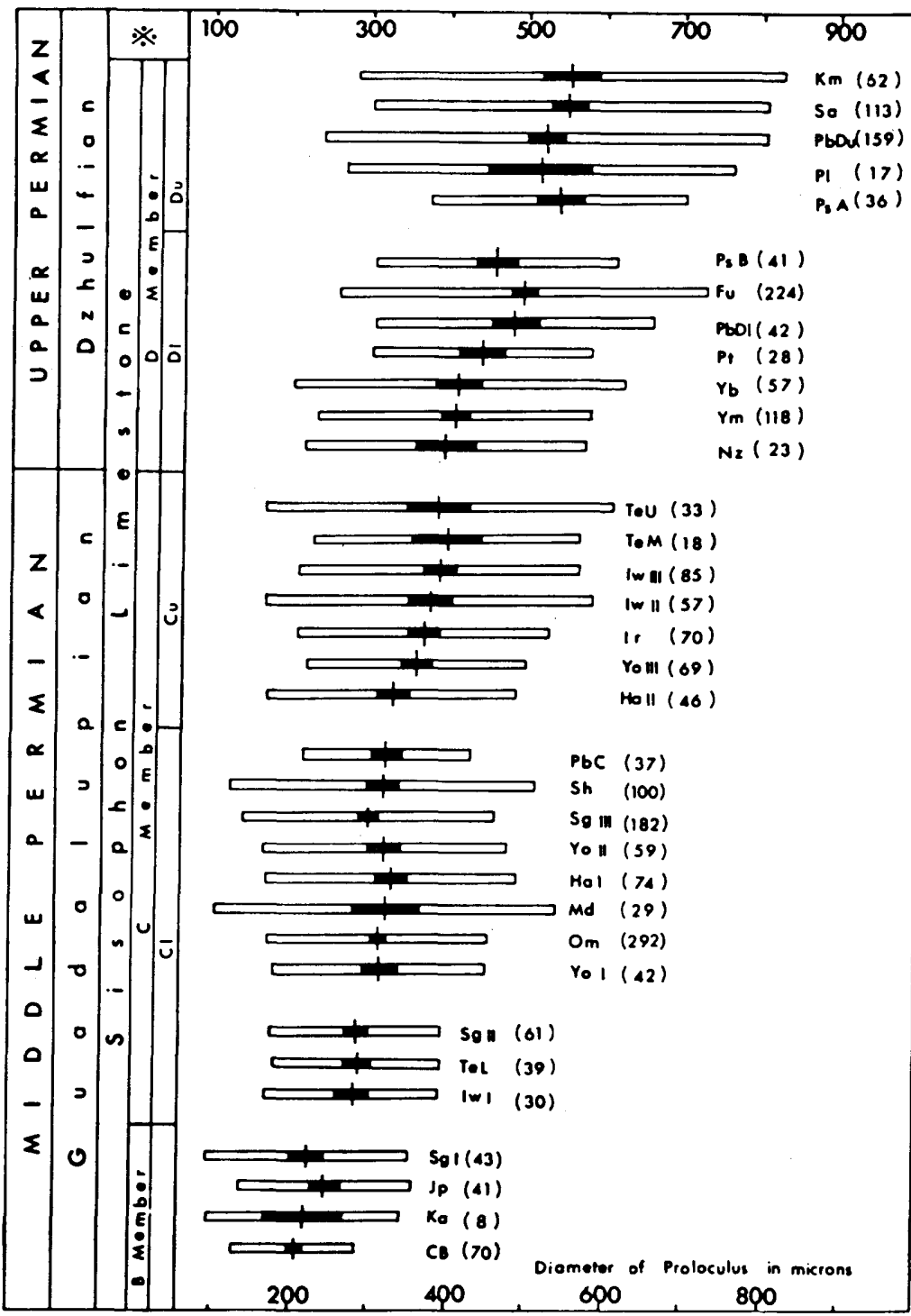

Fig. 5. Variation in the prolocular diameter and its chronologic change in successive populations of Lepidolina multiseptata. The Lepidolina mult?septata succession comprises a series of fossil samples from a continuous population sequence. The horizontal white rectangles includes two standard deviations, the black rectangles represent the 95 per cent confidence limits for the mean, with a vertical line at the sample mean. Horizontal rectangles separated by wide intervals are not of successional occurrence but of almost the same horizon. The number of specimens for each locality is shown in parentheses. (* See explanation in legend for Fig. 2)

522.16 microns (Sample $P b D u$, upper part of $\mathrm{D}$ member) respectively in stratigraphically ascending order. The species of this series also occur abundantly at three different horizons in the Shigeyasu section of the Akiyoshi limestone. The 

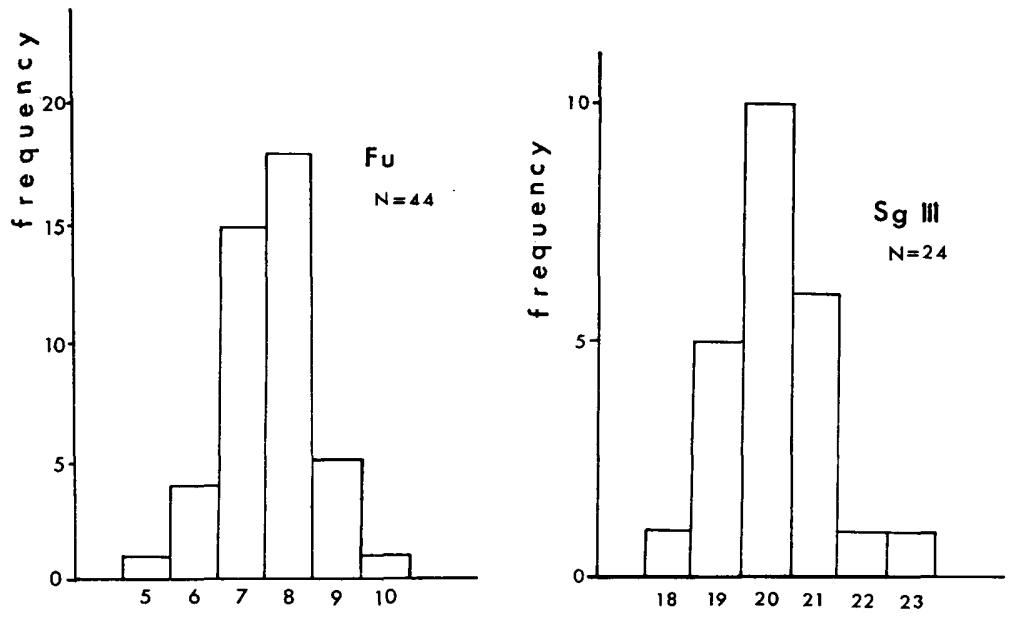

No. of axial septula (10th volution) No. of septa

Fig. 6. Frequency distribution histograms of the number of axial septula (A) and number of septa (B) for the 10th volution.

mean prolocular diameter gradually increase upwards. It is 224.00 (Sample $S g I$ ), 285.90 (Sample $S g I I$ ) and 300.30 microns (Sample $S g I I I$ ) in ascending order. The same tendency is clearly observed in the successive stratigraphic sections of Hagiwara (samples $H a I$ and $H a I I$ ) and Yobara (samples $Y_{O} I, Y_{O} I I$ and $Y_{O} I I I$ ) in the Akiyoshi area, the Terauchi formation in the Atetsu plateau (samples Tel, $T e M$ and $T e U$ ) and the Iwaizaki limestone in Northeast Japan (samples $I w I$, $I w I I$ and $I w I I I)$. It is noteworthy that the increasing size of the prolocular diameter in the Akiyoshi, Atetsu and Iwaizaki limestones coincides well with those in the Sisophon limestone. As is ascertained in the Middle and Upper Permian sequences mentioned above, Lepidolina multiseptata has a clear tendency for the prolocular diameter gradually to increase as the stratigraphic horizon becomes higher. The average prolocular diameter of the samples in six stratigraphi chorizons is $223.50,285.90,314.48,375.36,457.40$ and 537.75 microns, respectively (Fig. 5). The samples from the higher horizons have a greater standard deviation and as the result the difference of variances between the samples of the different horizons is commonly significant at 5 per cent level. The mean prolocular diameter of the samples from the uppermost stratigraphic horizon in the Upper Permian is over twice the mean prolocular diameter of the samples from the lowest horizon in the middle Middle Permian. The coefficient of difference between the samples from most separated horizons is over 2.00 , and is significant.

\section{B. Number of septa}

The number of septa per volution (i.e. septal count) is one of the most stable characters in shell morphology of Lepidolina multiseptata. In this foraminifer, the septa are thin and formed by the downward deflection of a tectum and short extension of a keriotheca on either side of the tectum. The basal part is consolidated by the dark dense materials which are related to parachomata (Fig. 3F). The septa tend to decrease in thickness with time due to the gradual reduction of the keriothecal layer on either side of the tectum of a septum. The number of septa 
Table 2. Maximum number of axial septula in the 10th volution in the selected samples of Lepidolina multiseptata.

\begin{tabular}{lcccccc}
\hline sample & $\mathrm{N}$ & $\overline{\mathrm{X}}$ & $t .95 / \sqrt{\mathrm{N}}$ & $s$ & $\mathrm{~V}$ & OR. \\
\hline CB & 14 & 4.64 & 0.45 & 0.67 & 14.54 & $3-5$ \\
Jp & 18 & 4.89 & 0.38 & 0.76 & 15.51 & $4-6$ \\
$\mathrm{Sg} \mathrm{I}$ & 12 & 4.83 & 0.70 & 1.11 & 23.06 & $3-7$ \\
Iw I & 15 & 4.53 & 0.28 & 0.52 & 11.39 & $4-5$ \\
TeL & 25 & 5.12 & 0.32 & 0.78 & 15.25 & $4-7$ \\
Sg II & 20 & 5.45 & 0.32 & 0.69 & 12.59 & $4-7$ \\
Yo I & 18 & 6.11 & 0.41 & 0.83 & 13.62 & $5-8$ \\
Om & 33 & 6.18 & 0.24 & 0.68 & 11.04 & $5-8$ \\
Md & 20 & 5.75 & 0.37 & 0.79 & 13.68 & $4-7$ \\
Ha I & 28 & 6.07 & 0.36 & 0.94 & 15.48 & $5-8$ \\
Yo II & 28 & 6.39 & 0.41 & 1.07 & 16.67 & $5-9$ \\
Sg III & 35 & 6.29 & 0.32 & 0.93 & 14.73 & $5-8$ \\
Sh & 31 & 5.71 & 0.27 & 0.74 & 12.94 & $4-7$ \\
PbC & 4 & 6.75 & 1.33 & 0.96 & 14.18 & $6-8$ \\
Ha II & 22 & 6.55 & 0.52 & 1.18 & 18.09 & $5-9$ \\
Yo III & 17 & 6.53 & 0.45 & 0.87 & 13.39 & $5-8$ \\
Ir & 17 & 6.53 & 0.45 & 0.87 & 13.39 & $5-8$ \\
Iw II & 22 & 6.18 & 0.48 & 1.10 & 17.75 & $4-8$ \\
Iw III & 30 & 6.73 & 0.29 & 0.78 & 11.66 & $5-8$ \\
TeM & 10 & 6.00 & 0.33 & 0.47 & 7.86 & $5-7$ \\
TeU & 19 & 6.32 & 0.36 & 0.75 & 11.86 & $5-8$ \\
Ym & 35 & 6.80 & 0.31 & 0.90 & 13.25 & $5-8$ \\
Nz & 10 & 6.30 & 0.58 & 0.82 & 13.07 & $5-7$ \\
Yb & 11 & 7.09 & 0.46 & 0.70 & 9.88 & $6-8$ \\
PbDl & 15 & 7.80 & 0.70 & 1.26 & 16.22 & $6-10$ \\
Fu & 44 & 7.57 & 0.30 & 0.97 & 12.87 & $5-10$ \\
PsB & 18 & 7.28 & 0.53 & 1.07 & 14.76 & $5-10$ \\
PbDu & 10 & 8.00 & 0.74 & 1.05 & 13.18 & $6-9$ \\
Sa & 10 & 8.40 & 1.29 & 1.84 & 21.88 & $5-11$ \\
Km & 12 & 8.67 & 0.56 & 0.89 & 10.24 & $8-10$ \\
\hline
\end{tabular}

per volution gradually increases ontogenetically. The range of individual variations of the septal count for a specific volution in the mature stage is slight. For instance, the megalospheric specimens of Sample $S g$ III vary from 18 to 23 in septal count at the tenth volution ( $\overline{\mathrm{X}}=20.17$ having $s=1.89$ and $\mathrm{V}=5.41$ in 24 individuals) (Fig. 6). The septal count of the tenth volution ranges from 18 to 22 in 15 individuals of Sample $F u(\overline{\mathrm{X}}=19.87$ having $s=1.25$ and $\mathrm{V}=6.27)$. The coefficient of variation varies from 2.67 to 9.64 , averaging 6.14 in 21 samples. The interpopulational variation in the septal count is slight as in the case of the prolocular diameter. There is no significant difference in the mean septal count among the samples of the same stratigraphic horizon. No regular pattern is indicated in the variation of this character from the Middle Permian to the Upper Permian samples. The coefficient of difference of Sample $J p$ from the lowest horizon in the Middle Permian and Sample Fu of the Upper Permian is only 0.13. Thus, the septal count is fairly stable among the geographically and chronologically different samples. 


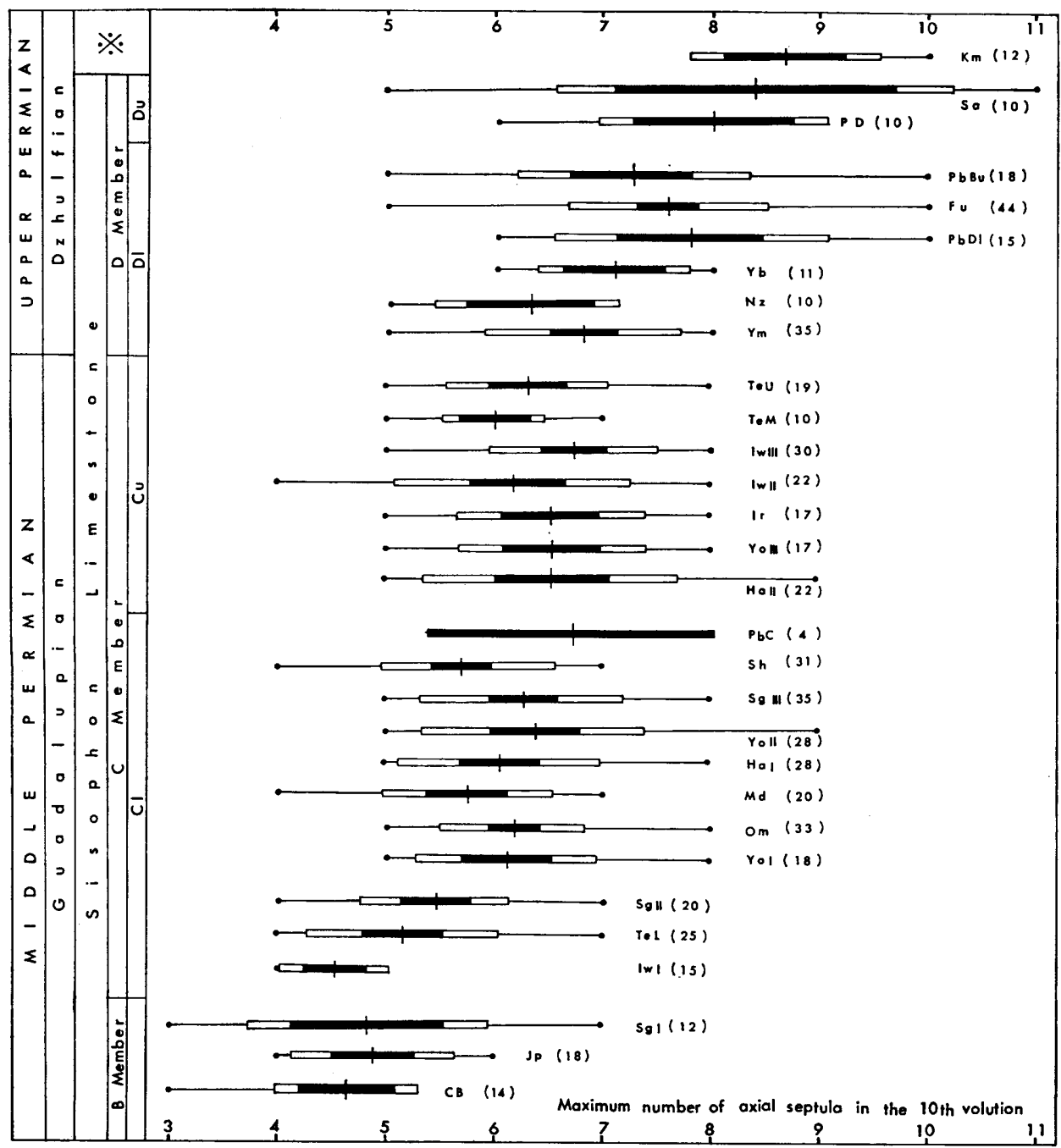

Fig. 7. Variation in the number of axial septula at the 10th volution and its chronologic change in successive populations of Lepidolina multiseptata. The horizontal lines are the observed range for the specimens, the number of which is shown in parentheses; white rectangles represent two standard deviations, and black rectangles the 95 per cent confidence limits for the mean, with a cross line at the sample mean.

\section{Number of axial septula}

Within populations, the axial septula of mature shells are fairly stable in number. The number of axial septula for the tenth volution varies from 4 to 6 in 18 individuals of Sample $J p$ of the middle Middle Permian. It varies from 5 to 8 within samples from the upper Middle Permian which are adequately large in the number of individuals. The samples from the Upper Permian have a little wider range of individual variation than those from the Middle Permian. For instance, the number of axial septula for the tenth volution varies from 5 to 10, averaging 7.58 in 


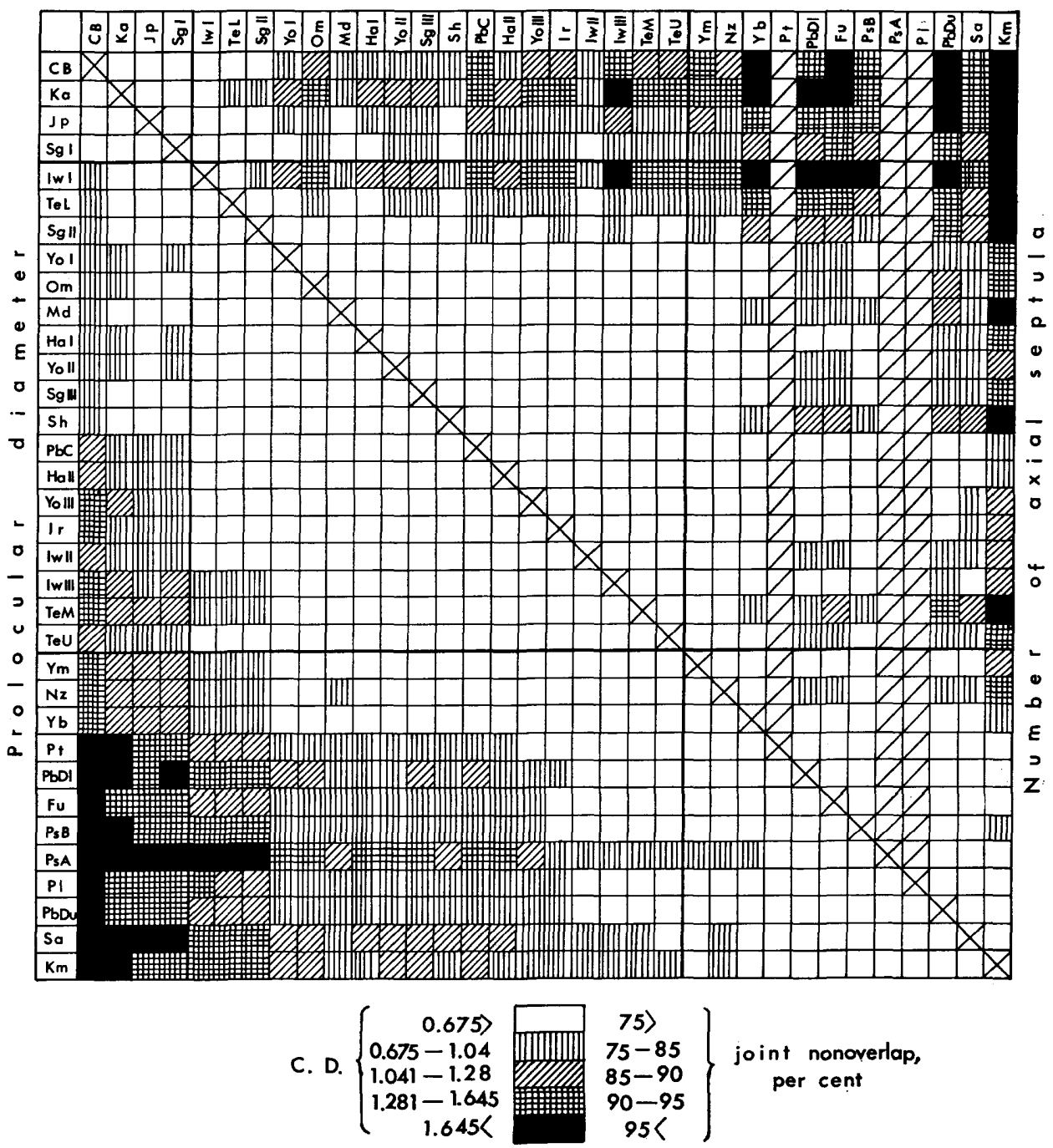

Fig. 8. Matrix of the coefficient of difference (C. D.) of the prolocular diameter and number of axial septula in the whole samples of Lepidolina multiseptata (Data same as Table 1 and Table 2).

44 individuals of Sample $F u$ (Fig. 6). The coefficient of variation of this character ranges from 7.86 to 23.06, averaging 14.13 for 30 samples. As is shown in Figure 7, significant difference in the number of axial septula for the tenth volution is not detected among the geographically separated samples of the same stratigraphic horizon, although slight difference exists in the modal value. In the stratigraphically ascending order, however, there is a definite increase in average number of axial septula of the megalospheric shells (Fig. 7). The means of the samples from the middle Middle Permian ( $=\mathrm{B}$ member) is significantly less than those of the upper Middle Permian ( $=\mathrm{C}$ member), while the means of the Upper Permian samples are significantly greater than those of the upper Middle Permian. The coefficient of difference is over 2.0 between the chronologically most separated 
Table 3. Volution number of the first appearance of the secondary transverse septula in the selected samples of Lepidolina multiseptata.

\begin{tabular}{|c|c|c|c|c|c|c|}
\hline sample & $\mathbf{N}$ & $\overline{\mathbf{X}}$ & $t_{.95} \mathrm{~s} / \sqrt{\mathrm{N}}$ & $s$ & $\mathrm{~V}$ & OR. \\
\hline $\mathrm{CB}$ & 30 & 6.30 & 0.31 & 0.84 & 13.28 & $4-8$ \\
\hline $\mathrm{Ka}$ & 7 & 5.14 & 0.80 & 0.90 & 17.49 & $4-6$ \\
\hline $\mathrm{Jp}$ & 25 & 6.28 & 0.30 & 0.74 & 11.74 & $5-8$ \\
\hline Sg I & 23 & 4.83 & 0.40 & 0.94 & 19.41 & $4-7$ \\
\hline Iw I & 19 & 5.11 & 0.48 & 0.99 & 19.47 & $4-7$ \\
\hline TeL & 18 & 4.17 & 0.30 & 0.62 & 14.84 & $3-5$ \\
\hline $\mathrm{Sg}$ II & 32 & 3.69 & 0.27 & 0.74 & 20.01 & $3-5$ \\
\hline Yo I & 26 & 3.65 & 0.30 & 0.75 & 20.40 & $2-5$ \\
\hline $\mathrm{Om}$ & 38 & 3.58 & 0.25 & 0.76 & 21.18 & $2-5$ \\
\hline Md & 9 & 4.22 & 0.33 & 0.44 & 10.44 & $4-5$ \\
\hline $\mathrm{Ha} \mathrm{I}$ & 24 & 3.46 & 0.33 & 0.78 & 22.53 & $2-5$ \\
\hline Yo II & 22 & 3.32 & 0.37 & 0.84 & 25.28 & $2-5$ \\
\hline Sg III & 43 & 3.74 & 0.19 & 0.62 & 16.58 & $3-5$ \\
\hline Sh & 38 & 3.29 & 0.29 & 0.90 & 27.29 & $2-6$ \\
\hline $\mathrm{PbC}$ & 13 & 3.85 & 0.41 & 0.69 & 17.91 & $3-5$ \\
\hline Ha II & 18 & 3.22 & 0.27 & 0.55 & 17.02 & $2-4$ \\
\hline Yo III & 24 & 2.67 & 0.32 & 0.76 & 28.55 & $1-4$ \\
\hline Ir & 38 & 3.37 & 0.18 & 0.54 & 16.07 & $2-4$ \\
\hline Iw II & 40 & 4.03 & 0.21 & 0.66 & 16.39 & $3-5$ \\
\hline TeM & 6 & 3.67 & 1.03 & 1.03 & 28.17 & $3-5$ \\
\hline $\mathrm{TeU}$ & 18 & 3.44 & 0.39 & 0.78 & 22.76 & $2-5$ \\
\hline $\mathrm{Nz}$ & 12 & 3.67 & 0.49 & 0.78 & 21.23 & $2-5$ \\
\hline Ym & 51 & 3.65 & 0.18 & 0.63 & 17.19 & $2-5$ \\
\hline $\mathrm{Yb}$ & 19 & 3.61 & 0.40 & 0.83 & 22.92 & $3-6$ \\
\hline $\mathrm{PbDl}$ & 26 & 2.73 & 0.27 & 0.67 & 24.42 & $2-4$ \\
\hline PsB & 22 & 3.41 & 0.29 & 0.67 & 19.54 & $2-4$ \\
\hline $\mathrm{PbDu}$ & 41 & 2.27 & 0.20 & 0.63 & 27.92 & $1-4$ \\
\hline $\mathrm{Sa}$ & 45 & 2.54 & 0.17 & 0.56 & 22.10 & $2-4$ \\
\hline $\mathrm{Km}$ & 34 & 2.06 & 0.21 & 0.60 & 29.15 & $1-3$ \\
\hline
\end{tabular}

samples. It is 2.29 between Sample $S g I$ and Sample $\mathrm{Km}$ and ranges of the number of axial septula do not overlap.

\section{Secondary transverse septula}

The secondary transverse septula occur above the foramina throughout the shell of Lepidolina (Fig. 3E). Normally there are two secondary septula between the primary transverse septula in the mature shell. They first appear in inner volution of the immature shell. Within a single sample, the first appearance of the incipient secondary transverse septula is somewhat variable. The first appearance is commonly seen in the fourth or fifth volution in the middle Mddle Permian samples, in the third or fourth volution of the megalospheric shells in the upper Middle Permian ones, and in the first to third volution in the Upper Permian ones (see Table 3). Thus, with respect to this character a tendency of acceleration is seen in the course of evolution of Lepidolina multiseptata as in the case of the Neoschwagerininae. 


\section{E. Radius vector}

The ontogenetic increase in radius vector is illustrated in Figure 9 with the mean and the range of the two standard deviations for each consecutive volution. Since radius vector is directly dependent on prolocular diameter, Lepidolina shells with wide variation in prolocular diameter have consequently a great range of dimensional variability in radius vector at nominally similar volution. The radius vector of the tenth volution for 149 individuals of Sample $F u$ varies from 1040 to 1952 , averaging 1457.6 microns. The maximum value is about twice as much as the minimum at a given volution. The coefficient of variation for the radius vector of the tenth volution ranges from 6.85 to 16.20 and averages 12.37. The radius vector considerably varies between geographically separated samples. Among the eight samples from the $\mathrm{Cl}$ horizon, the mean radius vector in the tenth volution varies from 1147.82 to $\mathbf{1 4 4 6 . 2 0}$ microns for a coefficient of difference of 0.82 . The difference of variance between samples is always insignificant at 5 per cent level. The difference of the mean between samples of this horizon is, with exception of a few cases, almost always significant for $p=0.05$. Similar situation is also recognized among the samples from different stratigraphic horizons. The value of the coefficient of difference of Sample $S a$ from the highest stratigraphic level and Sample $S g I$ from the lowest horizon is only 0.86 in this character. The samples from the higher horizon has a standard deviation similar to those from the lower level. And the difference of variances between the samples is, with exception of several cases, not significant for $\mathrm{p}=0.05$.

\section{F. Half length}

The half length is a variable mensural character. It increases in length through the stratigraphic succession and it also increases in variability concurrently. In younger samples the maximum half length may be as great as twice the minimum half length at a given volution. The coefficient of variation of the half length at the tenth volution for megalospheric specimens averages 13.27 and the extremes are 5.68 and 19.63. The coefficient of difference between samples $S a$ and $C B$ near the top and bottom of the stratigraphic sequence is 2.68 indicating the samples could be distinguished on this character. Geographic variation in half length is also recognizable at a given horizon. Among samples from the $\mathrm{Cl}$ horizon the mean half length at the tenth volution varies from 1853.54 to 2266.40 microns for a coefficient of difference of 0.84 . Higher horizons show a greater coefficient of difference reaching 1.01 in the uppermost horizon ( $\mathrm{Du})$.

Microspheric and megalospheric specimens cannot be compared at the same volution, but it should be noted that microspheric specimens attain greater half lengths up to about $9 \mathrm{~mm}$ compared to $5 \mathrm{~mm}$ for the largest megalospheric specimens. 

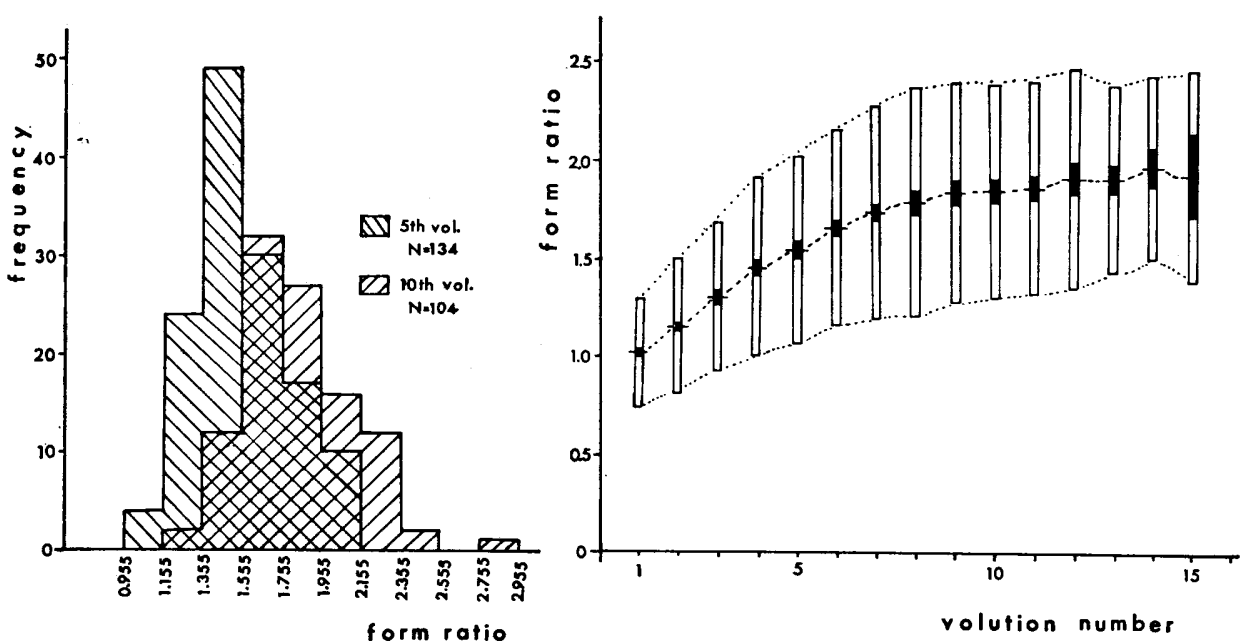

Fig. 10. A, Frequency distribution histograms of the form ratio for the 5th and 10th volutions of the megalospheric shell. B, Diagram showing the ontogenetic change and variation in the form ratio of the megalospheric shell. The vertical lines are two standard deviations, black rectangles represent the 95 per cent confidence limits for the mean, with a cross line at the sample mean (sample $F u$ ).

\section{G. Shell form (form ratio)}

Lepidolina multiseptata (DEPRAT) exhibits marked variability in shell form (form ratio). The shell form changes rapidly through the ontogenetic development (Fig. 10-B). Fig. 10-A shows the individual variation of the form ratio at the fifth and tenth volutions. The amount of individual variation is, as shown in the figure, fairly large. The observed range of this index for 41 megalospheric specimens of Sample $P b D u$, the topotypes of Lepidolina multiseptata (DEPRAT), for instance, varies from 1.57 to 2.74. The range of individual variation enlarges as the stratigraphic horizon becomes higher, as is evidenced by the increasing standard deviation (Fig. 12). The coefficient of variation for 28 samples varies from 7.31 to 22.45 , averaging 11.73 . The microspheric shells have a much larger form ratio than the megalospheric shells. The form ratio of the fully mature microspheric shells from the Middle Permian varies from 1.5 to 2.4. That of the microspheric shells from the Upper Permian varies from 2.0 to 3.5. Considerable geographic variation occurs in the form ratio of megalospheric shells. The form ratio is much more variable among the Upper Permian samples than among the Middle Permian ones. The coefficient of differences takes the maximum of 0.87 at this horizon. The difference of variance among samples is, however, not significant at 5 per cent level.

Lepidolina shell gradually shifts in shape from inflated fusiform to elongate fusiform (Figs. 11-13). A gradual increase in the form ratio is, despite the wide geographic variation, confirmed at five successive horizons of the Permian (Fig. 12). The increase of the form ratio can also be detected by the allometric analyses. As is shown in Fig. 11, the inclination of the allometric lines which show a relation between the radius vector (on the abscissa) and the half length (on the ordinate) becomes, as is indicated by the increase of a value, steeper towards the upper 


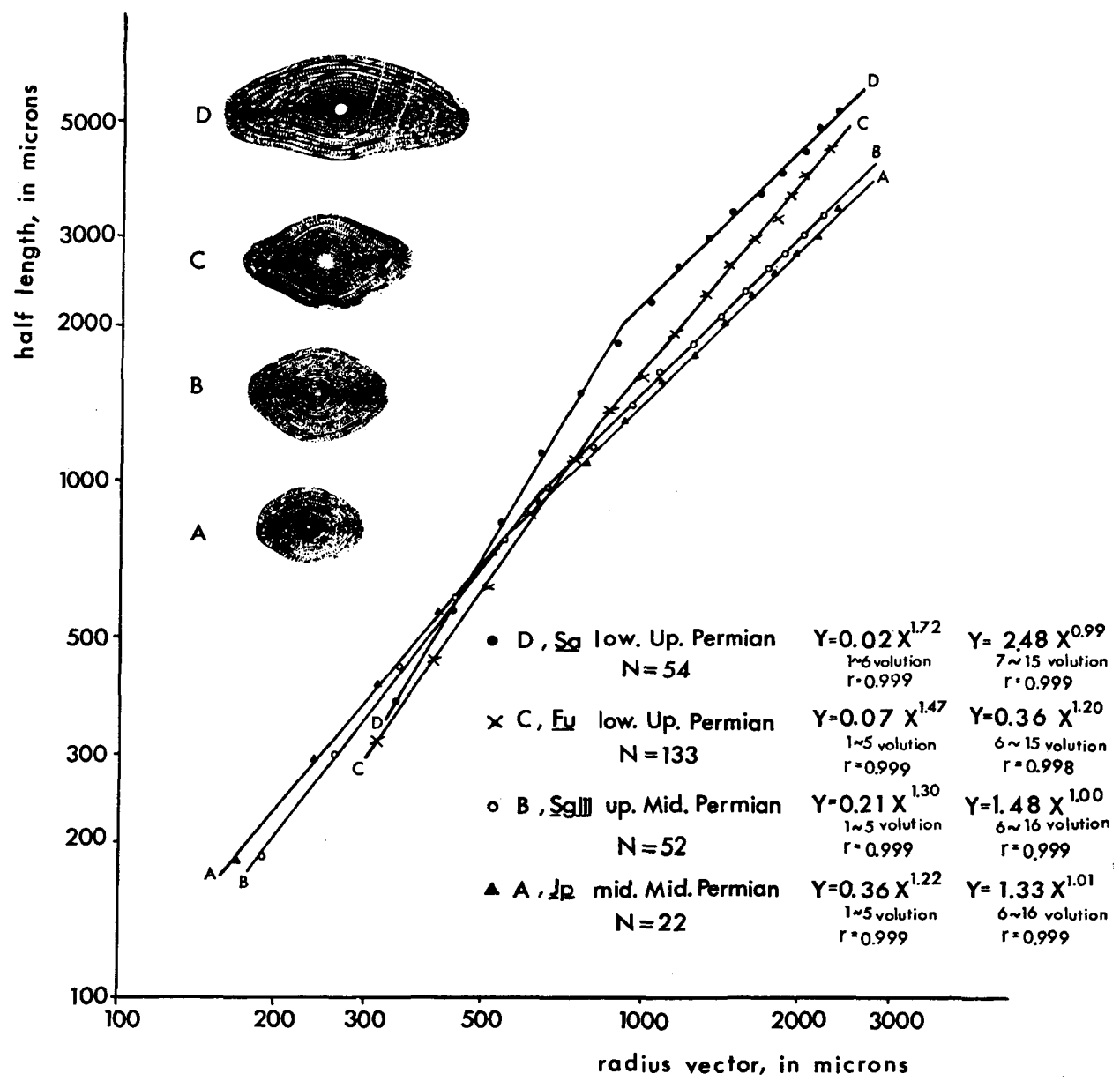

Fig. 11. Allometric plots for four representative samples of Lepidolina multiseptata from different stratigraphic horizons. The double logarithmic graphs show a serial change of average growth in megalospheric shells, indicating the change of growth ratio at about the sixth volution. The plots indicate the mean of the half length and radius vector in respective volutions.

stratigraphic horizons. The difference in the slope of the growth lines is always significant $(P<0.01)$. This means that the shell form is gradually elongated. The standard deviation of the form ratio of samples from the Upper Permian are about twice as much as those from the Middle Permian. Significant difference of variance is always recognized between the samples from the $\mathrm{Du}$ and other stratigraphic horizons. The maximum coefficient of difference of Sample Sa and Sample $J p$ is 1.90. With C. D. of 1.90, the two populations are separable from each other. The coefficient of difference of the form ratio for the microspheric shells of Sample $S g$ $I I I$ and Sample Fu is over 3.0. The microspheric specimens of the Upper Permian are easily distinguishable from those of the Middle Permain (Pl. 23, Figs. 16, 17 and Pl. 24, Fig. 14). 


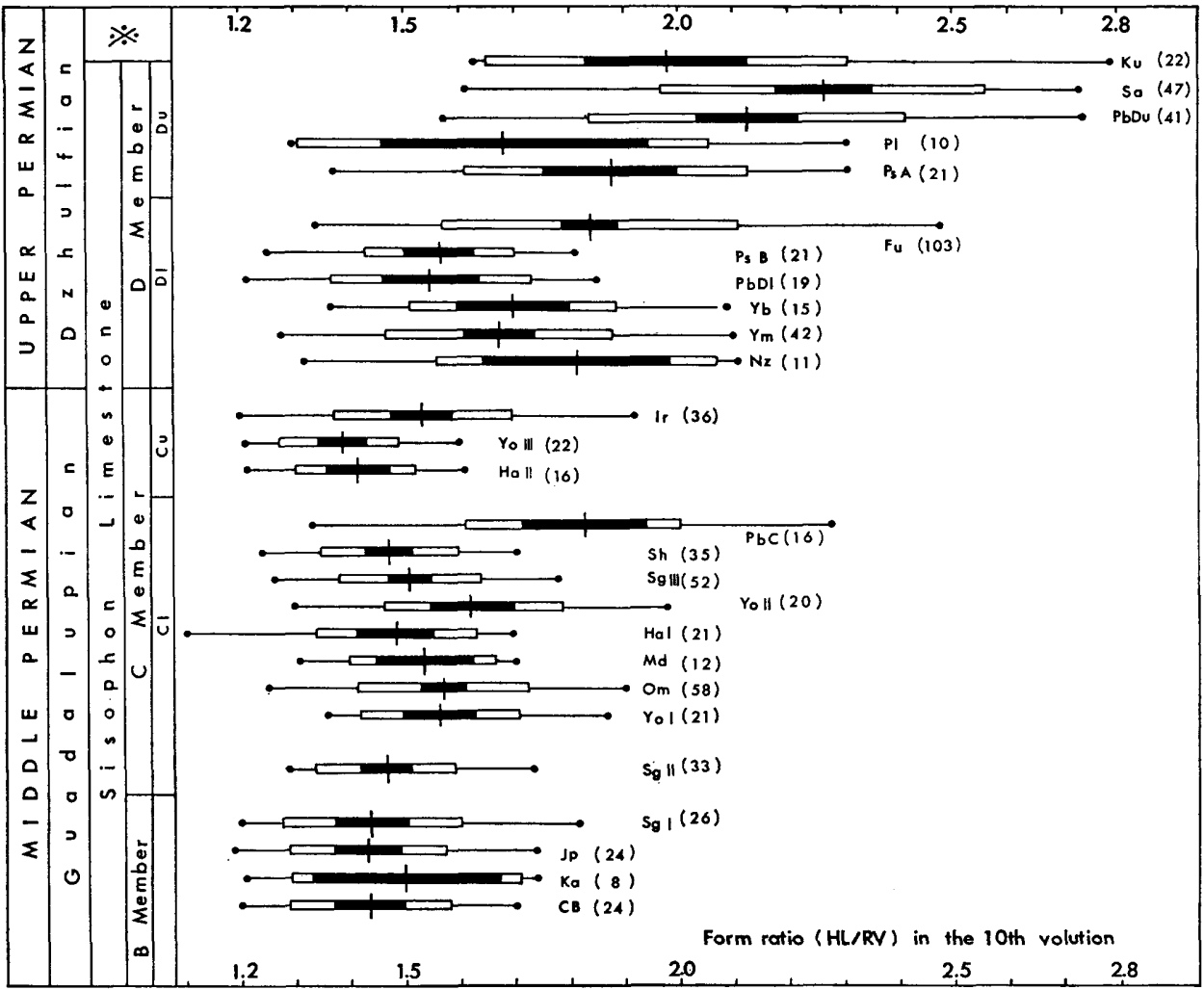

Fig. 12. Variation in the form ratio and chronologic change in successive populations of Lepidolina multiseptata. The explanation of figure is shown in Fig. 7.

\section{H. Height of volutions}

Except for several inner volutions of the immature stage, a considerable ontogenetic increase in the height of volution is not found. A fairly large amount of individual variation occurs in this dimensional character. The coefficient of variation of this character for 29 samples varies from 9.58 to 21.39 , averaging 14.58. Significant difference in the means of height of volution cannot be detected among the geographically and stratigraphically dfferent samples, although a slight difference exists.

\section{Spirotheca}

The spirotheca (=protheca) of Lepidolina multiseptata is composed of a tectum and a keriotheca that is commonly thin and has very fine alveoli (Fig. 3, $\mathrm{f} ; \mathrm{Pl} .26$, Fig. 9). The spirotheca is commonly thicker in specimens from the older horizons and thinner in the specimens from younger horizon. Within specimens it is commonly thicker in the mid volutions than in the outer volutions, but there is a considerable variation. The thickness tends to increase ontogenetically in the lower stratigraphic horizon (TORIYAMA, 1958, p. 247) and it tends to thin in the outer volutions, especially in the Upper Permian horizons (KANMERA, 1964, p. 20). The thinning of the keriotheca becomes extreme in some of the younger specimens, 
leaving only the thin dense tectum.

\section{Discussion}

As is evident in the size distribution of proloculus and other shell character, there occur two distinct forms in Lepidolina multiseptata (DEPRAT). The two forms correspond to gamont (megalospheric form) and schizont (microspheric form) seen in the reproductive cycle of a species. They are quite dissimilar as in many other foraminiferal species (DUNBAR, SKINNER and KING, 1936; DUNBAR, 1963 ; SCHAUB, 1963; OzAWA, 1970 ; etc.). Morphologically the megalospheric form is easily distinguished from the microspheric one (Pl. 23, Figs. 13, 15-17; Pl. 24, Fig. 14) in having a more inflated and smaller shell with a much larger proloculus and less numerous volutions. The former, as in many recent and fossil foraminiferal species, exceeds the latter in individual number within a population. Although relative frequency of the two forms varies considerably among samples, that of the microspheric form is nearly one per cent in many cases. It is only 0.7 per cent ( 7 microspheric individuals in 999 specimens), taking Sample Fu as an example. This may be explained by the formation of a large number of young embryos by reduction division of an adult schizont in the reproductive cycle of a foraminifer.

Foraminifers, as well as many other animals, change their shape in the course of the ontogenetic development. In Lepidolina multiseptata, age variation caused by allometric individual growth is much greater than other kinds of variation. As is mentioned in page 132 of this paper, the form ratio of a microspheric shell, for example, changes ontogenetically from about a unit value to more than 4 . This fact means that evaluation of growth stage of fossil organisms must, as a routine procedure, precede any interpretation of evolutionary development and/or comparison between samples (NEWELL, 1956, p. 76), although, as CUTBILL and FORBES (1967, p. 322) have suggested, it is, in general, not so easy to determine the mature stage in the ontogenetic development of the fusulininan foraminifers. Allometric analysis of Lepidolina multiseptata shells, has been made principally to evaluate the growth stages in ontogeny. Each specimen shows diphasic allometry in the relation between the radius vector and the half length of shell, although among individuals there is considerable variability in growth coefficient. The relation between the average radius vector and the half length in each consecutive volution of a sample corresponds to the straight lines on the double logarithmic graph, having a "critical point" near the sixth or seventh volution (Fig. 11). The shift in growth coefficient from highly positive allometry to nearly isometry or negative allometry takes place near the seventh volution in both the megalospheric and microspheric shells of most samples. It is evident that the array of secondary transverse septula becomes stable at this stage of shell growth. At the seventh or eight volution this foraminifer probably attain a mature stage. Based on these facts the analysis of individual variation and their comparison among samples have been made at the tenth or later volution of the mature stage.

Wide individual variation, added to the marked age variation, also occurs in shell characters in each volution that approximately represents a definite growth stage. Variation of the shell shape is the most apparent. Consequently the form ratio which is intimately related to the shell shape varies rather strikingly. The variability of mensural characters such as a radius vector and a half length is 
essentially continuous and normality of distribution can be recognized. A fairly large amount of intrapopulational variation occurs in these mensural character. The prolocular diameter is intimately related to the volume of embryonic cell with which the foraminifer begins its life. This may be independent of subsequent environmental influences. It has been used by many authors as an important criterion for taxonomic consideration of foraminifers. As is indicated by the great coefficient of variation ( $\mathrm{V}=15$ to 33 ), a marked individual variation occurs in this character within a single population or a sample of Lepidolina multiseptata. On the basis of the size of proloculus and some other characteristics, many authors have described two or more "species" of Lepidolina in a single sample from one and the same locality. As is clearly shown by the continuous variation which is unimodal and is regarded as a normal type of distribution, all those "species" may be no more than individual variants of a single species.

The number and nature of septula are relatively stable within a single sample and is considered to be an important taxonomic character in this foraminifer together with the prolocular diameter.

The present state of our knowledge does not permit us to explain clearly why these wide individual variations are displayed in this foraminifer. The striking individual variation in shell morphology is known in many foraminiferal species (AdAMS, 1957, LeE et al., 1963, Gordon, 1966, Douglass, 1970, SANDERson and VERVILLE, 1970, OzAWA, 1970, etc.). It seems rather difficult to reasonably explain the wide variation in certain characters from the standpoint of ecological ground such as nutrition. It has been well known that the foraminifers have a rather complicated life history (ARNOLD, 1955, MYERS, 1937, 1940, LEE et al., 1963, etc.). According to ARNOLD (1955), eight distinctive animal types are theoretically recognized in the foraminiferal life cycle of a species. The combination of three principal characters, number of nuclei, the number of chromosome sets and the process in life cycle, produces the eight polymorphic types. In a series of laboratory studies LEE et al. (1963) concluded that morphological and size variation are correlated with nutrition and the life cycle. The frequency distribution of variabilities analyzed by biometric techniques is considered to be the composite of several animal types, although the histograms do not show any distinct polymodality either in megalospheric or microspheric forms. Furthermore each sample is likely to contain individuals which are a great number of generations apart. It is sometimes known that the histograms of prolocular distribution in megalospheric form are a little skewed to the right or positively. This tendency may be due to the great variability of this characters which may be caused by the reasons mentioned above but possibly also to the slight shift of the sectioned plane from the real axis of the shell. Recently KAESLER and WATERS (1972) tried to explain this phenomenon by the difference of mortality among individuals with different shell and prolocular diameter. As is presented by Sample Fu in Fig. 4, the frequency distribution histograms of prolocular diameter of Lepidolina multiseptata is slightly skewed. However, except for a few samples which may contain populations of a considerable chronologic aggregates, the skewness is not so marked in the samples studied as we need to transform the prolocular diameter into logarithmic scale, although, in a very strict sence, log-normal type of distribution may be statistically expected in the frequency distribution of the prolocular diameter. In this study the statistical discussion on prolocular diameter is, by the reason mentioned above, carried out based on the normal distribution. Anyhow the wide individual varia- 
tion in prolocular diameter and some other characters may be largely due to the polymorphism in life cycle and the integration of a large number of generations in a sample.

It is noteworthy that the geographic variation is slight in some shell characteristics. In spite of the wide individual variation, the difference between the mean proloculus size in two samples from synchronous horizons is always insignificant at 5 per cent risk level (Fig. 5). The analogous situation is also in the number of axial septula (Fig. 7). These characters must be controlled largely by the genetic system and may be evaluated as taxonomically important characters. An fairly large amount of interpopulational variation occurs in several characters such as radius vector, half length and shell form. These characters may be controlled considerably by environmental factors as well as the genetic system. It should be emphasized that, despite the wide geographic distribution of the foraminifer, there is little clinal variation. It is of interest to examine the peculiar pattern of geographic variation analyzed in this foraminifer in relation to climatic condition and the meanings of dispersal. Many taxonomists have observed and discussed clinal variation in many continental species, but rarely in marine organism. There are some good examples of clines in recent shallow marine foraminifers. Nonionellina flemingi (VELL), a benthonic foraminifer living on the continental shelf off New Zealand is an excellent example (LEWIS and JENKINS, 1969). In this species size and number of chambers of the final whorl are gradually increased from the lower latitude to the higher, in accordance with gradual decrease of water temperature on the bottom where the foraminifers lived. In this case the authors considered the temperature as the most effective environmental factor in producing the clinal variation in the foraminiferal species, as already confirmed by BRADSHow (1957) in laboratory studies of Ammonia beccari var. tepida and also by NICOL (1940) in natural populations of Elphidium off the West American coast. As far as we know, the clinal variation has been confirmed by the benthonic foraminifers living on clastic sediments in rather high latitude where the average annual water temperature changes considerably in slight differences of latitude and therefore the temperature gives a strong selective effect on local populations of foraminiferal species.

In tropical and subtropical climates, where the seasonal flutuation in the water temperature of shallow sea is extremely small (MAXWELL, 1968, etc.), the situation may be quite different from that in areas of higher latitudes. In these areas the temperature may give no powerful selective effect on the production of clinal variation. The thick pile of shallow carbonate sediments is well developed usually as coral reefs in the tropical and subtropical areas embraced between $18^{\circ} \mathrm{C}$ isotherms for the minimum water temperature in winter season (NEwELL and RIGBY, 1957, etc.). Many larger benthonic foraminifers are adapted to the shallow carbonate facies of these seas. In the reef facies, foraminifers are extremely sensitive to environmental influence (MAXWELL, 1968, p.171). Alveolinella quoyi (d'ORBIGENY), which is closely similar in morphology to Lepidolina multiseptata, is restrictedly known on the off-reef shelf at a depth of 10 to 80 meters (REICHEL, 1964 , p. C505, BANDY, 1964, p. 80, MAXWELL, 1968, p. 174). In this kind of species which occupy a uniform habitat situation, relative genetic homogeneity would be expected.

The predominance of limestone deposition over the world in the Permian age apparently implies that warm shallow seas and tropical and subtropical climates 
covered wide areas of the earth (RODGERS, 1957, etc.). As THOMPSON (1964) mentioned, it is fully realized that the fusulinid foraminifers including Lepidolina multiseptata were bottom-dwellers under shallow waters where they probably lived at depths that were moderately uniform in temperature and other physical environments at almost all latitudes. As has been explained in the former chapter, Lepidolina multiseptata occurs in many, if not all, cases in the Permian shallow carbonate sediments which are sometimes interpreted as the deposits of reef environments (OTA et al., 1969, IsHII et al., 1969). The slight geographic variation in Lepidolina multiseptata may be largely due to uniform habitat situation, although a progressive change in adaptive zone with time may be conceivable (OzAWA, 1970, fig. 1). Furthermore it is well known in many benthonic foraminifers that the young embryos pass through a pelagic phase before the beginning of their benthonic life (LOEBLICH and TAPPAN, 1964, C71-C86). This means that the dispersal of these foraminifers may be so rapid as to cover extensive geographic areas in a relatively short time. Many species of the extinct suborder Fusulinina have been treated as very reliable guide fossils in the Permian and Carboniferous. Many stratigraphic data evidently show that the dispersal of species of the Fusulinina were rapid (Ross, 1962, etc.). The rapid dispersal may be one of the reasons why Lepidolina multiseptata shows slight geographic variation. As a principle, the rapid gene flow caused by rapid dispersal would tend to make the gene frequency of all population nearly homogeneous. To explain the absence of geographic variation, MAYR (1963, p. 304) has already mentioned in his comprehensive work that "the means of dispersal are so great that the species is almost panmictic, regardless of the geographic extent of its range."

To sum up the results of analyses in the preceding chapter, a progressive change with time can be concluded in the following ways (see Figs. 5, 7, 12 and 13).

1) In general shell is gradually enlarged.

2) Shell changes from a highly inflated fusiform to a more elongate one.

3) Thickness of spirotheca progressively decreases.

4) Proloculus (embryonic chamber) progressively increases is volume.

5) Number of axial septula gradually increases.

6) The first appearance of secondary transverse septula becomes progressively accelerated.

The pattern of transformation in time is essentially continuous and show one-way trend (HenNingsmoen, 1964, p. 342). Simpson (1944, p. 202) called this mode of evolution phyletic evolution. Excellent examples showing one-way evolutionary trend has been recognized in Liassic oysters, Gryphaea series, Cretaceous sea urchins, Micraster, Carboniferous corals, Zaphrentites delanouei series, and several other extinct organisms. This mode of evolution is common in some extinct larger foraminifers; Nummulites and Assilina from Paleogene of Europa (SCHAUB, 1963), Fasiolites from Eocene of Europa (HoTTINGER, 1963) and Lepidocyclina from Oligocene and Miocene of Java (VAN der VLERK and GLOoR, 1968) which had their nitches in shallow carbonate sedimentary facies as in Lepidolina.

A question remains as to what kind of selective force could have effected over a long series of generations to result in a progressive shift of populations in oneway direction. It seems difficult to accept that the temperature and salinity consistently changed in a definite trend. The stratigraphic evidence does not indicate any gradual change in lithologic facies but shows rather rapid occupation of deeper clastic sedimentary facies instead of shallow carbonate sedimentary facies at the 


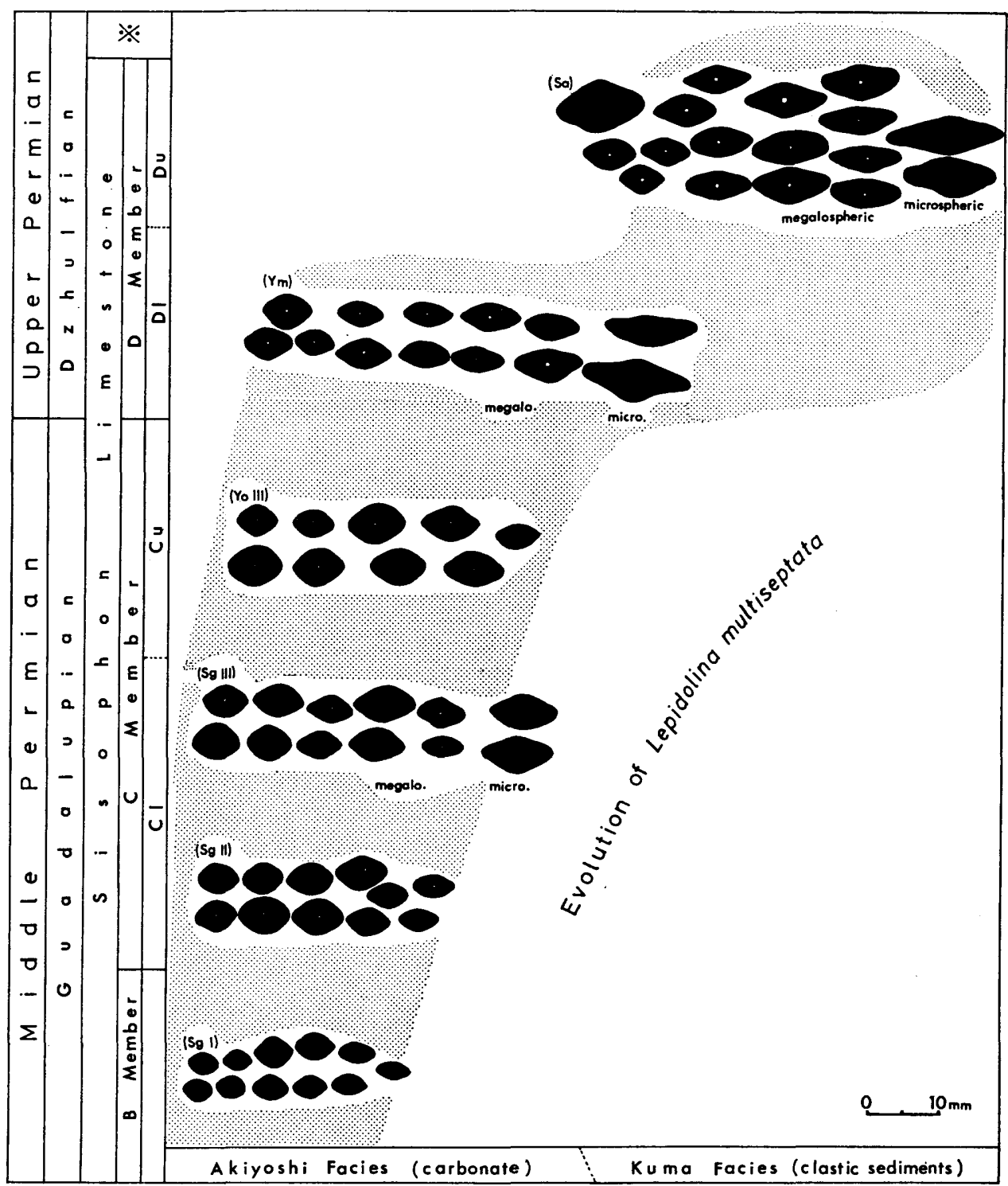

Fig. 13. Individual variation in the shell form and prolocular diameter, and their chronologic transformation in Lepidolina multiseptata.

end of the Middle Permian age. In accordance with the change in lithofacies gradual displacement of habitat may have taken place. The evidence indicates that the adaptive zone of Lepidolina multiseptata shifted from shallow carbonate sedimentary facies to deeper clastic sedimentary facies (OzAWA, 1970, fig. 1; Fig. 13). The species in most cases occurs in relatively thick limestone throughout the Middle Permian, while it commonly occurs in small limestone lenses of less than $1 \mathrm{~m}$ thick intercalated in black shale of the Upper Permian. As the displacement of habitat may have produced some ecological change for the species, gradual change in genetic make-up of populations might have occurred. In the Lepidolina 
multiseptata lineage, the phenotypes with a larger and more elongate fusiform shell were evidently adapted to the environment of black shale facies and might have been more advantageous than those with a small and inflated one for the environmental selection. And in accordance with the increase of a clastic sedimentary facies in the Late Permian the populations, as a phenomenon, shifted in structure from individuals with an inflated shell to those with larger and more elongata shell which has more numerous septula and chamberlets. The correlation of foraminiferal shell form, size and structure with environments is an important and interesting problem in the consideration of evolution of benthonic foraminifers and to be studied more (BANDY, 1964).

It is finally emphasized that the current concept of basic mechanism in evolution, random mutation, recombination and accumulation of numerous small genetic changes in population through environmental selection, may be acceptable in these extinct foraminifers which show a gradual change in one-way direction.

\section{Taxonomic Notes}

Taxonomists can reasonably give a specific name to the branching in an evolving sequence of an extinct organism but can only arbitrarily define species in the segment of a phyletic stem, because species are evolving systems and there is no objective way to subdivide a continuous lineage. (MAYR, 1969, p. 35)

In the Lepidolina multiseptata lineage, the specimens from populations of Late Permian differ from those of Middle Permian populations so much that many paleontologists would regard it as a distinct species. However, the sequence of populations seem to constitute an "evolutionary" species, Lepidolina multiseptata (DEPRAT, 1912) as described hereafter. Three transients (transient; neutral term for the convenience of biostratigraphic application; BATHER, 1927, p. 87; SYLVESTER-BRADLEY, 1951, p. 93; 1956, p. 142; THOMAS, 1956, p. 29 ; =mutation of WAAGEN's sense) of this species are arbitrary define and described in this chapter, taking the stage of evolutionary development in important shell characteristics, prolocular diameter, number and features of septula, and stratigraphic horizons into consideration. The coefficient of difference of 1.28 is applied to determine conventional level of transient distinction in the successive lineage of Lepidolina multiseptata. As is described in the former chapter, the coefficient of difference between the extreme samples of the lineage varies from 2.7 to 4.0 in important characters (Fig. 8).

\section{Order Foraminiferida}

Suborder Fusulinina WEDEKIND, 1937

Superfamily Verbeekinoidea STAFF and WEDEKIND, 1910

Family Neoschwagerinidae DUNBAR and CoNDRA, 1928

Subfamily Lepidolininae Miklukho-Maklay, 1958 emend. OzaWa, 1970

Genus Lepidolina LEE, 1933, emend. OzAWA, 1970

[Pseudoyabeina TumansKaya, 1954; Gublerina Minato and HoNJo, 1959; Kumaella CHISAKA, 1960 (nomen nudum) ] 
Type-species.-Neoschwagerina (Sumatrina) multiseptata DEPRAT, 1912. Generic diagnosis.-See OzAWA, 1970, p. 49.

Lepidolina multiseptata (DEPRAT, 1912)

Pl. 22-26.

Specific diagnosis.-Medium to large-sized species of Lepidolina, characterized by well developed secondary transverse septula and axial septula which are somewhat irregular in shape and size. Distinct dimorphism recognizable. Mature megalospheric shells of fifteen or more volutions inflated to elongate fusiform, having a very large proloculus. Microspheric form has a very large fusiform to elongate fusiform shell of twenty or more volutions.

Comparison and remarks.-As far as we know, the genus Lepidolina comprises three distinct species, Lepidolina multiseptata (DEPRAT), the type-species, $L$. kumaensis KANMERA, 1954 and L. japonica (FUJIMOTO, 1936). Lepidolina minuta (THOMPSON and WHEELER, 1942) and the species referred to as Yabeina columbiana (DAWSON) by several Japanese authors may be conspecific with Lepidolina multiseptata. The following species which usually occur in association with Lepidolina multiseptata in the same samples from the same localities are merely individual variants of Lepidolina multiseptata (DEPRAT), because the normal type of frequency distributions are, as the result of biometric analysis, confirmed in taxonomic characters and the studied samples cannot be taxonomically subdivided.

Yabeina yasubaensis TORIYAMA, 1942

Yabeina gubleri KANMERA, 1954

Yabeina khmeriana SAURIN, 1958

Yabeina johannis SAURIN, 1958

Yabeina pinguis TORIYAMA, 1958

Four species of Neoschwagerina described by LANGE (1925) from a locality of Sumatra are, as IsHII and NoGAMI (1964) claimed, considered to be conspecific with Lepidolina multiseptata.

Lepidolina kumaensis KANMERA is closely allied to L. multiseptata and might be a descendant of the latter species (OzAWA, 1970, fig. 13). The former is distinguished from the latter in having a more elongate shell, thinner spirotheca and many well developed secondary septula which are regular in shape and size. It occurs restrictedly in the Upper Permian of the Japanese Islands and Sikhote Alin area of the Far East of U.S.S.R. Lepidolina japonica (FUJIMoTo) somewhat resembles $L$. multiseptata, but differs from the latter in having a different shaped shell with less numerous volutions, smaller proloculus and different pattern of secondary transverse septula. Lepidolina japonica is known to occur in the upper Middle Permian of the Outer Zone of Southwest Japan.

Lepidolina multiseptata comprises three transients; asiatica (IsHII, 1966), shiraiwenis (OzAWA, 1925) and multiseptata (DEPRAT, 1912) in descending order.

Lepidolina multiseptata (DEPRAT) transient asiatica IsHII, 1966 Pl. 22, Figs. 1-11, 15; Pl. 26, Figs. 1, 4

1964. Yabeina sp. cf. Y. tobleri (LANGE) ; IGo, p. 64-65, Pl. 2, figs. 4-5.

1966. Yabeina asiatica IsHII, p. 133-134, pl. 5, figs. 1-6.

1966. Yabeina sp. cf. Yabeina columbiana (DAwsoN); IsHII, pl. 6, fig. 1. 
1966. Neoschwagerina douvillei OzAWA; IsHII, pl. 5, fig. 4.

? 1966. Neoschwagerina sp.; IsHII, pl. 5, figs. 7, 8. 2-11, pl. 47, figs. 1, 2.

Characters.-Shell medium, inflated fusiform, having bluntly pointed to rounded poles. Proloculus moderate; its outside diameter ranges from about 120 to 400 microns in megalospheric form, with average diameters of 200 to 250 microns. Mature shells of 13 to 16 volutions about 5 to $6 \mathrm{~mm}$ in length and 4 to $5 \mathrm{~mm}$ in width. Form ratio usually varies from 1.2 to 1.8 , averaging 1.4 or so. Secondary transverse septula first appear mostly at fourth and fifth volution. Axial septula between adjacent septa gradually increase ontogenetically. 3 to 6 axial septula between septa in the tenth volution. Spirotheca composed of a tectum and a moderately thick keriotheca with fine alveoli, and about $\mathbf{1 5}$ microns or so in an outer volution.

Distribution.-Lepidolina multiseptata transient asiatica occurs in the middle to upper Middle Permian limestones of Southeast Asia including Malaya and Cambodia, the Japanese Islands, and probably also British Columbia in Canada. In these areas it comes from limestone beds just above the bed with Colania douvillei and Neoschwagerina margaritae.

Paleoecological environment.-L. $m$. transient asiatica, as far as is known, occurs rather sporadically in gray to black calcareous algae foraminiferal biomicrite with a very fine lime-silt to -clay matrix which may denote deposition under a warm and calm shallow sea environment. It is associated with many other foraminifers including Sumatrina annae VoLz, Verbeekina verbeeki (GEINITZ), Chusenella spp., Kahlerina sp., Pachyphloia spp. and Hemigordius sp.

Remarks.-Specimens of samples $C B, K a, J p$ and $S g$. I belong to Lepidolina multiseptata transient asiatica IsHII.

Lepidolina multiseptata (DEPRAT) transient shiraiwensis OzAWA, 1925 Pl. 22, Figs. 12-14, 16-22; Pl. 23, Figs. 1-17; Pl. 26, Figs. 2, 5

? 1922. Yabeina hayasakai OzAwA, p. 369-370, pl. 4, fig. 2.

1924. Neoschwagerina craticulifera HAYASAKA (partin) [non SchWAGER, 1883], p. 18-19, pl. 3, fig. 8.

?1925. Neoschwagerina (Yabeina) hayasakai, OzaWA, p. 61-62, pl. 10, fig. 5 . 1925. Yabeina shiraiwensis OzAwA, p. 63, 64, pl. 2, figs. 2b, 5c, 7b; pl. 10, figs. 1, 2. 1925. Yabeina shiraiwensis, OzAWA, pl. 3, fig. 8, pl. 4, figs. 1-3 (without descrip-

\section{Explanation of Plate 22}

All figures $\times 6.6$

Figs. 1-11, 15. Lepidolina multiseptata (DEPRAT) transient asiatica ISHII .........................................Page 151 $1-3,15$, specimens in sample $S g I .4$, specimen in sample $C B .5-10$, specimens in sample $J p$. 1-6, 9-11, axial sections of megalospheric shell. 7,8 , 15, sagittal sections of megalospheric shell.

Figs. 12-14, 16-22. Lepidolina multiseptata (DEPRAT) transient shiraiwensis

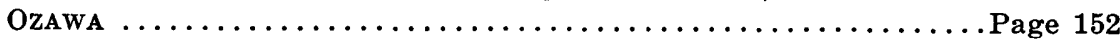
$12-14,16,20,21$, specimens in sample $S g I I .18,19$, specimens in sample $M d$. 22 , specimen in sample TeL, JPE-10364. 12-14, 16, 17, 19, 20, 22, axial sections of megalospheric shell. 17,18, 21, sagittal sections of megalospheric shell. 

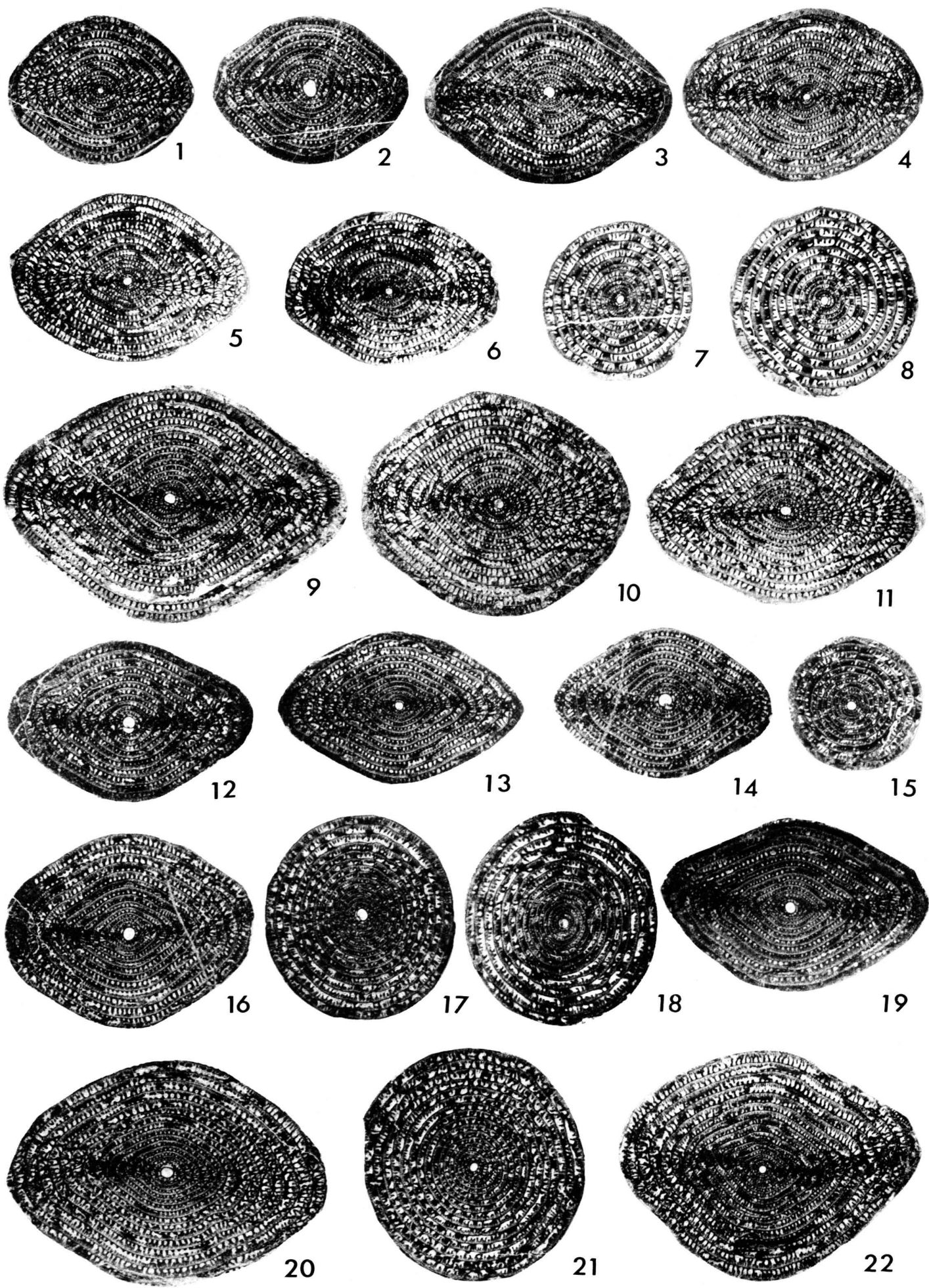

T. OzAWA: Evolution of Lepidolina multiseptata 

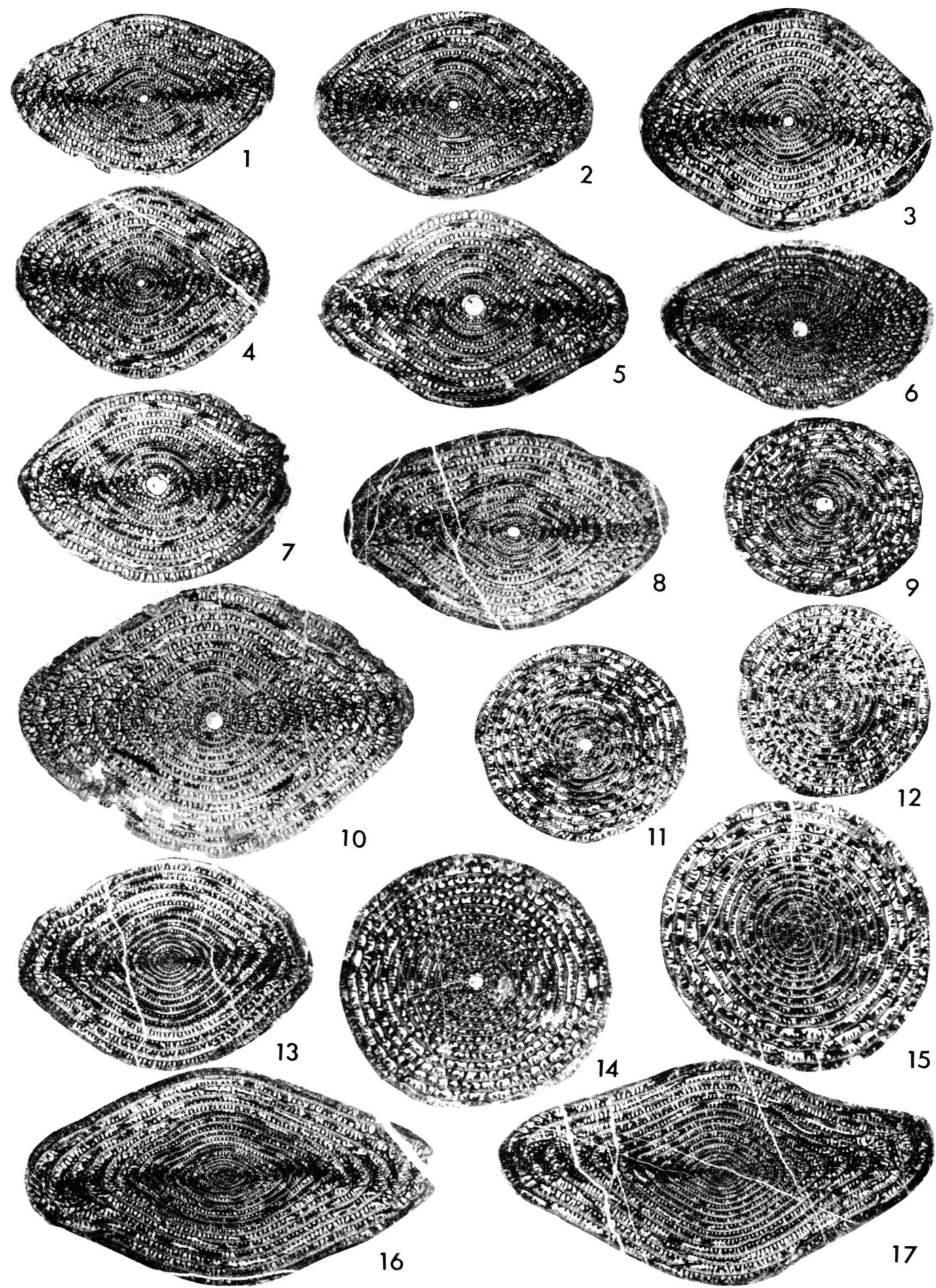

T. OzaWA: Evolution of Lepidolina multiseptata 
tion).

1936. Yabeina shiraiwensis, Hujıмото, p. 122, 123, pl. 26, figs. 1-7.

1942. Yabeina shiraiwensis, ToriYama, p. 245 , pl. 24 , figs. 14,15 ; pl. 25, figs. 1-6.

1956. Yabeina shiraiwensis, CHEN, p. 64, 65, pl. 14, figs. 8-10.

1956. Yabeina shiraiwensis, MoRIKAWA, p. 254-256, pl. 33, figs. 1-11; pl. 34, figs. 8-9.

1956. Yabeina akiyamai, MorikawA, p. 256-258, pl. 34, figs. 1-7.

1958. Yabeina shiraiwensis, TORIYAMA, p. 236-241, pl. 44, pl. 45, figs. 1-11.

1958. Yabeina yasubaensis ToriYama, p. 241-244, pl. 45, figs. 12-14; p1. 46, figs. $1-12,15,16$.

1958. Yabeina pinguis Toriyama, p. 244-247, pl. 47, figs. 1-8.

1958. Yabeina sp. cf. Y. tobleri (LANGE); TORIYAMA, p. 233-236, pl. 43, figs. $15-18$.

1958. Yabeina sp.; TORIYAMA, p. 247-250, pl. 47, figs. 9-14.

1958. Yabeina shiraiwensis, MonIKawa et al., pl. 6, figs. 9, 10.

1960. Yabeina hayasakai, Igo, p. 335-343, pl. 36.

1960. Yabeina shiraiwensis, CHISAKA, p. 248, 249, pl. 5, figs. 1-10.

1960. Yabeina shiraiwensis, MoRIKAWA, p. 296, 297, pl. 53, figs. 1-9.

1961. Yabeina shiraiwensis, KAWANo, p. 112-116, pl. 13, figs. 12-14, pl. 14.

1961. Yabeina sp.; KawaNo, p. 116, 117, pl. 15, figs. 1-2.

1962. Yabeina shiraiwensis, IsHII and NogAMI, p. 64-66, pl. 1.

1963. Yabeina multiseptata (DePrat) ; Hanzawa and MurAta, pl. 1, fig. 7, pl. 5, pl. 6, figs. 1-4, 9.

1964. Yabeina multiseptata shiraiwensis, IsHII and NogAMI, pl. 5, figs. 1, 3.

1966. Lepidolina shiraiwensis, HASEGAWA, pl. 1.

1966. Yabeina dunbari SKINNER and WILDE, p. 51-52, pl. 43, figs. 1-6.

1970. Lepidolina multiseptata shiraiwensis, OzAWA, pl. 7, figs. 1, 2.

1970. Yabeina (Lepidolina) multiseptata shiraiwensis, CHоI, p. 350, 351, pl. 15, figs. 4-6.

non 1956. Yabeina shiraiwensis, SHENG, p. 221, 222, pl. 4, figs. 1-3.

Characters.-Megalospheric shell medium to large, inflated to normal fusiform. Mature shells of 14 to 17 volutions about 6 to $9.5 \mathrm{~mm}$ in length and 3.5 to $6.5 \mathrm{~mm}$ in width, giving form ratio of about 1.2 to 1.9 , mostly 1.4 to 1.6. Proloculus moderate to large. Its outside diameter varies from 130 to 680 microns, having average diameter of 290 to 390 microns. Spirotheca consists of a tectum and a relatively thin keriotheca. Its thickness about 10 to 14 microns in outer volutions

\section{Explanation of Plate 23}

All figures $\times 6.6$

Figs. 1-17. Lepidolina multiseptata (DEPRAT) transient shiraiwensis OzAWA

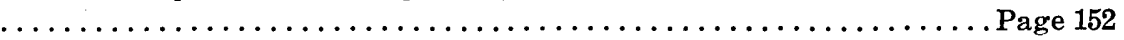
$1-4,9,11,12,16,17$, specimens in sample $S g I I I .5$, specimen in sample Yo $I I$. $6,7,10$, specimens in sample $S h: 6$, this specimen was originally illustrated by OzAwA (1925, pl. 10, fig. 2) and designated the lectotype of Yabeina shiraiwensis by TORIYAMA (1958, p. 236). 7, axial section, JPF-10501. 10, axial section, JPF-10309. 8, specimen in sample $O m$. 13, specimen in sample TeM, JPF-10372. 14, specimen in sample Yo III. 15, specimen in sample Ha I. 1-8, 10,13 , axial sections of megalospheric shell. $9,11,12$, sagittal sections of megalospheric shell. 13, 16,17, axial sections of microspheric shell. 15, sagittal section of microspheric shell. 
of mature stage. In most cases secondary transverse septula first appear in the third to fourth volution. Number of axial septula relatively large. 4 to 8 axial septula occur between adjacent septa in the tenth volution. Microspheric shell large, inflated to slightly elongate fusiform. Juvenile volutions lenticular in form with a short axis of coiling. Mature individuals contain as many as 20 volutions and about 9 to $12 \mathrm{~mm}$ long and 4.5 to $7 \mathrm{~mm}$ wide, giving form ratios of 1.6 to 2.4.

Distribution.-Lepidolina multiseptata transient shiraiwensis OzAWA is a transitional transient between asiatica and multiseptata in the Lepidolina multiseptata lineage. It occurs in beds between those of Lepidolina multiseptata transient asiatica and $L . m$. transient multiseptata in the upper part of the Middle Permian to the lower part of the Upper Permian of Southeast Asia, South China, the Japanese Islands and the Pacific Northwest of North America.

Paleoecological environment.-Lepidolina multiseptata transient shiraiwensis OzAwA occurs in crowds in calcareous algae foraminiferal biomicrite with a fine calcareous-silt or clay matrix. It is usually in association with the following foraminifers; Sumatrina annae "longissima" DEPRAT, Verbeekina verbeeki (GEINITZ), Chusenella spp., Dunbarula sp., Kahlerina spp., Pachyphloia sp. and other foraminifers.

Remarks.-Specimens of samples Sh, Sg II, Sg III, Yo I, Yo II, Yo III, Ha I, Ha II, Ir, Md, TeL, TeM, TeU, Om, Iw I, Iw II, Iw III, and PbC belong to Lepidolina multiseptata transient shiraiwensis OzAWA.

Lepidolina multiseptata (DEPRAT) transient multiseptata DEPRAT, 1912 Pl. 24, Figs. 1-15; Pl. 25, Figs. 1-10, Pl. 26, Figs. 3-11

1912. Neoschwagerina (Sumatrina) multiseptata Deprat, p. 53-55, pl. 3, figs. 2-8.

1914. Sumatrina multiseptata, DePRAT, p. 34, 35, pl. 5, figs. 7-11, pl. 6, figs. 1-3.

1924. Neoschwagerina multiseptata, CoLANI, p. 154, 155, pl. 15, fig. 1 ; pl. 24, figs. 12 , 13; pl. 25, figs. $1-8,10-12,14,15$; pl. 26, figs. $1,2,4,6-18$.

1925. Neoschwagerina tobleri LANGE, p. 209, 210, pl. 4, figs. 69a, b, c, d.

1925. Neoschwagerina staffi LANGE, p. 210, 211, pl. 3, fig. 70.

1925. Neoschwagerina buxtorfi LANGE, p. 211-213, pl. 4, fig. 71 .

1925. Neoschwagerina sumatrensis LANGE, p. 213 , pl. 4, figs. $72 \mathrm{a}, \mathrm{b}$.

1935. Neoschwagerina multiseptata, GuBleR, p. 119-123, pl. 3, fig. 5; pl. 6, figs. $1,3,8-10 ;$ pl. 7 , fig. 5 .

1935. Neoschwagerina multiseptata var. gigantea GUBLER, p. 116-118, pl. 3, figs.

\section{Explanation of Plate 24}

All figures $\times 6.6$

Figs. 1-15. Lepidolina multiseptata (DePrat) transient multiseptata DePrat ............................................... Page 154 1,2 , specimens in sample $Y b ; 2$, axial section of the lectotype of Yabeina yasubaensis TORIYAMA. This specimen was originally illustrated by TORIYAMA (1942, pl. 25, fig. 13) . 3, specimen in sample $P b D l$. 4, specimen in sample $Y m$. 5 , specimen in sample $N z$, slide number T1000/f1026 of New Zealand Geological Survey. 6, Holotype of Yabeina gubleri KANMERA, 1954. 8, specimen in sample $P b D u$. 9-15, specimens in sample $F u$. Marked intrapopulational variation occurs in the shell shape and size, and the prolocular diameter. 14, axial section of microspheric shell. 15, sagittal section of megalospheric shell. 

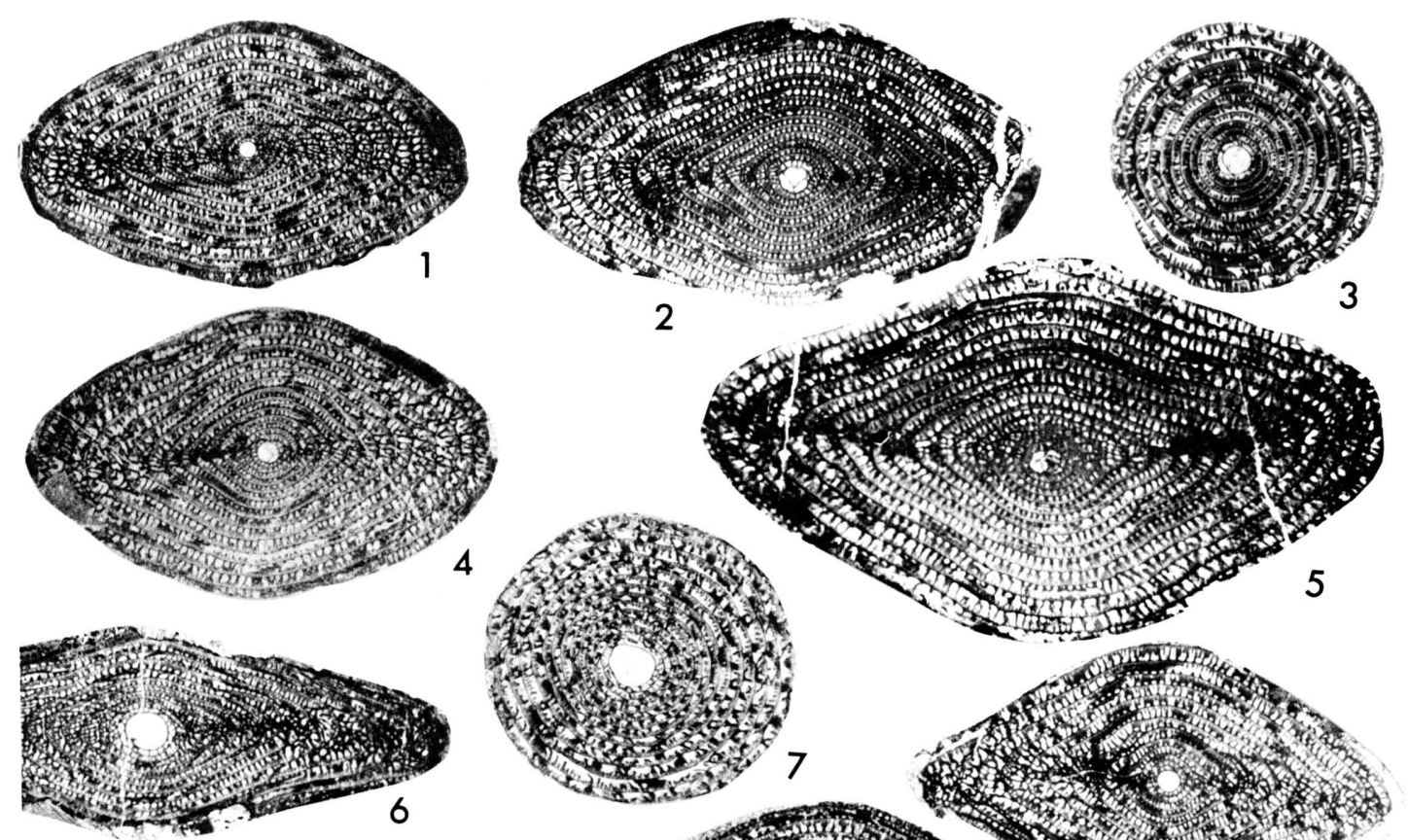

000

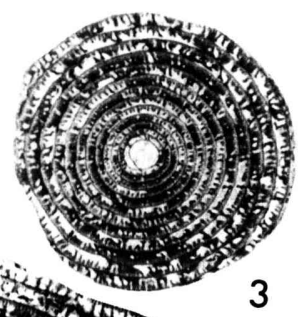

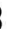

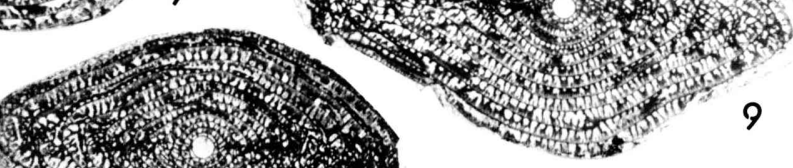

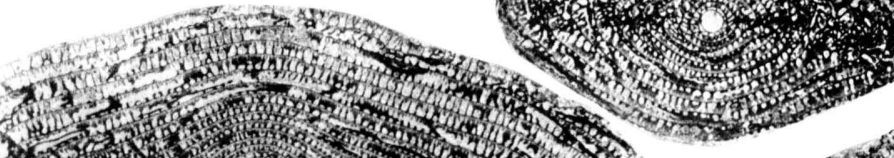

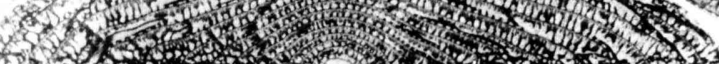
(3)

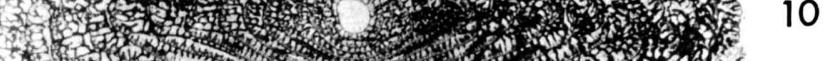

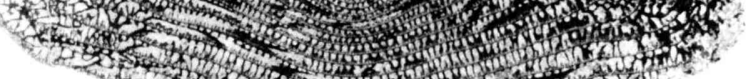

8
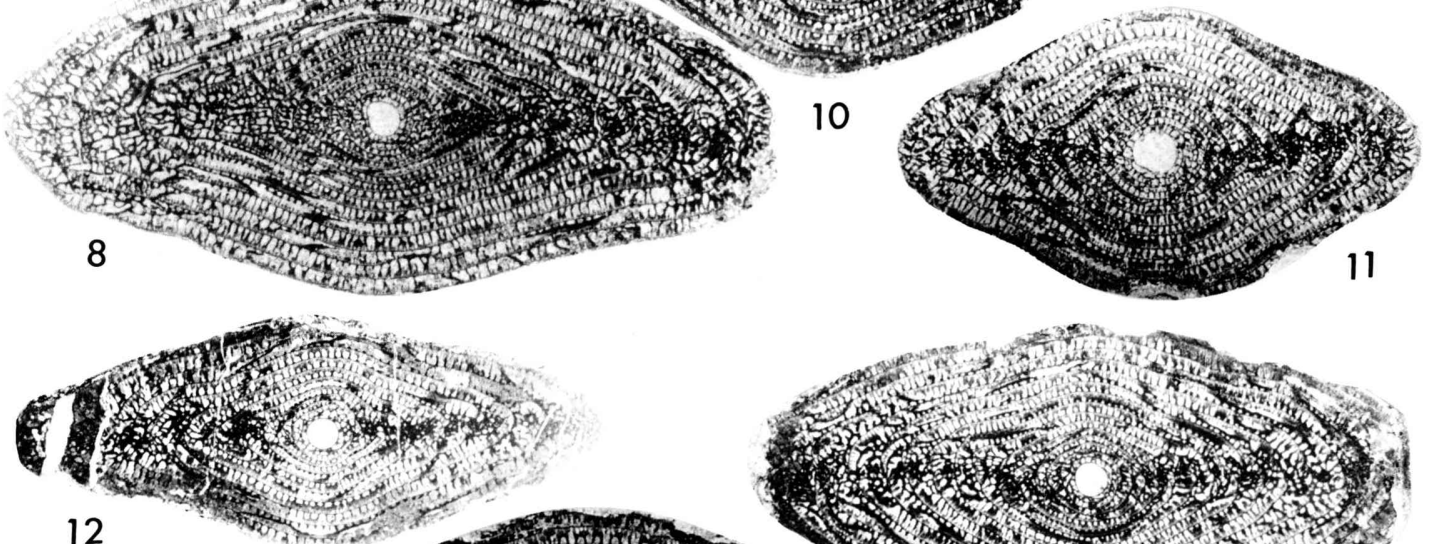

12
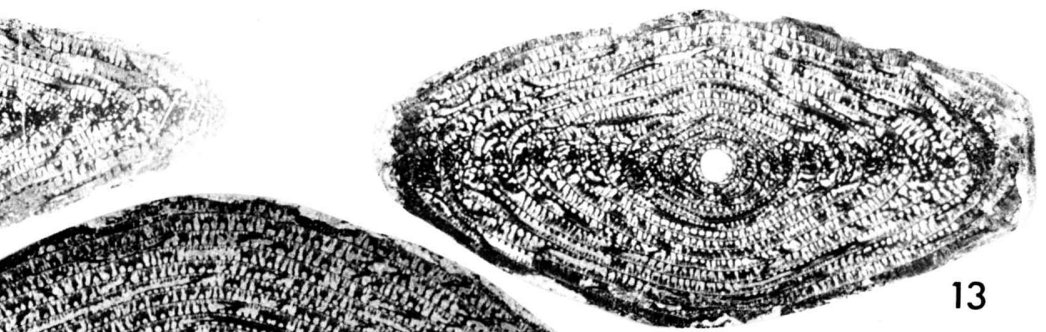

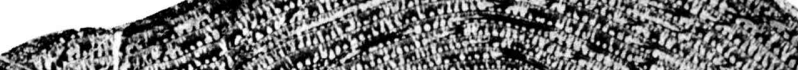

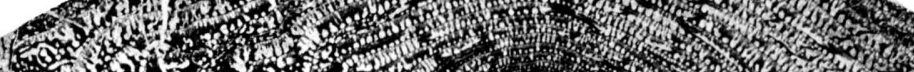

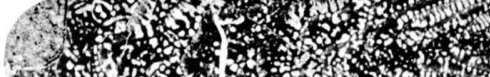

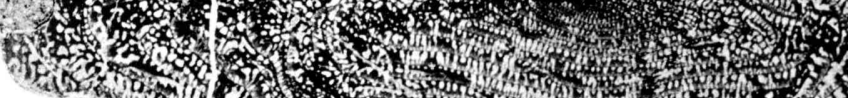

द.

14

4
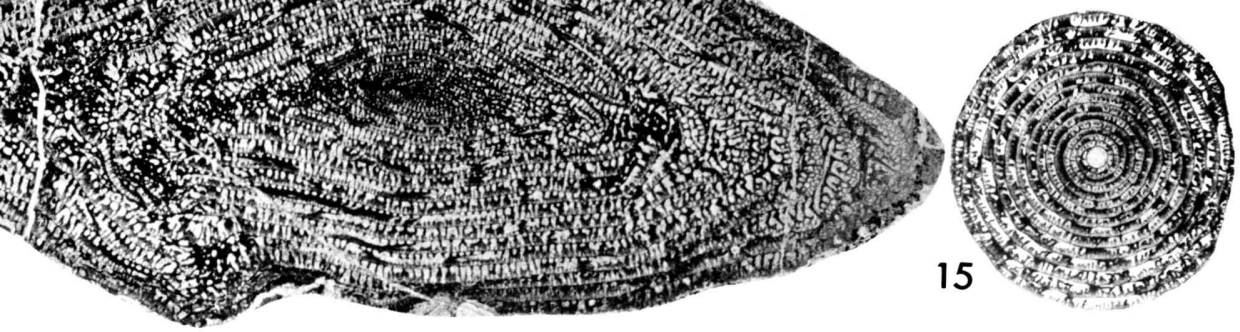

T. OzAWA: Evolution of Lepidolina multiseptata 

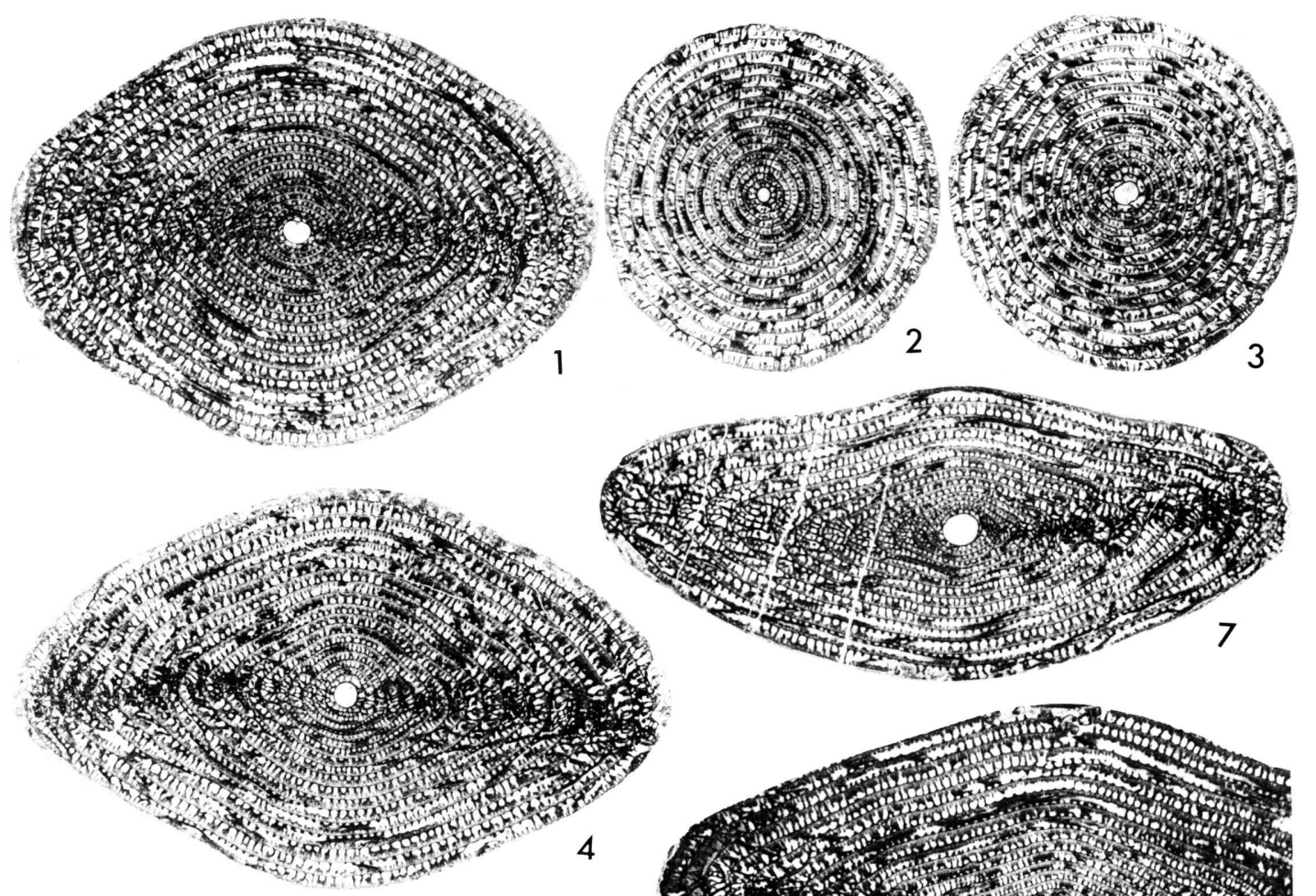

7.18.

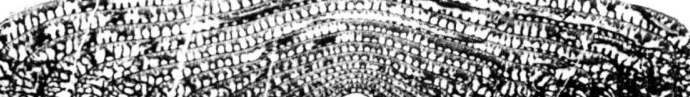

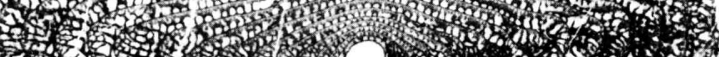
(1) (5)

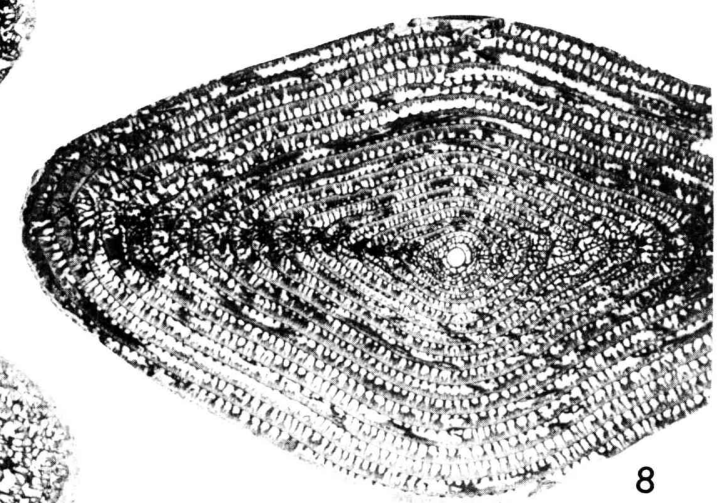
(3)
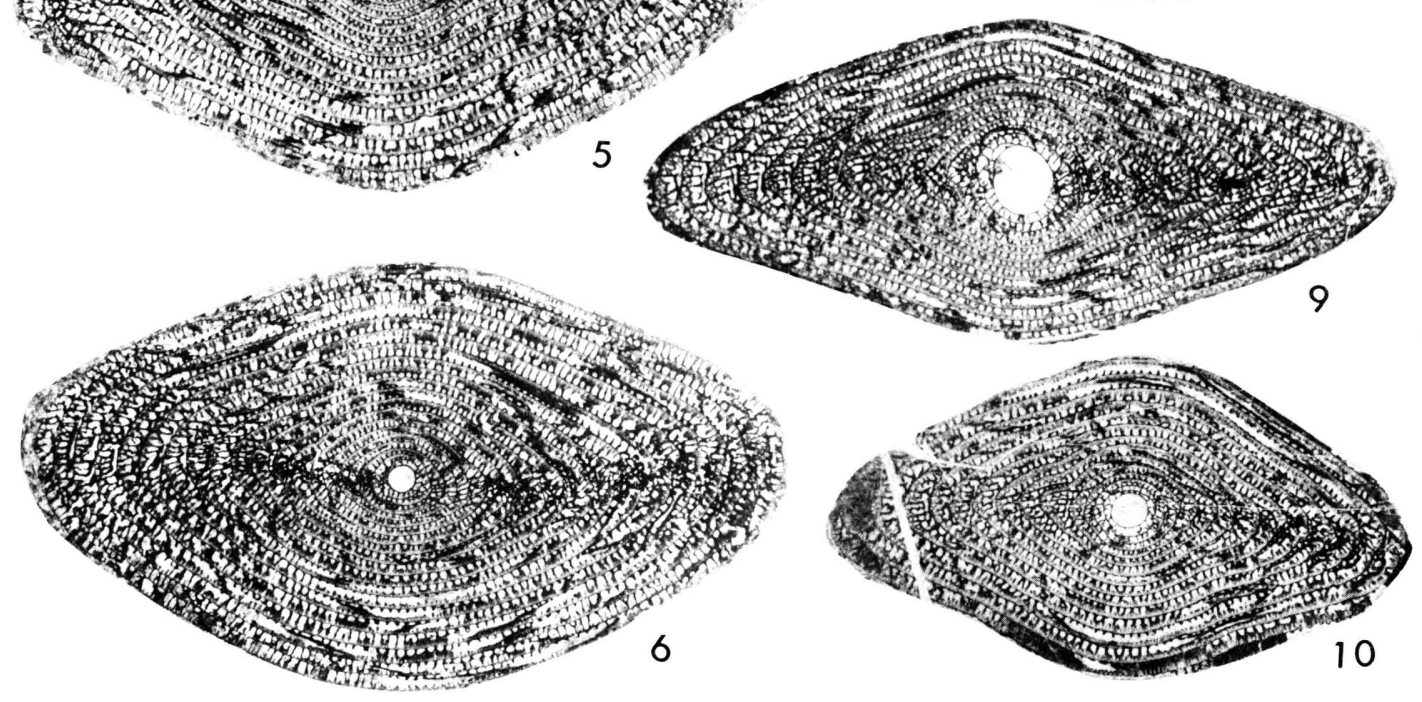

T. Ozawa: Evolution of Lepidolina multiseptata 
6-8, text-fig. 16.

1935. Neoschwagerina megaspherica DeJRat; Gubler [non DePrat, 1913], p. 114-116, pl. 7, fig. 3; pl. 6, fig. 4.

1935. Neoschwagerina elongata GUBLER, p. 108-111, pl. 8, figs. 1, 2, 5, 12, textfig. 46.

1935. Neoschwagerina douvillei OzAWA; GUBER [non OzAwa, 1922], p. 111-113, pl. 7, figs. 7, 8, 10 ?; pl. 8, fig. 6, 10 ?.

1942. Yabeina yasubaensis TORIYAMA, p. 246, 247, pl. 25, figs. 8-13.

1948. Lepidolina multiseptata, TномРson, pl. 20, figs. 5, 6; pl. 22, figs. 1-5.

1951. Yabeina multiseptata, HoRNIBrook, p. 320, pl. 50, figs. 1, 2.

1951. Yabeina sp.; HORNIBROOK, p. 320, pl. 50, fig. 3.

1954. Lepidolina multiseptata SkINNER and WILDE, p. 449, 450, pl. 52, figs. 1-5.

1954. Yabeina gubleri KANMERA, p. 19-21, pl. 4.

1954. Yabeina yasubaensis, KANMERA, p. 18, 19, pl. 2, figs. 10-13; pl. 5, figs. 14-19.

? 1954. Yabeina columbiana (DAwson) ; KANMERA, p. 16-18, pl. 3, figs. 1-7.

1958. Lepidolina multiseptata, SAURIN, p. 239, 230, pl. 1, fig. 13; pl. 2, figs. 9, 10.

1958. Yabeina khmeriana SAURIN, p. 226, 227, pl. 1, figs. 6-11.

1958. Yabeina johannis SAURIN, p. 228, 229, pl. 2, figs. 1-8.

1958. Yabeina yasubaensis, NoGAMI, p. 102, 103, pl. 1, fig. 8 .

1958. Yabeina columbiana, NogAMI, p. 101, 102, pl. 1, figs. 9, 10.

1959. Lepidolina multiseptata, LE-THI-VIEN, p. 117, 118.

1959. Lepidolina multiseptata var. sphaerica LE-THI-VIEN, p. 118, pl. 2 , fig. 1.

1960. Yabeina gubleri, CHISAKA, p. 250, 251, pl. 6, figs. 1-4; pl. 7, figs. 1-6; pl. 8, figs. 1-5.

1960. Yabeina proboscis CHeN; ChISAKA, p. 252, 253, pl. 9, fig. 2.

par. 1962. Yabeina shiraiwensis OzAWA; IsHII and NogAmI, p. 63-66, pl. 2.

1964. Yabeina multiseptata multiseptata, IsHII and NoGAMI, p. 17-20, pl. 3, figs. 1-3, pl. 4, figs. 1-3, pl. 5, figs. 1-4.

1964. Yabeina multiseptata gigantea, IsHII and NoGAMI, p. 20-22, pl. 6, figs. 1-4.

? 1964. Yabeina minuta THOMPSON and WheELER; IshiI and NogAMI, p. 22, pl. 4, figs. 4-7 [non THOMPSON and WHEELER, 1942].

par. 1964. Yabeina multiseptata shiraiwensis, IsHII and NoGami, pl. 5, fig. 2.

1964. Yabeina elongata, IsHII and NoGAMI, p. 23, pl. 7, figs. 1-3.

1964. Lepidolina multiseptata, Thompson, fig. 283; fig. 292-2a, -2b; fig. 327-2.

1964. Lepidolina elongata, ThOMPSON, fig. 275-5; fig. 276-4.

1966. Yabeina multiseptata shiraiwensis, SADA and YoKoYAMA, p. 307-311, pl. 33, figs. 1-3.

1966. Yabeina multiseptata multiseptata, SADA and YokoYAMA, p. 307-311, pl. 33, figs. 1-3.

1966. Yabeina multiseptata multiseptata, SADA and YokочамA, p. 304-307, pl. 33 , figs. $4,5,7,8$.

\section{Explanation of Plate 25}

All figures $\times 6.6$

Figs. 1-10. Lepidolina multiseptata (DEPRAT) transient multiseptata DePRAT

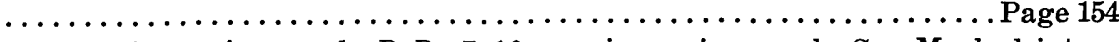

1-6, specimens in sample $P s B .7-10$, specimens in sample $S a$. Marked intrapopulational variation occurs in shell form and the prolocular diameter. 1, 4-6, $7-10$, axial sections of megalospheric shell. 2, 3, sagittal sections of megalospheric shell. 
1966. Yabeina minuta, SAdA and YokoYama, p. 309-311, pl. 34, figs. 3, 4.

1966. Yabeina elongata, SAdA and YokoYAMA, p. 311, 312, pl. 34, figs. 1, 5.

1970. Lepidolina multiseptata multiseptata, OzAwA, pl. 1, fig. 4; pl. 8; pl. 9, figs. 2-5.

1971. Lepidolina multiseptata gigantea, YAMAGIWA, IWAHASHI and HABUCHI, p. 55, pl. 1, fig. 1 .

1971. Lepidolina multiseptata shiraiwensis, YAMAGIWA, IWAHASHI and HABUCHI, p. 56, pl. 1, fig. 2.

1971. Yabeina sp.; Yamagiwa, Iwahashi and Habuchi, pl. 1, fig. 3.

1972. Lepidolina multiseptata gigantea, YAMAGIWA and SAKA, p. 265, pl. 31, fig. 1.

1972. Lepidolina multiseptata multiseptata, YAMAGIWA and SAKA, p. 266, pl. 31, fig. 2.

1972. Yabeina columbiana, YamagiwA and SAKA, p. 268, pl. 31, fig. 4.

non 1961. Yabeina sp. cf. Y. multiseptata, MorikawA and SuzukI, p. 66, pl. 9, fig. 4; pl. 14, fig. 10.

Characters.-Megalospheric shell large, inflated to elongate fusiform, with a straight to slightly shifting axis of coiling. Mature shells of 15 or more volutions about 6 to $15 \mathrm{~mm}$ in length and 4.5 to $7.5 \mathrm{~mm}$ in width. Form ratio varies from 1.4 to 2.8 , mostly from 1.6 to 2.3. Proloculus large. Its outside diameter varies from 220 to 1000 microns, mostly 380 to 580 microns. Spirotheca thin, consisting of a tectum and a very thin keriothecal layer. Its thickness about 5 to 10 microns

\section{Explanation of Plate 26}

All figures $\times 13.2$, unless otherwise stated

Figs, 1, 4. Lepidolina multiseptata (DEPRAT) transient asiatica IsHII

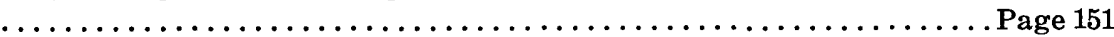
1, enlarged figure of a part of the same specimen as Fig. 1 of Plate 22, showing proloculus, juvenile volutions and incipient secondary transverse septula. The secondary transverse septula is not yet developed in inner volutions. 4 , enlarged figure of a part of a sagittal section, showing septa and axial septula (specimen in sample $J p$ ).

Figs. 2, 5. Lepidolina multiseptata (DEPRAT) transient shiraiwensis OzAWA

......................................... Page 152

2, enlarged figure of a part of the same specimen as Fig. 3 of Plate 23, showing juvenile volutions and, primary and secondary transverse septula. 5, enlarged figure of a part of a sagittal section, showing septa and axial septula (specimen in sample $H a I$ ).

Figs. 3, 6-11. Lepidolina multiseptata (DEPRAT) transient multiseptata

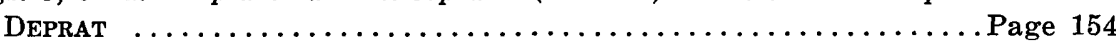
3, enlarged figure of a part of the same specimen as Fig. 4 of Plate 25, showing juvenile volutions, primary and secondary transverse septula. The secondary septula are well developed. $\times 20$. 8, enlarged figure of a part of the same specimen as Fig. 3 of Plate 25, showing septa and well developed axial septula. $\times 20$. 6, 7, tangential sections showing the chamberlet formed by the intersection of the primary and secondary transverse septula, and axial septula. 6, specimen in sample $S a$. 7, specimen in sample $P s B$. 9, tangential section cutting the spirotheca and septula, showing numerous pores, alveoli. The same specimen as Fig. 6. $\times 66$. 10, enlarged figure of a part of a sagittal section, showing proloculus. The proloculus apertures are opening. Specimen in sample $P b C$. 11, enlarged figure of a part of an axial section of microspheric shell, showing juvenile volutions and proloculus. 


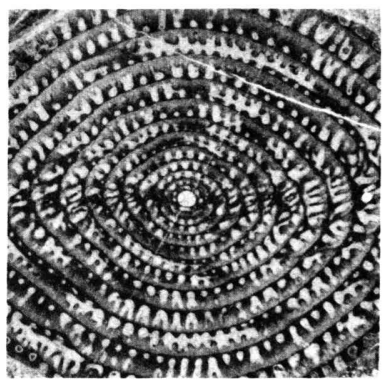

1

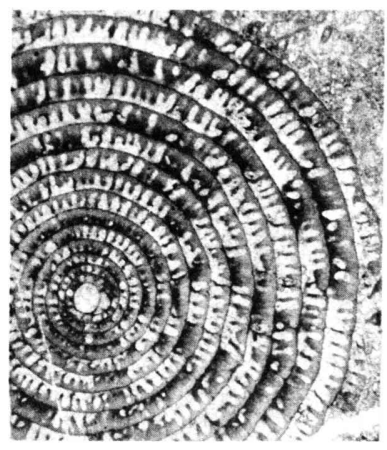

4

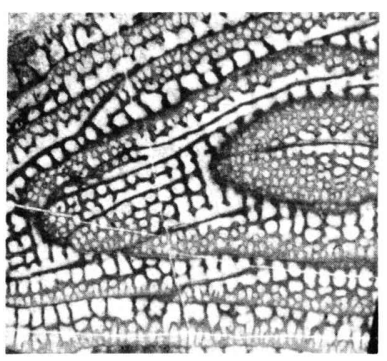

6

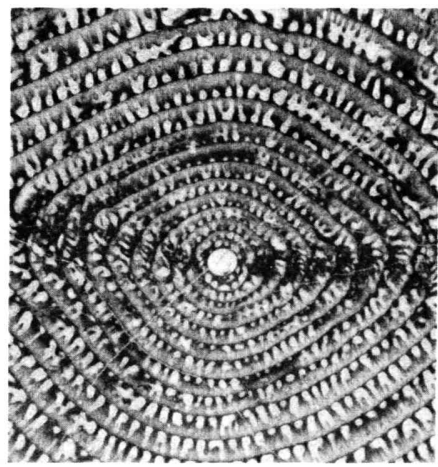

2

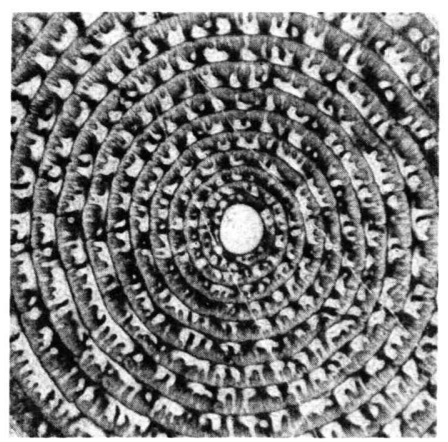

5

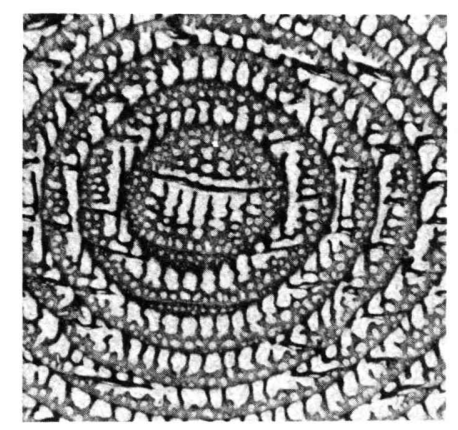

7

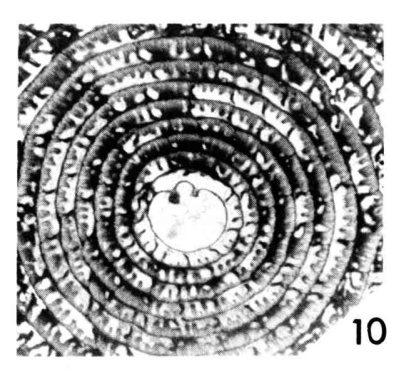

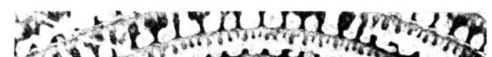
114...... riforition

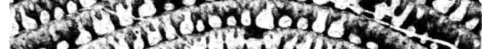
1000 .

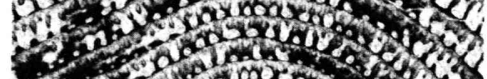
15,120 Hor. 2. 25000.

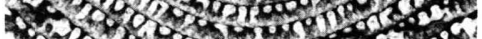
40 m 6. 10 opmor

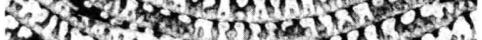
S.T. 3

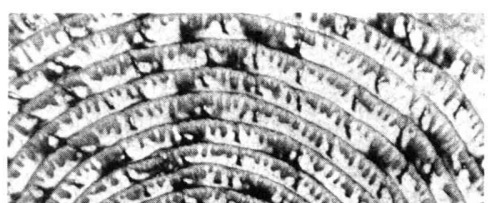

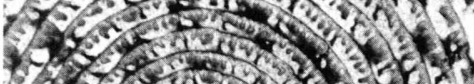

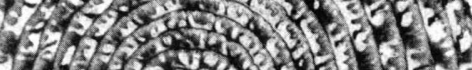
960 - 1 . (1) 0 \% (2) 34565 $120 \% 5$

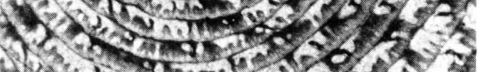

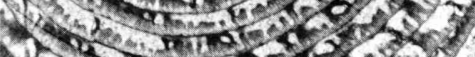
20 - 0125

8

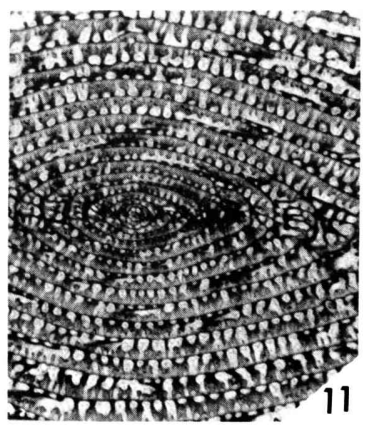

T. OzAwa: Evolution of Lepidolina multiseptata 
in outer volutions of mature shells. Septula thin. Its lower half consolidated with material which is related to the parachomata. 5 to 11 , mostly 7 or 9 axial septula occur at tenth volution. Secondary transverse septula first in the third volution. Microspheric shells very large, elongate fusiform to cylindrical, with an inflated central part, a nearly straight to shifting axis of coiling, and 20 or more volutions. Mature shells about 12 to $21 \mathrm{~mm}$ in length and 4.5 to $8.5 \mathrm{~mm}$ in width, giving form ratios of 3 to 4.5. Inner two volutions lenticular in form, with a small proloculus and a short axis of coiling.

Distribution.-Lepidolina multiseptata transient multiseptata occurs in the lower Upper Permian of the Japanese Islands, Sikhote Alin in the Far East of U.S.S.R., South China. Southeast Asia and New Zealand. It is known to occur in the uppermost part of the lower Upper Permian of the Japanese Islands and Sikhote Alin, forming the latest verbeekinoid fauna.

Paleoecological environment.-With the exception of Sisophon limestone, Cambodia and Maokou limestone, South China, Lepidolina multiseptata transient multiseptata occurs in small or extremely small limestone lenses of about $10 \mathrm{~m}$ to $0.2 \mathrm{~m}$ thick, intercalated in black shale and sandstone. Limestones are calcareous algaeforaminifera biomicrite with a lime-mud matrix. Sometimes it occurs in the limemud matrix of the conglomeratic limestone. Species of Sumatrina are not associated with it. Species of Chusenella, Metadoliolina, Codonofusiella, Dunbarula, Kahlerina, Pachyphloia, Wangenella, etc., are commonly associated with Lepidolina multiseptata transient multiseptata, forming an Upper Permian foraminiferal community.

Remarks.- The specimens of samples $Y m, N z, Y b, P t, P b D l, P b D u, P s A, P s B$, $P l, F u, S a$ and $K m$ belong to Lepidolina multiseptata transient multiseptata.

\section{Concluding Remarks}

As is well demonstrated by many lines of evidence, gradual morphologic change in phyletic lineages is not a rare phenomenon in the evolutionary history of the invertebrate as well as vertebrate animals. HILGENDORF in the seventh decade of the eighteenth century, Rowe (1899), TRUEMAN (1922), MAKIYAMA (1924) and many other invertebrate paleontologists had already noticed the gradual morphologic shift of an lineage in time. In such a mode of evolution, size increase accompanied by increased structural complexity or modification is commonly recognized. SIMPSON (1944), ROMER (1949) and NEWELL (1949) paid special attention to one-way evolutionary trend in fossil vertebrates and invertebrates, and interpreted the trends in the light of modern biology. They gave an account of this trend in fossil animals from the standpoint of orthoselection, instead of teleogical thought of "orthogenesis". Since the new systematics have been introduced into paleontology during the sixth decade of this century, evolutionary paleontology has been more and more focused on the fossil populations rather than the individuals. Thus, classical works by Rowe, TRUEMAN and several others have been restudied in the light of modern paleontology. Many subsequent studies of Cretaceous Micraster (e. g. NICHOLS, 1959a, 1959b, ERNST, 1970, etc.) and Jurassic Gryphaea series (e. $g$. JOYSEY, 1959, HALla M, 1968, VAN VALEN, 1968) as well as several outstanding results in fossil invertebrates and vertebrates (e.g., HAYAMr, 1973, etc.) have realized evolutionary development in a successive lineage as the gradual shift of the population with time. They have explained the evolutionary process 
as the results of natural selection. The evolution of Lepidolina in an extensive geographic region during the Permian times may be visualized as the phyletic size increase and shape transformation accompanied by gradually increased structural complexity. This phenomenon may be explicable by current concept of basic mechanism of evolution; random mutation, recombination and accumulation of numerous very small genetic changes in populations through environmental selection. I believe that most of animal species arise rapidly by geographic speciation and not by "phyletic speciation". The present study is not inconsistent with ELDREDGE and GouLD's model (1972) of allopatric speciation which they called punctuated equilibria, because this paper deals only with the morphologic change of a species probably formed by geographic speciation.

Acknowledgements.-I would like to express my sincere gratitude to Professor Tatsuro Matsumoto of the Kyushu University, Professor Ryuzo ToriYaMa of the Fukuoka University and Associated Professor Kametoshi Kanmera of the Kyushu University for their invaluable advice and encouragement throughout the present work. Associated Professor K. KANMERA kindly read the first draft of this paper.

I am very grateful to Dr. Raymond C. Douglass of the United States Geological Survey, Washington, D.C. and Dr. Itaru HAYAMI of the University of Tokyo Museum for their kind advice, fruitful discussion and critical reading of the draft. I am indebted to Professor Tetsuro HaNaI of the University of Tokyo for his invaluable suggestion and discussion about taxonomic problems of fossil animals.

Deep appreciation is also due to Dr. Ken-ichi IsHII (Osaka City University), Dr. Yasuo Nogami (Kyoto University), Dr. Masafumi Murata (Tohoku University), Dr. Takeshi IshiBashi (Kyushu University) and Dr. N. de B. HoRnIBRooK (New Zealand Geological Survey) who have kindly supplied their collections of Lepidolina multiseptata for the present study. Dr. K. IsHII furthermore gave me his stratigraphic data of the limestone of West Cambodia. Dr. Masamichi OTA of Akiyoshi-dai Science Museum kindly collaborated in collecting specimens from the Akiyoshi province, Japan. Miss Mutsuko HAYASHIDA kindly assisted me in preparing the typescript. Financial aid for this study was granted by the Ministry of Education of Japan and the Matsunaga Science Foundation, Tokyo.

\section{References Cited}

ADAMS, G. C. (1957): A study of the morphology and variation of some Upper Lias foraminifera. Micropaleont., 3, 205-226.

ARNold, Z. M. (1955): Life history and cytology of the foraminiferan Allogromia laticollaris. Univ. Calif. Pub. Zoology., 61, 167-252, pls. 27-35.

BANDY, O. L. (1964) : General correlation of foraminiferal structure with environment. In J. IMBRIE and N. NEWELL (eds.): Approaches to paleoecology, John Wiley and Sons, New York, 75-90.

BAther, F. A. (1927): Biological classification: past and future. Quart. Jour. Geol. Soc., 83, 52-104.

BRADSHAw, J. S. (1957) : Laboratory studies on the rate of growth of the foraminifer "Streblus beccari (LinNè) var. tepida (CUShMaN)". J. Paleont., 31, 1138-1147.

Chen, S. (1956): Fusulinidae of South China, Part 2. Palaeont. Sinica, N. S. [B], 1-71, pls. 1-14.

Chisaka, T. (1960): On some Permian Fusulinids from the Takagami Conglomerate, Chosi Peninsula, Chiba Prefecture, Japan. Jour. Coll. Arts and Sci. Chiba Univ., 3, 235-254, pls. 1-9. 
(1960): Verbeekininae, Neoschwagerininae and Sumatrininae from Japan. "Fossils", Palaeont. Soc. Japan, (1) 17-28. (in Japanese)

Chor, D. R. (1970): On some Permian fusulinids from Iwaizaki, N. E. Japan. Jour. Fac. Sci., Hokkaido Univ., Ser. 4, [Geol. and Mineral.], 14, 313-325, pls. 5-8. (1970) : Permian fusulinids from Imo, Southern Kitakami Mountains, N. E. Japan. Ibid., 14, 327-354, pl. 9-15.

Colani, M. (1924): Nouvelle contribution a l'étude des Fusulinidés de l'ExtrêmeOrient. Indochine Service Géol., Mém. 11, 1-191, pls. 1-29.

Cutbill, J. L. and Forbes, C. L. (1967): Graphical aids from the description and analysis of variation in fusuline foraminifera. Palaeont., 10, 323-337.

Deprat, J. (1912) : Étude des Fusulinidés de Chine et d'Indochine et classification des calcaires à fusulinés. Mem. Surv. Geol. l'Indochine, 1, 1-76, pls. 1-9.

(1913): Étude des Fusulinidés de Chine at d'Indochine et classification des calcaires à fusulinés (II ${ }^{\circ}$ Mémoire). Les Fusulinidés des calcaire carbonifériens et permiens du Tonkin, dú Laos et du Nord-Annam. Ditto, 2, 1-74,, pls. 1-10.

(1914) : Étude des Fusulinidés du Japon, du Chine et d'Indochine et classification des calcaires à fusulines (III ${ }^{e}$ Mémoire). Etude comparative des Fusulinidés d'Akasaka (Japon) et des fusulinidés de Chine et d'Indochine. Ditto, 3, 1-45, pls. $1-8$.

Douglass, R. C. (1970): Morphologic studies of fusulinids from the Lower Permian of West Pakistan. U. S. Geol. Surv. Prof. pap., 643-G-G11, pls. 1-7.

Dunbar, C. O. (1940): Fusulinidae. In J. A. Cushman (ed.): Foraminifera their classification and economic use. Harvard Univ. Press, 132-156, pls. 10-12, 44.

(1963) : Trends of evolution in American Fusulines. In C. H. R. von Koenigswald, J. D. Emeis, W. L. Buning and C. W. WAgNer (eds.) : Evolutionary trends in foraminifera. Elsevier, 26-44.

and Henbest, L. G. (1942): Pennsylvanian Fusulinidae of Illinois. Illinois State Geol. Surv. Bull., 67, 1-218, 23 pls.

and Skinner, J. W. and KIng, R. E. (1936): Dimorphism in Permian Fusulines. Univ. Texas Bull., 3501, 173-190, pls. 1-3.

and Skinner, J. W. (1937): Fusulinidae of Texas. The geology of Texas, 3, Univ. Texas Bull. 3701, 517-825, pls. 42-81.

ELDREDGe, N. and Gould, S. J. (1972) : Punctuated equilibria: an alternative to phyletic gradualism. In Models in Paleobiology, J. M. ScHOPF (ed.). Freeman, Cooper \& Co., 82-115.

ERNST, G. (1970): Zur Stammengeshichte und Stratigraphishen Bedeutung der Echiniden-Gattung Micraster in der nordwestdeutchen oberkreide. Mitt. Geol. -Palaont. Inst. Univ. Hamburg, 39, 117-135.

Fisher, R. A., Corbet, A. S. and Williams, C. B. (1943): The relation between the number of species and the number of individuals in a random samples of an animal population. Jour. Animal Ecol., 12, 42-58.

Fontaine, H. (1967) : Quelques Madreporaires permiens du Viet-Num et du Cambodia. Archives Geol. du Viet Num, 51-58, pls. 1-3.

GoBbETT, D. J. (1967) : Palaeozoogeography of the Verbeekinidae (Permian foraminifera). In C. G. ADAMS and D. V. AGER (eds.) : Aspects of Tethyan Biogeography. Systematic Assoc. Publ., (7), 77-91.

Gordon, W. A. (1966) : Variation and its significance in classification of some English Middle to Upper Jurassic nodosariid foraminifera. Micropaleont., 12, 325-333, pls. 1-2.

Gubler, J. (1935) : Les Fusulinidés du Permien de l'Indochine, leur structure et leur classification. Soc. Geol. France, Mem., [N. S.], 11, 1-173, pls. 1-8.

HallaM, A. (1968): Morphology, Palaeoecology and Evolution of the genus Gryphaea in the British Lias. Phil. Trans. Roy. Soc. Lond., [B], 254, 91-128, pls. 10-12.

Hanzawa, S. (1954): Regional geology of Japan; Tohoku Province, 1-344. Asakura 
Shoten Press, Tokyo. (in Japanese)

and MURATA, M. (1963) : The paleontological and stratigraphical considerations on the Neoschwagerininae and Verbeekininae with the description of some fusulinid foraminifera from the Kitakame Massif, Japan. Sci. Rep. Tohoku Univ., [Geol.], 35, 1-31, pls. 1-20.

HASegaWA, Y. (1965): "Lepidolina" from the Otani Conglomerate, Central Japan. "Eath Science" (Chikyu Kagaku), (76), 25-33, pls. 1-3.

(1966): On the proloculus size of Lepidolina shiraiwensis (Ozawa). Sci. Rep. Geol. and Mineral., Niigata Univ., 21-29, pl. 1. (in Japanese with English abstract)

HayamI, I. (1973): Discontinuous variation of an evolutionary species, Cryptopecten vesiculosus, from Japan. J. Paleont. 47, 401-420, pls. 1-2.

HAYASAKA, I. (1924): On the fauna of the anthracolithic limestone of Omi-mura in the western part of Echigo. Sci. Rep. Tohoku Imp. Univ., 8, 1-83, pls. 1-7.

Henningsmoen, G. (1964) : Zig-zag evolution. Norsk Geol. Tidsakrift, 44, 341-352.

HorNibrook, N. de B. (1951): Permian fusulinid foraminifera from the North Auckland Peninsula, New Zealand. Trans. Roy. Soc. New Zealand, 79, 319-321, pl. 50.

HotTinger, L. (1963): Les Alveolines paleogenes exemple d'um genre polyphyletique. In G. H. R. Konigswald, J. D. Emeis, W. L. Buning and C. W. WagneR (eds.) Evolutionary trends in foraminifera. Elsevier, 298-314.

Huziмото, H. (1936): Stratigraphical and palaeontological studies of the Titibu System of the Kwanto-mountainland. Part 2, Palaeont., Sci. Rep. Tokyo Bunrika Daigaku, [C], 32-125, pls. 1-26.

Igo, H. (1960): Yabeina from the Omi limestone, Niigata Prefecture, Central Japan. Sci. Rep. Tohoku Univ., 2, [Geol.], Spec. vol. 4, 335-343, pl. 36.

(1964) : Permian fossils from Northern Pahang, Malaya. Jap. Jour. Geol. Geogr., 35, 57-71, pl. 2.

IMBRIE, J. (1957) : The species problem with fossil animals. In E. MaYr (ed.): The species problem. Amer. Assoc. Advanc. Sci., Pub. No. 50, 125-152.

IsHII, K. (1966) : On some fusulinids and other foraminifera from the Permian of Pahang, Malaya. Jour. Geosci., Osaka City Univ., 9, Art. 4-V, 131-136, pls. 5-6. (1966): Permian of the western part of Cambodia-On the stratigraphy of Sisophon and Battambang limestone in Cambodia. "Fossils" (Kaseki), Palaeont. Soc. Japan, (12), 29-39. (in Japanese)

- Kato, M. and Nakamura, K. (1969): Permian limestone of West Cambodia. Litho- and biofacies. In T. MATSUMoto (ed.): Litho- and bio-facies of carbonate sedimentary rocks, a symposium. Palaeont. Soc. Jap. Spec. Pap. No. 14, 41-55. and Nogami, Y. (1962): On Yabeina shiraiwensis Ozawa Yabeina yasubaensis ToriYama. Jour. Geosci. Osaka City Univ., 6, 59-67, pls. 1-2.

and - (1964): Contribution to the geology and paleontology of Cambodia. Part 1. Permian Fusulinids. Ibid., 8, 9-37, pls. 1-8.

and Shimizu, D. (1968): Palaeofusulina-Colaniella fauna of the Permian Maizuru Group, Japan. "Fossils" (Kaseki), (15), 26-30. (in Japanese)

JOYSEY, K. A. (1959): The evolution of the Liassic oysters Ostrea-Gryphaea. Biol. Rev., 34, 297-332.

KAEsler, R. L. and WATERS, J. A. (1972): Proloculus size and natural selection in Triticites ventricosus (Fusulinacea). J. Paleont., 46, 360-363.

KANMERA, K. (1953): The Kuma formation with special reference to the Upper Permian in Japan. Jour. Geol. Soc. Japan, 59, 449-468. (in Japanese with English abstract)

(1954): Fusulinids from the Upper. Permian Kuma formation, Southern Kyushu, Japan, with special reference to the Fusulinid zone in the Upper Permian of Japan. Mem. Fac. Sci. Kyushu Univ., [D], 4, 1-38, pls. 1-6.

(1957) : Revised classification of Cancellina and Neoschwagerina, and evolution 
of Sumatrininae and Neoschwagerininae. Ibid., 6, 47-64, pl. 19-20.

(1963) : Fusulines of the Middle Permian Kozaki formation of southern Kyushu. Ibid., 14, 79-141, pls. 11-19.

and Nakazawa, K. (1973): Permian-Triassic relationship and faunal changes in the eastern Tethys. In LOGAN and HILLs (eds.) : Permian and Triassic Systems and their mutual boundary. Canad. Soc. Petr. Geol., Mem. no. 2, 100-119.

Kawano, M. (1961): Stratigraphical and paleontological studies of the Paleozoic formations in the western part of the Chugoku Massif. Bull. Fac. Educ., Yamaguchi Univ., Mathematics and Sci., 11, Spec. Number, 1-133, pls. 1-15.

LANGE, E. (1925) : Eine mittelpermische fauna von Guguk Bulat (Padanger Oberland, Sumatra). Geol-mijnb. Genootsch. Nederland en kolonien Verh., Geol. Ser., 7, 157-239, pls. 1-5.

Lee, J. J., Freudenthal, H. D., Muller, W. A., Kossy, V., Pierce, S. and Grossman, R. (1963) : Growth and physiology of foraminifera in the laboratory: Part 3Initial studies of Rosarina floridana (CushmaN). Micropaleont., 9, 449-446, pls. $1-3$.

LeE, J. S. (1933) : Taxonomic criteria of Fusulinidae with notes on seven new Permian genera. Mem. National Research Inst. Geol., (14), 1-21, pls. 1-5.

LEwIS, K. B. and Jenkins, C. (1969): Geographic variation of Nonionellina flemingi. Micropaleont., 15, 1-12, pl. 1.

Leoblich, A. R. Jr. and TAPPAN, H. (1964) : Protista. C900 pp. In R. C. Moor (ed.) : Treatise on Invertebrate Paleontology, Part C, Geol. Soc. Amer. and Univ. Kansas Press.

MABUCHI, S. (1935) : The Iwaizaki limestone and its stratigraphic position. Bull. Saito Ho-onkai, 1-18.

MakiYama, J. (1924): The evolution of Umbonium. Jap. Jour. Geol. Geogr., 3, 119130 , pl. 20.

MaXwell, W. G. H. (1968): Atlas of the Great Barrier Reef. 258 pp. Elsevier, Amsterdam.

MAYER, E. (1963): Animal species and evolution. 797 pp. Harvard Univ. Press.

(1969): Principles of Systematic Zoology. 428 pp. McGraw-Hill.
, LINSLEY, E. G. and UsINGER, R. L. (1953): Methods and principles of systematic zoology. $336 \mathrm{pp}$. McGraw-Hill.

MikLukho-MakLAY, A. D. (1958) : Systematics of highly advanced fusulinids (Superfamily Verbeekinaceae). Bull. Lenigrad Univ., Number 12, Ser. Geol. Geogr., 2, $5-14$.

Minato, M. and Honjo, S. (1959): The axial septula of some Japanese Neoschwagerininae with special remarks of the phylogeny of the subfamily Neoschwagerininae DUNBAR and CONDRA, 1928. Jour. Fac. Sci., Hokkaido Univ., 4, (10), 305-336, pls. $1-6$.

MORIKAWA, R. (1956) : Fusulinids from Onagata, Kamiyoshida-mura, northern part of Kwanto mountainland, Central Japan. Sci. Rep. Saitama Univ., 2, 250-260, pls. 32-34.

and SuzukI, Y. (1961) : Fusulinids from the Akasaka limestone (Part 2). Ibid., [B], 43-70, pls. 4-22.

et al. (1958) : Stratigraphy and biostratigraphy of the "Iwaizaki limestone" in the southern Kitakami mountainland. Jubilee Publ. Prof. H. Fujimoto, 81-90, pl. 6. (in Japanese with English abstract)

MYERS, E. H. (1938) : The present state of our knowledge concerning the life cycle of the foraminifera. Proc. Nat. Acad. Sci., Washington, 24, 10-17.

(1940): Observation on the origin and fate of flagellated gamates in multiple tests of Discorbis (Foraminifera). Jour. Marine Biol. Assoc. United Kingdom, N. S., 24, 201-226, pls. 1-3.

Nakazawa, K. and Newell, N. D. (1968) : Permian bivalves of Japan. Mem. Fac. Sci. 
Kyoto Univ., Ser. Geol. and Mineral., 35, 1-108, pls. 1-11. and SHIKI, T. (1958): Paleozoic and Mesozoic formations in the vicinity of Kawahigashi, Oe-cho, Kyoto Prefecture, Japan. A study on the stratigraphy and geological structure of the "Maizuru Zone", Part 5. Jour. Geol. Soc. Jap., 64, 57-67. (in Japanese with English abstract)

- et al. (Working group on the Permian-Triassic Systems) (1975): Stratigraphy near the Permian-Triassic Boundary in Japan and its correlation. Jour. Geol. Soc. Japan, 81, (3), 165-184. (in Japanese with English abstract)

Newell, N. D. (1949) : Phyletic size increase, an important trend illustrated by fossil invertebrates. Evolution, 3, 103-124.

and RIGBY, J. K. (1957): Geological studies on the Great Bahama Bank. In R. L. LE BLANC and J. G. BREEDING (eds.) : Regional aspects of carbonate deposition. Soc. Econ. Paleont. Mineral., Spec. Publ. No. 5, Tulsa, Oklahoma, 13-72.

Nicol, D. (1944): New west American species of the foraminiferal genus Elphidium. J. Paleont., 18, 172-185, pl. 29.

Nichols, D. (1959a): Changes in the Chalk heart-urchin Micraster interpreted in relation to living forms. Phil. Trans. Roy Soc., B, 242, 347-437.

$(1959 \mathrm{~b})$ : Mode of life and taxonomy in irregular seaurchins. In A. J. Cain (ed.): Function and taxonomic importance. Syst. Assoc. Lond., Publ. No. 3, 61-80.

Nogami, Y. (1958): Fusulinids from the Maizuru Zone, Southwest Japan, Part 1. Ozawainellinae, Schubertellinae and Neoschwagerininae. Mem. Coll. Sci. Univ. Kyoto, [B], 25, 97-114, pls. 1-2.

(1961) : Permische Fusuliniden aus dem Atetsu-Plateau sudwestjapans. Teil 2, Verbeekininae, Neoschwagerininae u. a., Ibid., 28, 159-228, pls. 1-7.

(1962) : Jungpalaozikum in Atetsu-Plateau sudwestjapans. Ibid., 29, 161-176.

Ota, N., Sugrmura, A. and OtA, M. (1969) : Reef deposits in the Millerella zone of the Akiyoshi limestone Group. In T. MATSUmoto (ed.): Litho- and bio-facies of carbonate sedimentary rocks. A symposium. Palaeont. Soc. Jap., Spec. Pap. no. $14,1-12$, pls. $1-3$.

OzawA, T. (1970): Notes on the phylogeny and classification of the Superfamily Verbeekinoidea. Mem. Fac. Sci. Kyushu Univ., [D], 20, 17-58, pls. 1-9. (1970): Variation and relative growth of Colania douvillei from the Rat Buri Limestone. Geol. Palaeont. Southeast Asia, 8, 19-42, pls. 3-6.

Ozawa, Y. (1922): Preliminary notes on the classification of the Family Fusulinidae. Jour. Geol. Soc. Japan, 29, 352-365. (in Japanese)

(1923): Stratigraphical study on the so-called Upper Chichibu Palaeozoic system including the Akiyoshi limestone. Jour. Geol. Soc. Japan, 30, 222-243. (in Japanese)

(1925a): On the classification of Fusulinidae. Jour. Coll. Sci. Imp. Univ. Tokyo, 45, Art. 4, 1-26, pls. 1-4.

(1925b) : Paleontological and stratigraphical studies on the Permo-Carboniferous limestone of Nagato. Part 2, Paleontology. Ibid., 45, Art, 6, 1-90, pls. 1-14.

ReICHEL, M. (1964) : Alveolinidae. In R. C. MOORE (ed.): Treatise on Invertebrate paleontology, Part C, Protista 2, Geol. Soc. Amer. and Kansas Univ. Press, C503510a.

RODGERS, J. (1957): The distribution of marine carbonate sediments: A review. In R. J. Le BLANC and J. C. BREeding (eds.) : Regional aspects of Carbonate deposition. Soc. Eco. Paleont. and Mineral., Spec. Publ. no. 5, Tulsa, Oklahoma, 2-14.

Romer, A. S. (1949): Time series and trends in animal evolution. In G. L. JEPSEN, G. C. Simpson and E. MAYR (eds.): Genetics, Paleontology and evolution, Princeton Univ. Press, 103-120.

Ross, C. A. (1962): The evolution and dispersal of the Permian Fusulinid genera Pseudoschwagerina and Paraschwagerina. Evolution, 16, 306-315. 
RowE, A. W. (1899) : An analysis of the genus Micraster, as determined by rigid zonal collecting from the Zone of Rhynchonella cuvieri to that of Micraster coranguinum. Quat. Jour. Geol. Soc. Lond., LV, 494-547, pls. 35-39.

RuzhentSev, V. E. and SARYcheva, T. G. (eds.) (1965) : The development and change of marine organisms at the Palaeozoic-Mesozoic boundary. Transact. Palaeont., Acad. Sci. U.S.S.R., 108, 1-312, pls. 1-5. (in Russian)

SADA, K. (1960): On the Upper Permian fusulinid fauna in the Atetsu limestone plateau, Okayama Prefecture. Jour. Geol. Soc. Japan, 66, 410-425. (in Japanese with English abstract)

(1965): Carboniferous and Permian stratigraphy of the Atetsu limestone in West Japan. Jour. Sci. Hiroshima Univ., [C], 5, 21-80, pl. 1.

and Yokoyama, T. (1966): Upper Permian Fusulinids from the Taishaku limestone in West Japan. Trans. Proc. Palaeont. Soc. Japan, N. S., 63, 303-315, pls. 33-34.

SANDerson, G. A. and Verville, G. J. (1970): Morphologic variability of the genus Schwagerina in the lower Permian Wreford Limestone of Kansas. Palaeont., $13,175-183$, pls. $35-36$.

Saurin, E. (1958): Fusulinides du Phnom Cau Lan (Cambodia). Khoa-Hoc Dai-Hoc Duong (Fac. Sci.), 223-231, pls. 1-2, Saigon.

Schaub, H. (1963): Uber einige entowicklungsreichen von Nummulites und Assilina und ihres stratigraphishe bedeutung. In G. H. R. von KoENIGSWALD, J. D. EMEIS, W. L. BUNING and C. W. WAGNER (eds.): Evolutionary trends in foraminifera. Elsevier, Amsterdam, 283-297.

Sheng, J. C. (1956) : Permian Fusulinids from Liangshan, Hanchung, Southern Shensi. Acta Palaeont. Sinica, 4, 199-228, pls. 1-8.

(1963) : Permian Fusulinids of Kwangsi, Kueichow and Szechuan. Palaeont. Sinica, N. S., (10), 1-247, pls. 1-36.

Shrmizu, D. (1962): The Permian Mizuru Group, its stratigraphy and syntectonic succession through the Late Paleozoic orogeny. Mem. Coll. Sci. Univ. Kyoto, 28, 571-609.

Simpson, G. G. (1944) : Tempo and mode in evolution, 237 pp. Columbia Univ. Press, New York.

Skinner, J. W. and Wilde, G. L. (1954): Fusulinid wall structure. J. Paleont., 28, 445 , pls. $46-52$.

and - (1966): Permian Fusulinids from Pacific Northwest and Alaska. Univ. Kansas Paleont. Contr., Paper 4, 1-60, pls. 1-49.

SUYARI, K. (1961): Geological and paleontological studies in Central and Eastern Shikoku, Japan Part 1, Geology, Jour. Gakugei., Tokushima Univ., Nat., Sci., 11, 11-76.

Sylvester-Bradley, P. C. (1951): The subspecies in palaeontology. Geol. Mag., 88, 88-102.

(1956) : The species concept in palaeontology. Syst. Assoc., London, Pub. No. 2, $145 \mathrm{pp}$.

Thомas, G. (1956): The species conflict-Abstractions and their applicability. In P. C. Sylvester-Bradley (ed.) : The species concept in palaeontology, Syst. Assoc., London, 17-31.

Thompson, M. L. (1948): Studies of American Fusulinids. Univ. Kansas Palaeont. Contrib., Protozoa, Art. 1, 1-184, pls. 1-38.

(1964) : Fusulinacea. In R. C. Moone (ed.): Treatise on Invertebrate Paleontology, Part C, Protista 2. Geol. Soc. Amer. and Kansas Univ. Press. C358-436.

- and Wheeler, H. E. (1942): Permian Fusulinids from British Columbia, Washington and Oregon. J. Paleont., 16, 700-711, pls. 105-109.

TORIYAMA, R. (1942): The Fusulinids of the Yasuba conglomerate in the province of Tosa. Jap. Jour. Geol. Geogr., 18, 237-247, pls. 24-25. 
(1958) : Geology of Akiyoshi, Part 3. Fusulinids of Akiyoshi. Mem. Fac. Sci. Kyushu Univ., [D], 7, 1-264, pls. 1-48.

(1967) : Fusulinacean Zones of Japan. Ibid., 18, 35-260.

TRUEman, A. E. (1922): The use of Gryphaea in the correlation of the Lower Lias. Geol. Mag., 59, 256-268.

VAN der Vlerk, I. M. and Gloor, H. (1968): Evolution of an embryo. Genetica, 39, $45-63$.

Van Valen, L. (1968): "Gryphaea" evolution and natural selection. Evolution, 22, $424-425$.

VIEN, L. T. (1959): Etude de Fusulinides du Haut-Laos, du Cambodge et du Sud Viet-Nam. Ann. Fac. Sci. Saigon, 99-120, pls. 1-2.

YABe, H. (1948) : Neoschwagerininae DUNBAR and Condra. Proc. Acad. Tokyo, 24, 1-9. (1966) : Problems on the genus Lepidolina (Supplement). "Fossils" (Kaseki), Palaeont. Soc. Japan. (12), 47-55. (in Japanese)

Yamagiwa, N., IWahashi, T. and Habuchi, T. (1971) : Permian fusulinids from Idani district, Shimizu-machi, Arita-gun, Wakayama Prefecture, Southwest Japan. Mem. Osaka Kyoiku Univ., 20, 51-62, pl. 1.

and SAKA, Y. (1972): On the Lepidolina zone discovered from the Shima Peninsula, Southwest Japan. Trans. Proc. Palaeont. Soc. Japan, N. S., (85), 260-274, pls. 31-32. 